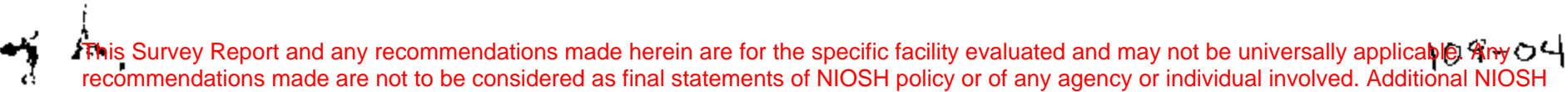
Survey Reports are available at http://www.cdc.gov/niosh/surveyreports.

FINAI REPORT

\title{
A SURVEY OF HEALTH HAZARD CONTROL SYSTEMS FOR MERCURY USE AND PROCESSING
}

Contract No. 210-81-7107

\author{
U.S. DEPARTMENT OF HEALTH AND HUMAN SERVICES \\ Publlc Healt h Service \\ Centers for Disease Control \\ National Inst 1tute for Occuparional \\ Safery and Healrh \\ Division of Phystcal Sciences and Englneering \\ 4676 Columbia Parkway \\ Cincinnat1, oh1o 45226
}

February 1984 


\section{DISCLAIMER}

The mention of company names or products does not constitute endorsement by the National Institute for occupational Safety and Health.

NIOSH Project officer:

Program Manager.

Princ1pal Investigators:
Alfred A. Amendola Dotlato R. Telesca Robert P. Reisdorf David $C$. D'Orlando 


\begin{abstract}
To document hazard controls in industrieg which use and process mercury, a study was conducted by NIOSH which surveyed methods used to control worker exposure to mercury. A total of 28 site visits were involved in the study and individual case study reports from these visits will be avallable from NTIS. Industries visited included battery manufacturing, temperaturesensing instrument manufacturing, fluorescent lamp manufacturing, electrical switch manufacturing processes using mercury, mercury chemical processing and production, and dentistry.

Results of this survey indicated that local exhaust ventilation, temperatire control, and work practices are all effective techniques for controlling mercury vapor. Also observed routinely in most sites visted were blological monitoring programs. In most cases, afrborne mercury vapor levels measured during the surveys were well below the OSHA PEL of 100 $\mathrm{ug} / \mathrm{m}^{3}$, and in some instances, the levels were below the NIosH recommended level of $50 \mathrm{ug} / \mathrm{m}^{3}$. Specific aspects of the various control methods studied are presented.
\end{abstract}


CONTENTS

DISCLATMER . . . . . . . . . . . . . . . . . . . . . . . . . . . 11

ABSTRACT . . . . . . . . . . . . . . . . . . . . . . . . . . . . 1ii

ACKNOWLEDGMENTS . . . . . . . . . . . . . . . . . . . . . . . . $\mathrm{x}$

I. INTRODJCTION . . . . . . . + . . . . . . . . . . . . . . . . . . . 1

II. SCOPE OF WORK , . . . . . . . . . . . . . . . . . . . . . . . . . 4

III. HEALTH HAZARDS IN INDUSTRIES USING INORGANIC MERCURY . . . . . . . 5

A. CHEMICAL AND PHYSICAL PROPERTIES OF MERCURY. . . . . . . . . . 5

B. WORKER EXPOSURE TO MERCURY . . . . . . . . . . . . . . . . . . 5

C. HEALTH EFFECTS OF MERCURY EXPOSURE . . . . . . . . . . . . . . 6

IV. MERCURY APPLICATIONS IN SPECIFIC INDUSTRIES . . . . . . . . . . . 8

A. BatTery MaNufacturing . . . . . . . . . . . . . . . . . . 8

1. Button Cells.............................. . 8

2. Zinc-Carbon Cells . . . . . . . . . . . . . . . . . . 9

3. Alkallne Cells . . . . . . . . . . . . . . . . . . . . . 9

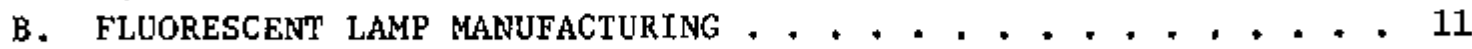

C. DENTISTRY . . . . . . . . . . . ................. 14

D. TEMPERATURR-SENSING INSTRUMENT MANUFACTURING . . . . . . . . . 16

1. Glass Thermoneter Manufacturing . . . . . . . . . . . . . 17

2. Thermal Sensing Element Manufacturing . . . . . . . . . . IT

E. ELECTRICAL SWITCH MANUFACTURING . . . . . . . . . . . . . . 20

1. Mercury SwItch for Thermostats. . . . . . . . . . . . . . 20

2. Mercury Buttons for Wall Swntches . . . . . . . . . . . 21

F . MERCURY USE IN ELECTRICAL PRDCESSES . + . . . . . . . . . . . 23

1. Chlor-Alkal1 . . . . . . . . . . . . . . . . . . . 23

2. Tungsten Bar Sintering........................ 26

3. Copper plating, . . . . . . . . . . . . . . . . 26

4. Electrical standard Calibration . . . . . . . . . . . 27

G. MERCURY CHEMICAL PROCESSING/MANUFACTURING . . . . . . . . . . 30

1. Mercury Ore (Cinnabar) Processing . . . . . . . . . . . 30

2. Mercury Retarting, Distilling, and Packaging . . . . . . 31

3. Mercury Compound Manufacturing . , . . . . . . . . , . 32

V. CONTROL METHODS. . . . . . . . . . . . . . . . . . . . . . . 36

A. ENGINEERING CONTROLS . . . . . . . . . . . . . . . . . . . 36

1. Process Substitution and Modification . . . . . . . . 36

a. Substitution for Mercury Electrical Contacts . . . . . 36

b. Dental Amalgam Handling Modiffcation , . . . . . 38

c. Particulate Handling Modification . . . . . . . . . 39

d. Modification $1 \mathrm{n}$ Mercury Processing. . . . . . . . . . 39

e. Modification In Mercury Filling Operations . . . . . . 41

2. Containment of Mercury Sources... . . . . . . . . . . . 44 4

a. Enclosed Systems for Liquid Mercury Transfer . . . . . 47

b. Enclosed Systens for Particulate Mercury Transfer. * . 49 
CONTENTS (Concinued)

c. Contanment of Mercury Products and Waates . . . . 50

d. Containment of Mercury Using Water and

Chemical Suppression............ 52

e. Removal of Mercury spills ............. 55

f. Containment of Mercury on Work Surfaces and Floors. 56

3 Ventilated Enclosure . . . . . . . . . . . . 57

a. Ventilated Enclosure of Process Equtpment . . . . 60

b. Ventilated Enclosure of Manufacturing Machinery . . 61

4. Local Exhaust Ventilation ............... 65

a. Work Station Exhaust Hoods............. 65

b. Equipment Exhausters............... 68

5. Temperature Control . . . . . . . . . . . . 72

6. D1lution Ventılation.............. 76

a. Dilution Ventilation Using Air Supply and

Exhaust Syatems .............. 78

b. Dilution Ventllation by Draft .......... 80

7. Isolation ........................ 81

8. Mercury Removal from Airstreams ............ 83

a. Removal of Mercury from Local Exhaust Airstreams . . 85

b. Removal of Mercury in Recixculating Ventilation

Systems ................. 85

B. BEHAVIORAL CONTROLS. . . . . . . . . . . . . . . . . 96

1. Housekeeping . . . . . . . . . . . . . . . . . 96

a. Mercury Decontaninants . . . . . . . . . . 96

b. Vacuum Cleaners . . . . . . . . . . . . 96

c. Palnting Floors .............. 102

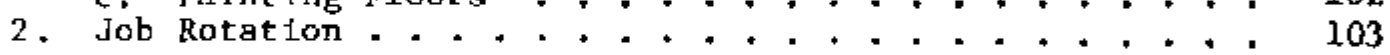

a. Preventive Job Rotation ............ 103

b. Work Shift Change ............. 103

3. Work Practices. . . . . . . . . . . . . . . 103

4. Personal Hygiene Practices.............. 104

5. Education and Training . . . . . . . . . . . . 104

c. PERSONAL PRO'CECTIVE EQUIPMENT AND CLOTHING . . . . . . . . 105

I. Resplrators .................. 105

a. Resplrator Descriptions ............ . 105

b. Resplrator Applications ............ 109

2. Other Protective Equipment . . . . . . . . . . . . 110

D. MONITORING CONTROL EFFECTIVENESS . . . . . . . . ... 111

1. Workplace Air Monitoring ................ 111

a. Mercury vapor Monitoring .. . . . . . . . . 111

b. Particulate Mercury Monitoring ........... 112

2 Bfological/Medical Monttoring . . . . . . . . 112

VI. CONCLUSIONS . . . . . . . . . . . . . . . . . . . 115

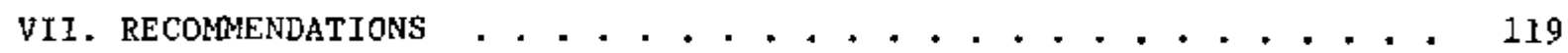

REFERENCES . . . . . . . . . . . . . . . . . . 121

APPENDIX . . . . . . . . . . . . ...... 122 
I-1 Projected U.S. Mercury Demand by End Use for 1985 . . . . . 2

IV-1 Workplace Alr Concentrations of Mercury in Three Battery Manufacturing Facilities . . . . . . . . . . 10

IV-2 Mercury Emission Sources and Control Methods for Battery Manufacturing. . . . . . . . . . . . . 11

IV-3 Workplace Air Concentrations of Mercury in a Fluorescent Lamp Manufacturing Plant . . . . . . . . . 13

IV-4 Mercury Emission Sources and Control Methods for the Fluorescent Lamp Manufacturing Industry . . . . . . . 14

IV-5 Workplace Air Concentrations of Mercury in Two Dental Clinics ................... 15

IV-6 Mercury Emission Sources and Control Methods for the Dental Tndustry.................... 16

IV-7 Workplace Air Concentrations of Mexeury in Two Thermometer Manufacturing Plants . . . . . . . . . . .

IV-8 Mercury Enisston Sources and Control Methods for the Thermometer Manufacturing Industry ......... 20

IV-9 Workplace Alr Concentrations of Mercury in Two Electrical Swltch Manufacturing Plants . . . . . . . . 22

IV-10 Mercury Enission Sources and Control Methods for the Electrical switch Indugtry ............. 23

IV-1I Workplace Air Concentrations of Mercury in a ChlorAlkali Plant . . . . . . . . . . . . . . . 25

IV-12 Workplace Alx Concentrations of Mercury in a Copper Plat.tng Plant.................. 27

IV-13 Mercury Emission Sources and Control Methods for Electrical Processes................ 29

IV-14 Workplace Atr Concentrations of Mercury in a Cinnabar Processing Plant ................. . 31

IV-15 Workplace Air Concentrations of Mercury in a Mercury Processing Plant .................. 32 
IV-16 Workplace Air Concentrations of Mercury in a Phenylmercuric Acetate Manufacturing plant ........ . 34

IV-17 Mercury Emission Sources and Control Methods for Mercury Chemical Production. . . . . . . . . . . . . . . 35

V-1 Summary of Major "Process Substitution and Modification" Controls . . . . . . . . . . . . . . . . 45

V-2 Sumnary of Major "Containment" Controls . . . . . . . + . 58

V-3 Summary of "Ventilated Enclosures" Controls . . . . . . . . 66

V-4 Summary of "Local Exhaust Ventilation"

Controls ............................. 73

V-5 Temperature Effect on Nercury Vapor Pressure * . * * . . * * 75

v-6 Sumary of "Temperature" Controls . . . . . . . . . . . . 77

V-7 Sumary of "Dilution Ventilation" Controls . . . . . . . . 82

V-8 Summary of "Tsolat ton" Controls . . . . . . . . . . . . . . 84

V-9 Summary of "Mercury Removal from Alrstream" Controls . . . . . . . . . . . . . . . . . 95

v-10 Summary of Behavioral Practices Implemented to Reduce Mercury Exposure . . . . . . . . . . . . . . . . . 97

v-1l Summary of Mercury Decontaminant Applfcations . . . . . . . 102

y-12 Sumary of Personal Protective Equipment Used... . . . . 106

v-13 Summary of Respirators . . . . . . . . . . . . . . . . 109

V-14 Mercury Exposure Limits and Required Action for the State of Massachusetts . . . . . . . . . . . . . . . 113

V-15 Mercury Exposure Limits for the State of Callfornia . . . . 113 
IV-1 Temperature Sensing Instrument .............. 18

IV-2 Typical Chlor-Alkali Cell . . . . . . . . . . . . . 24

IV-3 Typlcal Electrical standard . . . . . . . . . . . . 28

V-1 TWLCO Roto-Grounds Mounted on a Rotating Shaft . . . . . . 37

V-2 Dispersalloy ${ }^{\mathrm{R}}$ Dispos-a-cap Components ........... 40

v-3 Mount Assembly with Mercury Pill . . . . . . . . . . . 42

V-4 Exhaust Tube Tip Concainer ............... . 43

V-5 Schematic Diagram of the Mercury Filler . . . . . . . . 46

v-6 Mercury Storage Container ................ 48

v-7 Material Transfer Contalner . . . . . . . . . . . 51

V-8 Inlet Box with Lid Open Showlng Waterflow . . . . . . . 53

V-9 Mercury Vapor Levels, Heads (Concentrate Production),
and Tailing Production as a Function of Na 2 S Adition . * 54

V-10 Plextglas Machine Enclogure .............. 62

v-11 Glove Box ................................ 63

v-12 Mercury fill station Hood . . . . . . . . . . . . 64

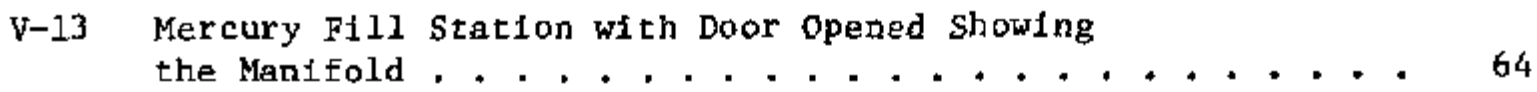

V-14 Mylar Sheet Across the Face of the Exhaust Hood . . . . . 67

v-15 Shroud Over Exhaust Machlne . . . . . . . . . . . 69

V-16 Exhaust AIX Takeoff at Drum Loading Stand . . . . . . . . 69

V-17 Filter Bag for Removing PMA from Exhaust A1r . . . . . . 70

V-18 Mercuric oxide Charger tood Design . . . . . . . . . . 71

v-19 Schematic Drawing of Drum Loading Hood . . . . . . . . 72 


\section{FIGURES (continued)}

Page

v-20 Local Fresh Air Supply . . . . . . . . . . . . . . 79

v-2l Adjustable 2-1nch supply A1r vents . . . . . . . 80

v-22 Air Treatment Systen for Mercury Removal . . . . . . . 86

v-23 Schematic of Recirculating A1r Sygtem . . . . . . . 88

v-24 Fiber Filters for Particulate Removal . . . . . . . 89

V-25 Orfginal and Modffied Air Handler Configurations . . . . 91

v-26 Charcoal F1lter Rack Configuration ............. 92

v-27 Torit Dust Collection Unit ............... 93

VI-1 Work Station with Dralnage Trough ............. 118

VI-2 Ventllated Work Station With Grated Surface . . . . . . 118 


\section{ACKNOWLEDGMENTS}

The Division of Phyaical Sclences and Englneerlag, National Institute for Occupational Safety and Heaith, supported this contral system survey for mercury use and processing. Alfred A. Amendola, NIosH Project officer, partictpated in this study and worked closely with Donato R. Telesca, Program Manager, in the evolution of this report. The principal investigators responsible for collecting, analyzing, and reporting the information for thia study were Robert $P$. Refsdorf and David C. D'Orlando.

The 1nterest and cooperation of the mercury-using industrieg made this study possible. The manuscript was patiently and ably typed by Ms. Stella Lenta. 


\section{INTRODUCTION}

Control technology is being developed and implemented in response to increased awareness of the need to prevent occupational exposure to hazardous materials. The National Institute for Occupational Safety and Health (NIOSH) is involved in studying and promoting the development of control technology that is effective in reducing occupattonal hazards. Since 1976, NTOSH has sponsored control technology assessments in the plastlcs and resins industry, primary and secondary smelting operations, foundries, pestictdes manufacturing, drycleaning operations, tire manufacturing, raw cotcon processing, pulp and paper processing, coal converston procesges, and other processes, The primary objectlve of these studieg is to assist industry in improving worker protection, particularly when problems arise of when new health standards are promulgated.

Increased interest in the health effects resulting from exposure to mercury and mercury compounds led to the decision to survey the controls currently in use to reduce this exposure. The current accupational Safety and Health Admintstration (OSHA) permissible exposure $11 \mathrm{mit}$ (PEL) $1 \mathrm{~s} 0.1 \mathrm{mg} / \mathrm{m}^{3}$ as an 8-hour time-weighted average (TWA). NIOSH recomends that the TWA exposure limlt be reduced to $0.05 \mathrm{mg} / \mathrm{m}^{3}$. The American Conference of Governmental Industrial Hygtentsts (ACGIH) bas recommended a Threshold Linft Value (TLV) of $0.05 \mathrm{mg} / \mathrm{m}^{3}$ as an 8 -hour TWA for all forms of mercury except alkyl, and 0.01 agg $/ \mathrm{m}^{3}$ for alkyl compounds.

Major industrles and activities in which mercury is used as a raw material or as a means of production include battery manufacturing, thermometer manufacturing, mercury switch manufacturing, fluorescent lamp manufacturing, chlor-alkali production, electroplating, wetal aintering, electrical standards wanufacturing, bactericide/fungicide manufacturing, catalyst manufacturing, pharmaceutical manufacturing, paint manufacturlag, mercury processing, and dentistry. (Dentistry, for the purpose of this study, is also regarded as an industry.)

The material presented in this document is a compilation of information gathered from 28 site visits to 24 facilities. The number of aite vialts conducted in each industry were:

$\begin{array}{ll}\text { Battery Manufacturing } & 5 \\ \text { Temperature-Sensing Instrument Manufacturing } & 5 \\ \text { Fluorescent Lamp Manufacturing } & 3 \\ \text { Electrical Switch Manufacturing } & 2 \\ \text { Electrical Processes Ustng Mercury } & 5 \\ \text { Mercury Chemical Processing/Production } & 6 \\ \text { Dentistry } & 2\end{array}$

These sites were selected on the basts of good, transferable control concepts and practices. They do not, therefore, constitute a randomly selected sample of mercury-1sing industries, and conclusions regarding the general extent of exposure to mercury should not be drawn from thit study. 
In addition to the data gathered from 1ndustry, information on biological monitoring prograns was obtained from Leonard Goldwater, M.D., of the Duke Medical Center. A text of this discussion is avallable from NIOSH.

Projected usage for the year 1985 (Table $I-1$ ) ahows that over 82 percent of the total U.S. mercury demand will be from four industrfal sectors: the chloralkali, dental, electrical equipment, and industrial instruments industries.

TABLE I-1

Projected U.S, Mercury Demand by End Use for 1985

\begin{tabular}{lcc}
\multicolumn{1}{c}{ Industrial Sector } & $\begin{array}{c}\text { Amount } \\
\text { (metric tons) }\end{array}$ & Percent of Total \\
\hline $\begin{array}{l}\text { Chlor-alkalf } \\
\text { Dental }\end{array}$ & $482 *$ & 23 \\
$\begin{array}{l}\text { Electrical Equipment } \\
\text { (includes battery lamps) }\end{array}$ & 129 & 6 \\
$\begin{array}{l}\text { Industrial Instruments } \\
\text { (1ncludes swatches and thermometers) } \\
\begin{array}{l}\text { Other } \\
\text { Total }\end{array}\end{array}$ & 662 & 21 \\
\hline
\end{tabular}

*This amount may be affected by the development of new technologies

in chlor-a1kali manufactur \pm ng.

Source: Bureau of Mines, 1980.

This survey is designed to identify and assess control methods used in mercury-using industries for reducing worker exposure to inorganic mercury. The information will help provide an information source for (1) new plants designing a mercury control strategy and (2) existing factlities attempting to reduce exposure to mercury through the improvement of current controls or the implementation of new controls. Information is presented to assist a company or organization in selecting a control scheme according to its specific needs. Possible control l1mitations and disadvantages are also presented, to help industries avoid the Installation of ineffective control systems. A level of detall is presented such that a competent designer could use the concepts and practices described as a source of data to help implement effective controls. The report is not intended to supplant the bastc destgn and englneering skfls which are necessary to translate controls from one specific context to another one, however, nor is it likely that all available controls are included in the report. 
This report is intended to be a useful tool for industrfal hygtentsts, plant engineers and managers, and labor organizations. It describes potential problems assoclated with the use of mercury in 1ndustry, and presents some control methods available to avold these problems. The document is presented in three major sectlons

Health Ilazards in Industries Using Inorganic Mercury This section introduces the reader to the health effects in humans from exposure to different forms of mercury. It also describes biochemical. mechanisms by which the mercury interacts with the human body.

Mercury Applications in Specific Industries

This section describes the role of mercury in seven dffferent industries. Generic process descriptions are presented along with data on typlcal airborne mercury concentrations assoctated with the untt operations of the processes. The potential mercury vapor, liquid mercury, and mercury particulate emission sources are presented in a motrlx with the generic control methods typlcally used to control these entssions.

Control Methods

This section documents the contrals used to reduce worker exposure to mercury and 1 ts compounds. The methods applied to control the entssion sources and dispersion of mercury discussed in the previous section are described in more detail. These control methods are presented in the recommended order of approach that an organization should take to reduce worker exposure. Some possible advantages and disadvantages of the speciflc controls are listed atong whth the potential applications in other 1ndustries. Also included in this section are the personal protectlve equipment, work practices and training, and air monitoring methods employed in achieving and documenting reduced worker exposure to mercury.

The final section of the report outlines conclusions and recommendations for further study of mercury controls and new applications for existing controls.

The Information generated in this study is the result of onsite surveys conducted at various mercury-using facilities. Additional or more detalled Information on the controls studied 1 s contained in the individual site visit reports, which may be obtafned on a limlted basis from the Engineering Control Technology Branch of the National Institute for Occupational Safety and Health, Division of Physical Sczences and Eng1neer1ng, 4676 Columb1a Parkway, Cincinnati, Ohio 45226. These reports will be placed in the National Technical Information Service (NTIS) in the near future, and requests should be directed to this data base as a princlpal source for these reports. 


\section{SCOPE OF WORK}

For this study, mercury is defined as elemental mercury, 1norganic metcury compounds, and organic mercury compounds other than ethyl or methyl mercury.

The purpose of this study is to.

- document methods used in controlling worker exposure to mercury

- estimate the effectiveness of these methods of control

o describe controls that are in the planning stages at factlities surveyed.

The control methods within the scope of this study are:

Englneertng controls - elimination by substitution, equipment design changes, devices to control hazardous emissions, process modification, tsolation of the worker, isolation of equipment, and plant design.

Personal protective equipment - resplrators and protective clathing worn by workers to reduce physical contact w1th mercury.

Work practices - procedures prescribed by management to reduce worker exposure to mercury.

Monitoring programs - the determination of control effectiveness and actual worker exposure through air sampling and biological monitoring.

The investigation of mercury controls was conducted during preliminary and 1n-depth surveys. Preliminary surveys were made to determine the controls that warranted additional Investigation. Information on these controls was obtained during in-depth surveys that 1ncluded control dacumentation and air sampling to help determine contral effectiveness.

Selection of plants for surveys was based on literature seaxch, chemlcal inventory search, information obtained from academic experts and union contacts, and discussions with plant representatives. 


\section{HEALTH HAZARDS IN INDUSTRIES USING INORGANIC MERCURY}

\section{A. CHEMTCAL AND PHYSICAL, PROPERTIES OF MERCURY}

The primary source of mercury is cinnabar ore. Its chemical symbol is $\mathrm{hg}$ from the Greek word, hydrargyros, "water silver". Mercury is a sllvery, mobile liquid at room temperature which explains its synonyn, quicksilver. Its molecular weight is 200.6 , boiling point (760 mm $\mathrm{Hg}$ ) is $357^{\circ} \mathrm{C}\left(674^{\circ} \mathrm{F}\right)$, spectfic gravity (water $=1$ ) is 13.55 , melting point is $-39^{\circ} \mathrm{C}$ ( $-38^{\circ} \mathrm{F}$ ), vapor pressure at $20^{\circ} \mathrm{C}\left(68^{\circ} \mathrm{F}\right)$ is $0.0012 \mathrm{~mm} \mathrm{Hg}$, and solubility in water $(\mathrm{g} / 100 \mathrm{~g}$ water at $20^{\circ} \mathrm{C}\left(68^{\circ} \mathrm{F}\right)$ ) is 0.002 Mercury is a good conductor of electricity and has coefficient of cublcal expansion of 181.86 at $20^{\circ} \mathrm{C}\left(68^{\circ} \mathrm{F}\right.$ ). Metals, other than iron and platinum, will dissolve in mercury. Mercury is not combustible, but when in contact with acetylene, acetylene products, or ammonia gases may form solid products that are sensitive to shock and can initiate fires of combustible materials. Mercury is odorless and has no warning properties.

\section{B. WORKER EXPOSURE TO MERCURY}

The primary route of exposure to mercury in the workplace is by the inhalation of vapor or particulate mercury. Mercury may also be introduced into the body through dermal absorption and ingestion.

The spread of mercury (partfcularly the elemental form) from contaminated hands to other parts of the body (including hatr and clothing) may increase inhalation exposure to mercury vapor by creating a "microenvironmental exposure" (Stopford et al. 1978). A characterist1c of th1s microenvironment is that mercury vapor 1s usually present at higher concentrations in the breathIng zone of the worker than in the surrounding workplace air. Consequently, when determining worker exposure, performing only area monttoring may not provide an accurate indication of exposure. In addition, comparison of area values with the Threshold Limit Value (TLV) or PEL for mercury may provide a false indication of safe exposure.

The physical properties of mercury may make identification of sources of worker exposure difficult. For example, elemental and particulate mercury can be carried throughout a factlity on workers' shoes and clothing and may be subsequently deposfted on walkways, stalrs, and floors. Mercury may also concentrate $1 \mathrm{n}$ cracks and crevices, especlally in untreated wood and uncoated cement surfaces. Once dispersed throughout a plant or concentrated in cracks, elemental mercury, and to some extent inorgantc salts of mercury, continues to vaporize into the workplace. Consequently, when evaluating exposure at a facility, all of these factors, as well as the industrial process beling evaluated, must be considered. 


\section{HEALTH EFFECTS OF MERCURY EXPOSURE}

Toxtc effects of chemcal agents depend on the exposure sttuation (route of administration and the duration and frequency of exposure), the susceptibility of the subject (age, sex, etc.), and the chemical and physical properties of the agent. In the case of mercury, the chemlcal form to which the worker is exposed is particularly tmportant. The following forms of mercury are commonly used in industry

- elemental mercury

- Inorgante mercury compounds

o organıc mercury--a diverse group of compounds Including alkyl, alkoxyalkyl, and phenyl mercurfal compounds. (Coverage in this report is limited to the nonalkyl mercurlal compounds.)

Inhalation exposure is a primary concern when working with elemental mercury (Hg). The vapor pressure and high lipld solubllity of mercury allows it to be readily retained and absorbed tn the lungs. Conversely, absorption from the gastrontestinal tract is very poor and normally does not contribute appreciably to occupational exposure (Hammond and Beliles 1980).

Examples of inorgantc mercurial compounds commonly found in induatry for which control information is presented in this report include:

- Mercuric oxtde (HgO)--a red or yellow, water-insoluble powder. The finer particles ( 5 micrometers) appear yellow, and the larger particles are reddish. It is an important materfal in the battery Industry.

- Mercuric sulfide (HgS)--a red, water-1nsaluble materlal that reacts with oxygen at low heat to produce metallic mercury and $\mathrm{SO}_{2}$.

- Mercuric chloride $\left(\mathrm{HgCl}_{2}\right)$-wa highly tox1c, water-saluble powder or crystaline substance, used in the preparation of mercurfc oxide.

The basic biochemical mecharism whereby frargantc mercury compounds produce adverse health effects is not completely understood. However, the1r toxicity appears to depend on their dissociation capabllity in body fluids with all compounds probably acting by a single basic mechanism. The primary mode of action may be the association of $\mathrm{Hg}^{+}$with membrane permeability and metabollc enzyme systems via binding to essential sulfhydryl groups, thus diarupting enzyme activity. Chronic mercury polsoning due to continued excessive exposure compounds may result in kidney damage (Hammond and Beliles 1980). 
Phenylmercuric acetate (PMA) is a common phenyl mercurial for which control information is presented in this report. PMA 1s a highly irritating white crystalline materlal that is silghtly volatile at room temperature, slightly saluble in water, and readily soluble in alcohol. Ilke other members of its class, the readily biodegradable PMA reacts in the body with sulfhydryl groups, thus interferung with essential cellular function. The toxic activity of thege chemicals is essentially the same as that described for the fnorganic mercurial chemcals ( $1, \mathrm{e}_{*}$, the action of the $\mathrm{Hg}^{++}$cation).

Acute exposure to mercury at high levels causes severe respiratory irritation, dtgestive disturbances, and marked renal damage; chronic mercurialism, the form of intoxication most frequently caused by occupational exposure, is characterized by neurologic and psychic disturbances, anorexia, weight loss, and stomatitis. Skin absorption of inorganic mercury probably adds to the toxic effects of vapor inhalation. Intraperltoneal injection of metallic mercury in rats has produced sarcomas. Exposure of humans to mercury vapor in concentrations of 1.2 to $8.5 \mathrm{mg} / \mathrm{m}^{3}$ causes cough, chest pain, and dyspnea, leading to branchitis and pneumonitis. At low levels, the onset of symptoms resulting from chronic exposure is insidious, fine tremors of the hands, eyelids, lips, and tongue are often the presenting compla1nt. Coarse jerky movements and incoordination may interfere with the fine movements considered necessary for writing and eating. Psychic disturbances such as insomia, Irritability, and indectsion occur, headache, excessive fatigue, anorexia, digestive disturbances, and weight loss are comon, atomatitis with excessive salivation $1 s$ sometimes severe, muscle weakness has been reported. Proteinuria may occur, but is relatively infrequent. Mercury has been reported to be capable of causing sensitization dermititis.

The OSHA PEL for mercury is based on the observation that as the concentration of mercury vapor increases to approximately $0.1 \mathrm{mg} / \mathrm{m}^{3}$, the frequency of the neuropsychiatric symptoms among workers increases significantly. The NIOSH-recommended $1 \mathrm{Im} t$ of $0.05 \mathrm{mg} / \mathrm{m}^{3}$ was selected based on evidence of toxicity at concentrations below $0.1 \mathrm{mg} / \mathrm{m}^{3}$ (NIOSH 1973). 


\section{MERCURY APPLICATIONS IN SPECIFIC INDUSTRIES}

Generlc descriptions of the metcury applications studied are presented in this section Each description is followed by a matrix of potential mercury emissions and the control methods used to reduce worker exposure. Workplace air concentrations of mercury, which were determined during some onsite surveys, are a1so presented.

\section{A. BATTERY MANUFACTURING}

Mercury and mercury compounds are used in the manufacture of button, zinc-carbon, and alkaline cells.

\section{Button Cells}

A typical button cell, comonly used to power digital watches and hearing alds, consists of a cathode, anode, electrolyte, insulatora, and a containfng can. Both the cathode and anode contafn mercury.

a. Cathode Production

The cathode is a pellet consusting of a mixture of mercurtc oxide, cadmium, and graphlte. These powdered components are elther added manually or metered through a hopper to a $V$-blender or planetary mixer. After blending, the mixture is densified using a process called "slugging" in which the mixture is compacted into tablets by an enclosed rotary pressing device. The tableta are then ground tnto uniformb sized particles and are pelletized to a specified size and denstry using a rotary press. Materials transfer from mixing to pelletization is by closed hoppers. Pellets are consolidated into small metal cans ( 0.5 inch in diameter) in preparation for assembly.

b. Anode Production

The anode is a zincmercury amalgam produced by blending zinc powder with elemental mercury. Components are metered into an enclosed blender from hoppers or hold tanks. The resulting amalgam, which 15 dried and acreened to produce unf formly sized particles, is used in powdered or tablet form. Tablets are made by pelletizing the amalgam in a rotary press.

c. Gell Assembly

Assembly of the mercury cells is performed on either an automatic or semiautomatic process 11ne. The cathode (can and pellet), anode (powder or tablet), electrolyte, and a top cover are assembled and sealed with a crimper, Other components, such as an insulator, an absorber, and a barrier, are added to the cell as required by design specifications. 
a. Cathode Production

Zinc-carbon cells contain an electrolyte produced by mixing mercurlc chlor1 de powder with a zine chloride solution. Mercuric chloride is added to the solution manualiy. The electrolyte is blended into a dry cathode base mix consisting of zinc oxide and uther proprletary components. The resulting maist cathode base mix has a conststency simflar to brown sugar.

b. Cell Assemb1y

The cathode mix, which is transferred to a cell assembly area, is injected into paper-lined zinc cans. Mercury in the $\mathrm{mlx}$ migrates through the paper Ifniag and amalgamates with the zinc can, Berving as a corrosion inbibitor. A carbon penctl (anode) is pressed through the center of the mixture, and a support washer is placed inside the can to contain the mixture. Asphalt 1s used to seal the cell, and a metal cap is added to the top of the can. The top of the can is crimped closed around the metal cap, completing the cell assembly.

\section{Alkaline Cells}

Alkaline cells are made with an anode gel contalning zinc-mercury amalgam and a cathode consisting of manganese dioxtde and graphite. Mercury is used to suppress the generation of gas $1 n$ the cell and to improve the discharge rate.

a Anode Production

Anode gel is produced by mixing zinc oxide, liquid mercury, an electrolyte solution, and a gelling agent in a large blender. The blender is operated under vacuum.

After blending, the gel is allowed to stand for a specified time, is manually fed into a grinder to eliminate lumps, and then is transported to a cell assembly area.

b. Ce11 Assembly

The cell assemlity process begins with the insertion of a preformed cathode (an annlar, compacted mixture of manganese dioxide and graphite) into a steel can. A paper cylinder is inserted in the cathode along with a specified amount of electrolyte solution, and the anode gel is dispensed manually or dutomaticaliy inside the cylinder. Current collectors are placed on top of the cell, the can is crimped closed, and the completed cell is enclosed in a battery casing.

Sampling Results, Emission Sources, and Concrol Methods The results of sampling at three battery manufacturing plants surveyed are presented in Table IV-1. As this table shows mercury workplace area samples were below the OSHA PEL and NIOSH recommended level in most of the battery manufacturing process areas visited during the surveys, with two exceptions. (1) button cell cathode production areas; where mercury particulate concentrations 1 n both siugging and consolidation operations typically averaged greater than the PEL, and (2) alkaline cell anode (amalgam/gel) production areas, where mercury vapor concentrations, as reported by the manufacturers, may exceed the PEL. 
TABLE TV-1

Workplace Atr Concentratlons of Mercury

in Three Battery lianufacturing Facilities

\begin{tabular}{|c|c|c|c|c|c|}
\hline $\begin{array}{l}\text { AREA SAFPIES } \\
\text { Samp le Locat } 10 \text { n }\end{array}$ & $\begin{array}{l}\text { Type of } \\
\text { Samp Te }\end{array}$ & $\begin{array}{c}\text { Mercury Vavur } \\
\text { Concentration }\left\{\mathrm{mg}^{3} \mathrm{~m}^{3}\right\} \\
\text { Range }\end{array}$ & $\begin{array}{l}\text { Type of } \\
\text { Sample }\end{array}$ & $\begin{array}{l}\text { Part 1culate Mercury } \\
\text { Concentration }\left\{\frac{[\mathrm{mg} / \mathrm{m}}{3}\right) \\
\text { Range }\end{array}$ & Comnents \\
\hline $\begin{array}{l}\text { Outton Cells } \\
\text { Cathode production } \\
\text { slugging } \\
\text { Cathade product ion } \\
\text { consolidation } \\
\text { Ce } 11 \text { assemhly }\end{array}$ & 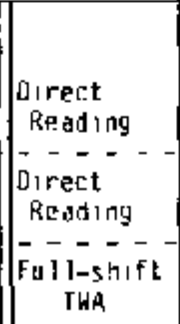 & $\left\{\begin{array}{cc}0020-0100(12)^{1} & 0062 \\
0040-0050(5) & 0045 \\
0011-0041(4) & 0024\end{array}\right.$ & $\begin{array}{l}\text { Full -shift } \\
\text { TWA } \\
\text { Fulli-shift } \\
\text { TWA } \\
\text { Full-shitt } \\
\text { IWA }\end{array}$ & 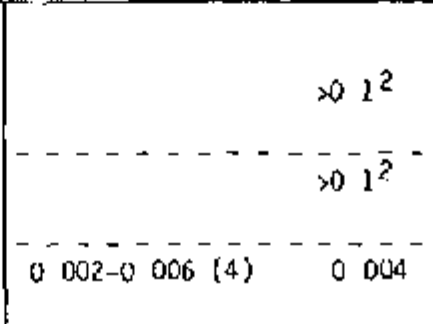 & $\begin{array}{l}\text { Full-time use of respirators } \\
\text { required } \\
\text { Full-time use of respirators } \\
\text { required }\end{array}$ \\
\hline $\begin{array}{l}\text { Zunc-Carbon Celis } \\
\text { Cathode mixing } \\
\text { Ce-11 assembly }\end{array}$ & ---7 & $\left\{\begin{array}{l}\operatorname{NM}^{3} \\
--2 \\
\operatorname{NM}^{3}\end{array}\right.$ & $\begin{array}{l}\text { Ful1-snift } \\
\text { TWA } \\
\text { Full-shift } \\
\text { TWA }\end{array}$ & $\left\{\begin{array}{l}40002-0005(2) \quad 0003^{4} \\
-0.002-0003(2) \\
0002\end{array}\right.$ & $--\ldots--\cdots+-\ldots-$ \\
\hline $\begin{array}{l}\text { Alkaline Cel1s } \\
\text { anode production } \\
\text { gel preparation }\end{array}$ & 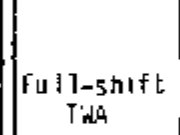 & $>01^{2}$ & & MM & $\begin{array}{l}\text { Full-tine use of respirators } \\
\text { required }\end{array}$ \\
\hline
\end{tabular}

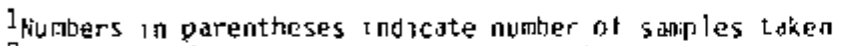

2 gased on inforindtion supplied by che piant

3 Nat measured, however, not expected to be a 51 gnif ic ant hazard under existing conditions.

${ }^{4}$ lawer 1 init of detection used in calculating mean concentrations 
Typical emission sources and the methods used to control them are presented in Table IV 2 .

TABLE IV -2

Mercury Em.Ssion Sources and Control Methods for Battery Manufacturing

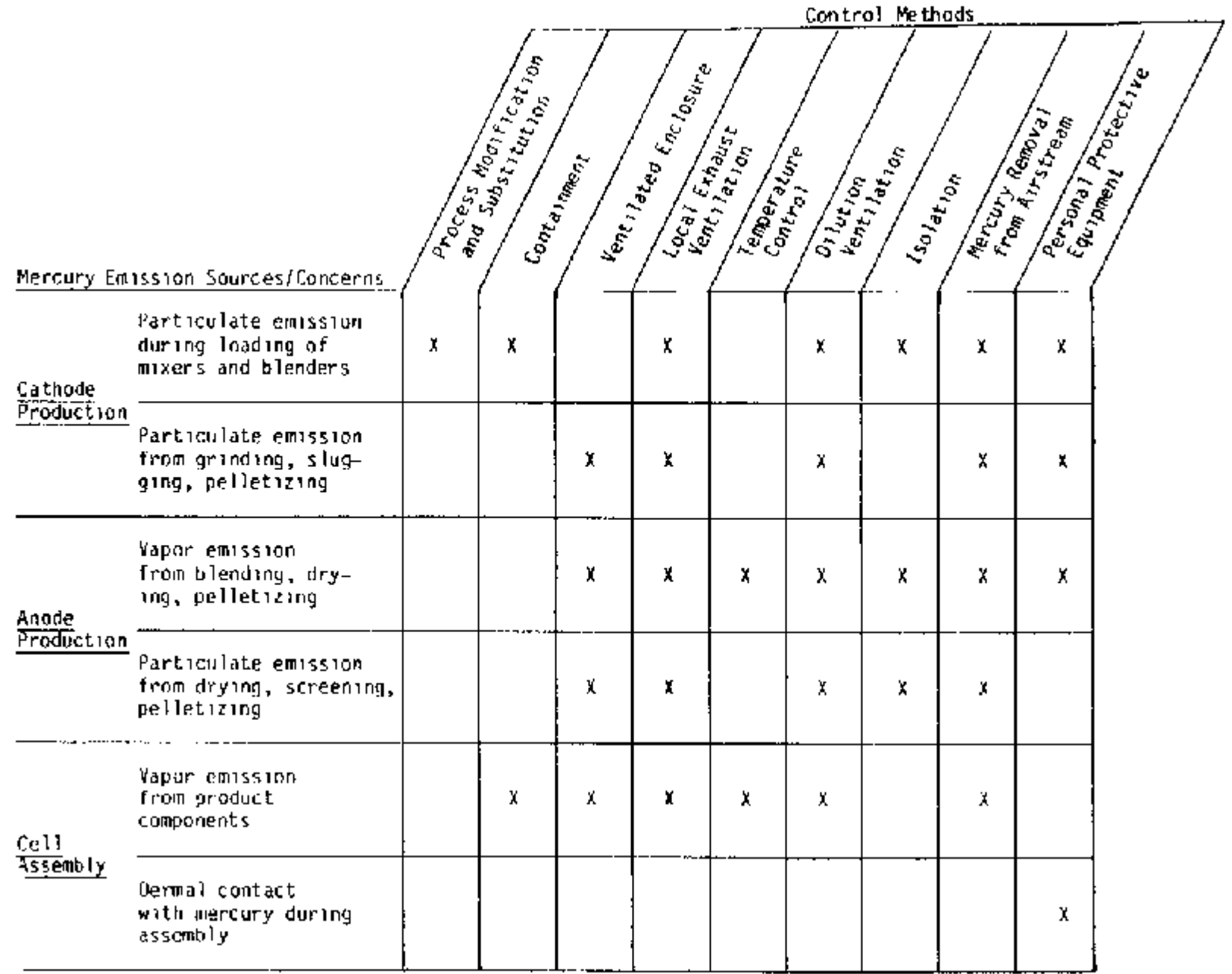

\section{B. FLUORESCENT LAMP MANUPACTURING}

Elemental mercury is used in manufacturing fluorescent lamps. The production of the lamps begins with the preparation of the lamp tube. Precut glass tubes are loaded onto a coating machine. The tubes are washed to remove impurities, dried with hot air, and coated with a liquid phosphor emulsion that deposits a film on the inside of the tube. Additives in the coating are removed by passing the tubes through an oven. This results in a thin layer of dry phosphor compound on the instde of each tube. 
Mount assemblies are fused to each end of the glass tube. Each assembly contsists of a funnel-shaped plece of glass with an "exhaust tube" through the center, lead wires, and a splral-wound "hot cathode" wire (tungsten coll).

A small amount of mercury ( $15-250 \mathrm{mg}$ ) is injected tito the lamp tube on an exhaust machine. The exhaust machine 18 a multistationed unit in which lamp tubes are exhausted, mercury $1 \mathrm{~s}$ added, and the tubes are sealed. The mercury is added to the lamp using a piston-type doser. The plston in the doser $2 \mathrm{~s}$ inted into a mercury reservorr (by an electrowagnet) where it receives a mercury dose. The plston then falls to deliver the dose through the exhaust tube into the lamp tube. A vacuum is then drawn to exhaust the tube and the tube is filled with inert gas. The open exhaust tube is sealed cloged snd tipped off. Exhaust tube tips are discarded in a waste container, and the lamp tube is removed from the exhaust machine.

Following the sealing of the tubes, metal baseg are attached to the ends of the lamp and cemented in place by heating. As a process check, current is applied to the lamp contacts to light the lamp. The final gtep is the application of a silicone coating to the outside of the tube to prevent moisture from accumulating on the lamp.

Elemental mercury, used for filling the lamp tubes, fo oxified and filtered before it is put through the mercury-fllling process. An oxifier is a sealed chamber that contalns two stainless steel, wheel-shaped agitators. Mercury is poured into the chamber, which is then sealed. Air is pumped Into the chamber and the agitators are started. The air oxidizes the contaninants in the mercury, causling them to float and separate out after agitation. After approximately 4 hours of agitation, the mercury ig dratned from the oxyfier and is filtered.

Sampling Results, Enission Sources, and Control Methods A1 5 sampling results from a fluorescent lamp manufacturing plant surveyed are presented in Table IV-3. Two methods of mercury filling are used at this plant. Typlcal emission sources and the methods used to control them are presented in Table IV-4.

Worker exposure to mercury vapor at the plant was generally below the OSHA PEL during the survey. The difference between the personal and area concentrations at the mercury addition areas are significantly lower at the 95\% confidence level in Process $B$, which used an enclosed mercury "pill" process of dosing lanps, as compared to the conventional doser exhaust mach1nes used in Process $A$. 
TABLE IV-3

Workplace Air Concentrations of Mercury in a Fluorescent Lamp Manufacturing Plant

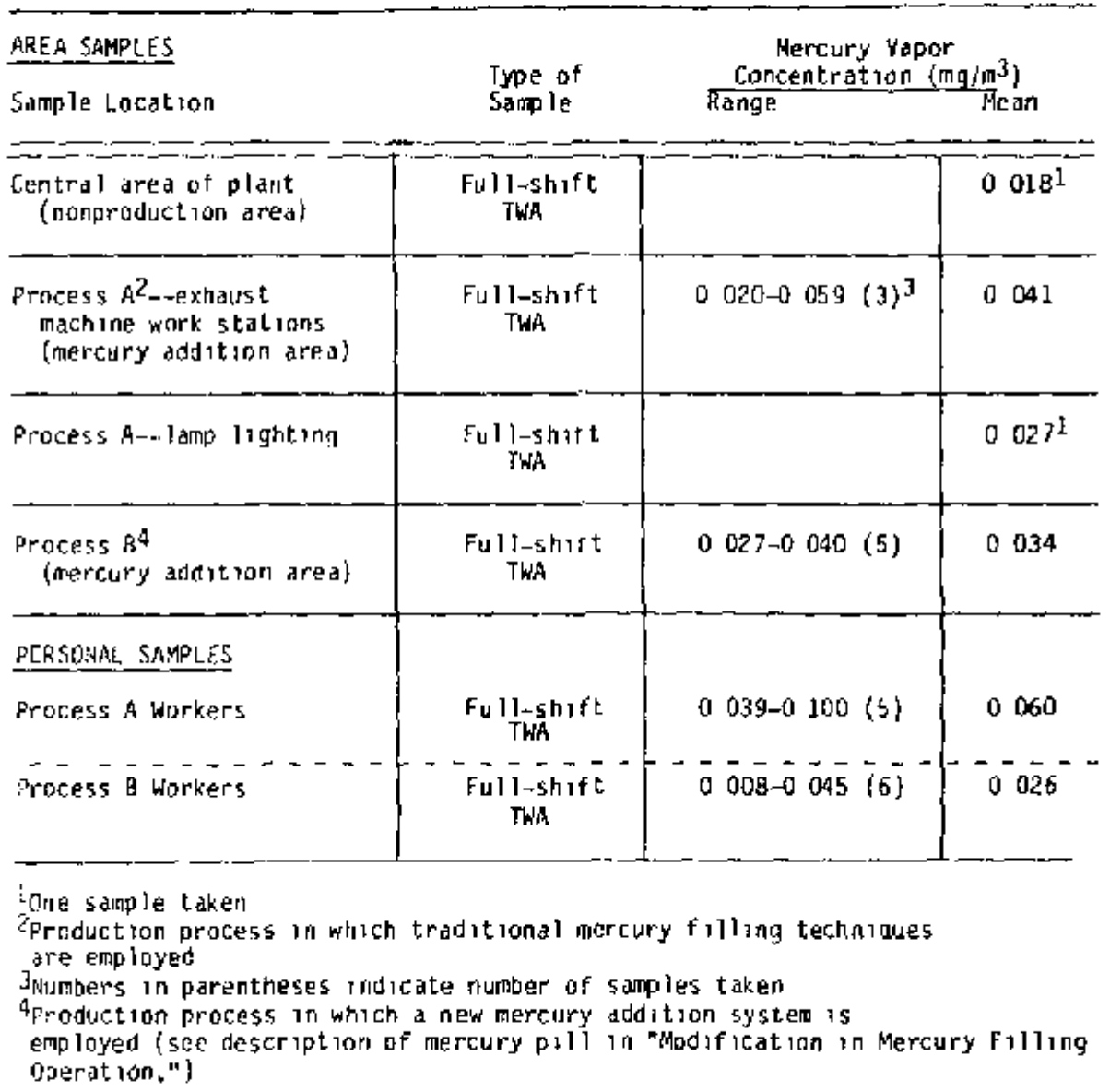


Mercury Emission Sources and Control Methods for the Fluorescent Lamp Manufacturing Industry

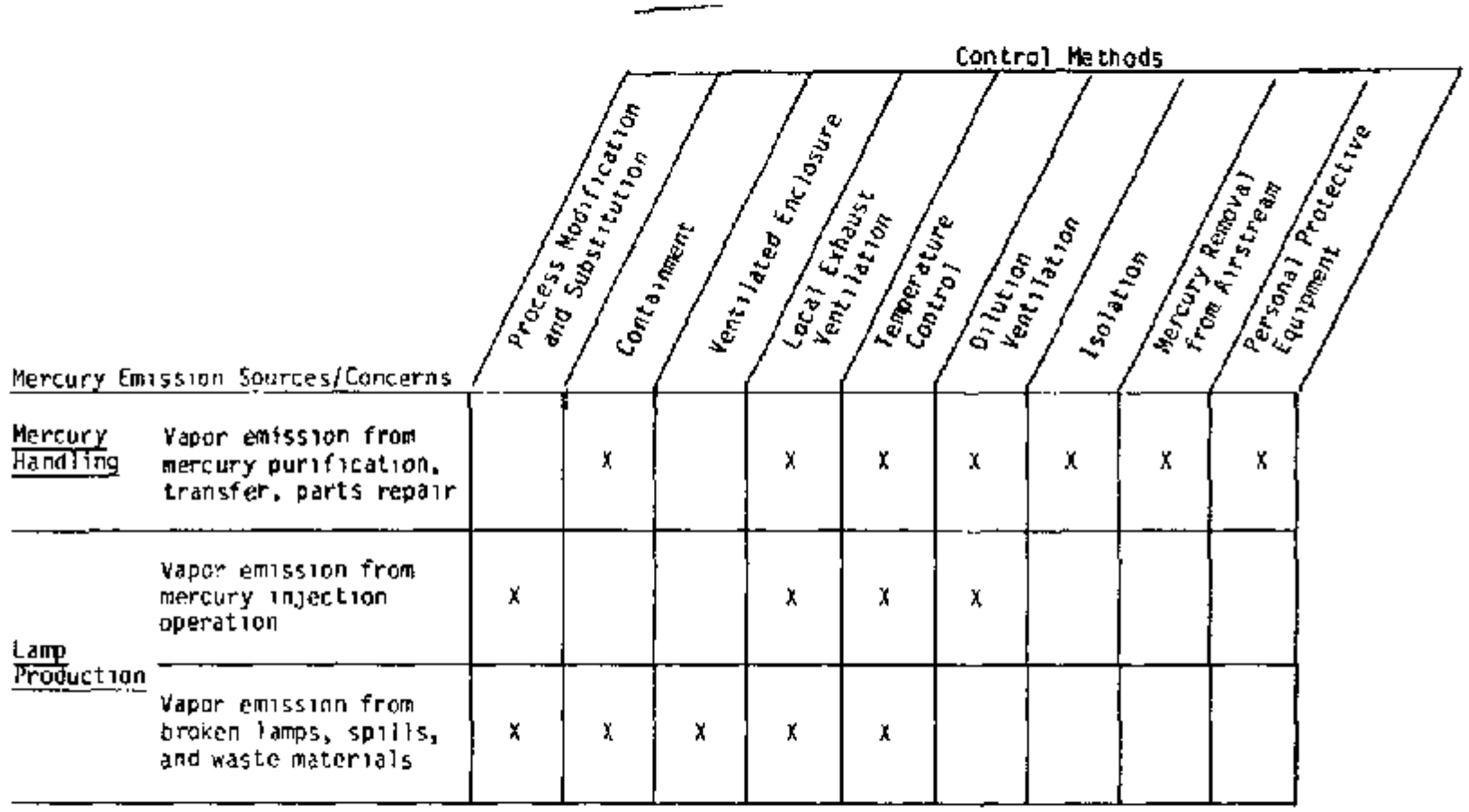

\section{DENTTSTRY}

Mercury is a component of the dental amalgam used to fill cavities in teeth. The amalgamation process is generally untform across the indugtry, although sone clfnics use preenclosed dental capsules to reduce worker contact.

Dental amalgam is prepared by mixing mercury with an alloy. The alloy is in powder or pellet form and is usually composed of approxtmately 60 percent silver, 25 percent $t i n$, and 15 percent $z$ nc and copper. The alloy and an equal amount (by welght) of mercury are put inside a two-plece plastic capsule along with a pestle. By malntaining a 1 to 1 ratio of alloy to mercury, an optimal amalgam is formed with minimal residual mercury.

Mercury is added to the capsule using a hand-held mercury dispenser. The dispenser delivers a drop, or "spill," of mercury when the delivery button is pressed. One or two Bpills are usually used for each amalgam mixing, depending on the size of the filling to be made.

When the alloy pellet, mercury, and pestle have been put inside the open plastic capsule, the capsule is capped and placed in an amalgamator (an agitation device used for mixing). The capsule is agitated in the amalgamator for approxtmately 15 seconds. It is removed from the machine, uncapped, and emptied 1nto a glass Dappen digh or stainless steel amalgam we11 in preparation for use. 
Many dental factlities use preenclosed dental capsules that contain a pestle and enough mercury and alloy to complete an average tooth filling. The use of these capsules, which are avallable in bulk quanticles, eliminates the handling of elemental mercury.

Sampling ResultB, Emission Sources, and Control Methods. Air sampling results from two dental clinics which use preenclosed capsules are presented in Table IV-5. Mean area mexcury samples ranged from 0.001 to $0.002 \mathrm{mg} / \mathrm{m}^{3}$, and mean personal samples ranged from 0.002 to $0.005 \mathrm{mg} / \mathrm{m}^{3}$. Typical emission sources and the methods used to control them are presented in Table IV 6 . Additional information is avallable from the American Dental Association, 211 East Chicago Avenue, Chicago, Ill1nois 6061l, regarding mercury control in dental offices.

TABLE IV-5

Workplace Mir Concentrations of Mercury 1 in Two Dental Clinics

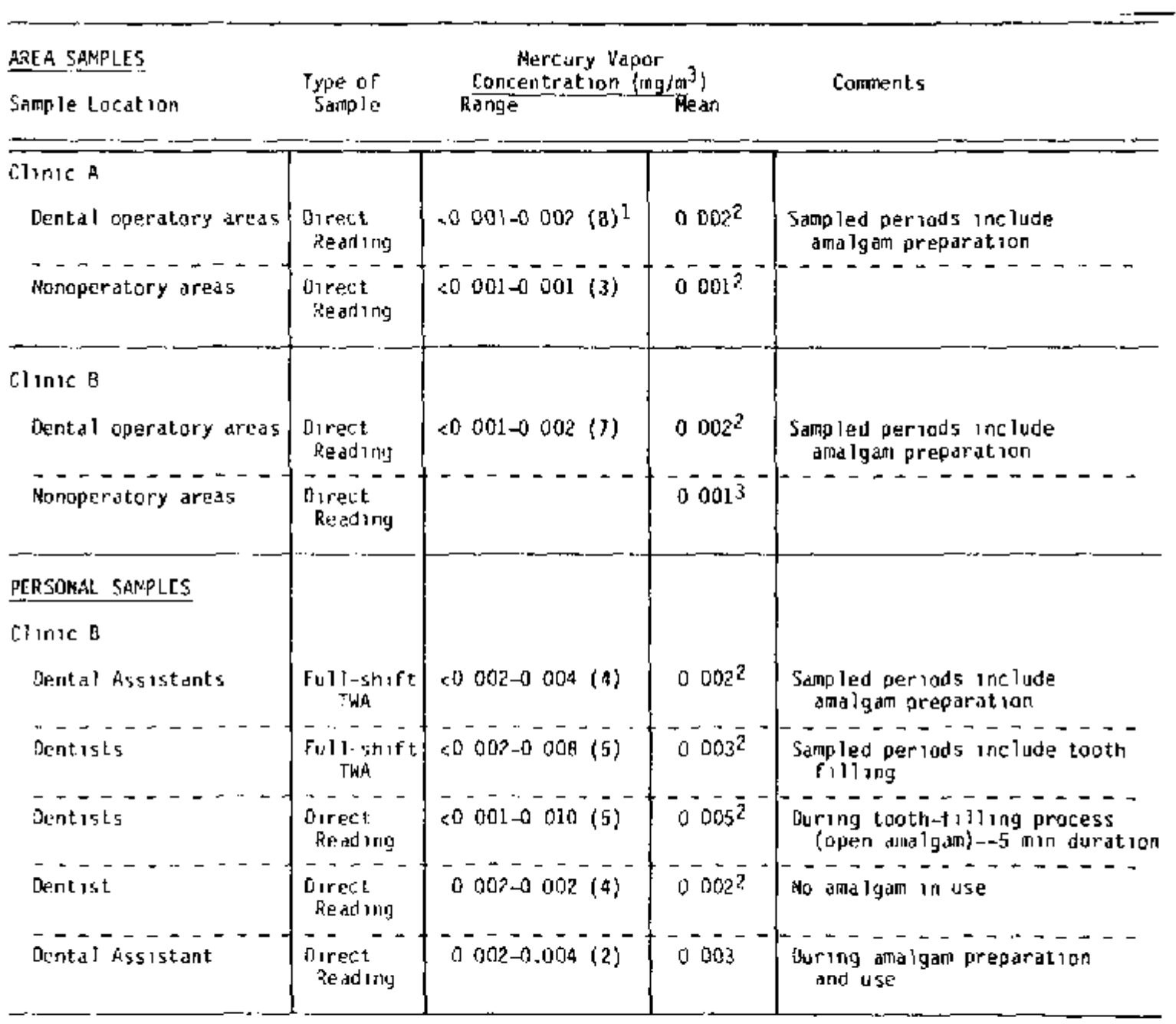

$\mathbf{l}_{\text {Nurners }}$ in parentheses inducate numbicr of simples taken

2Lower Timit of Jetection used in calculation of mean concentration

3one sample taken 
Mercury Enisston Sources and Control Methods for the Dental Industry

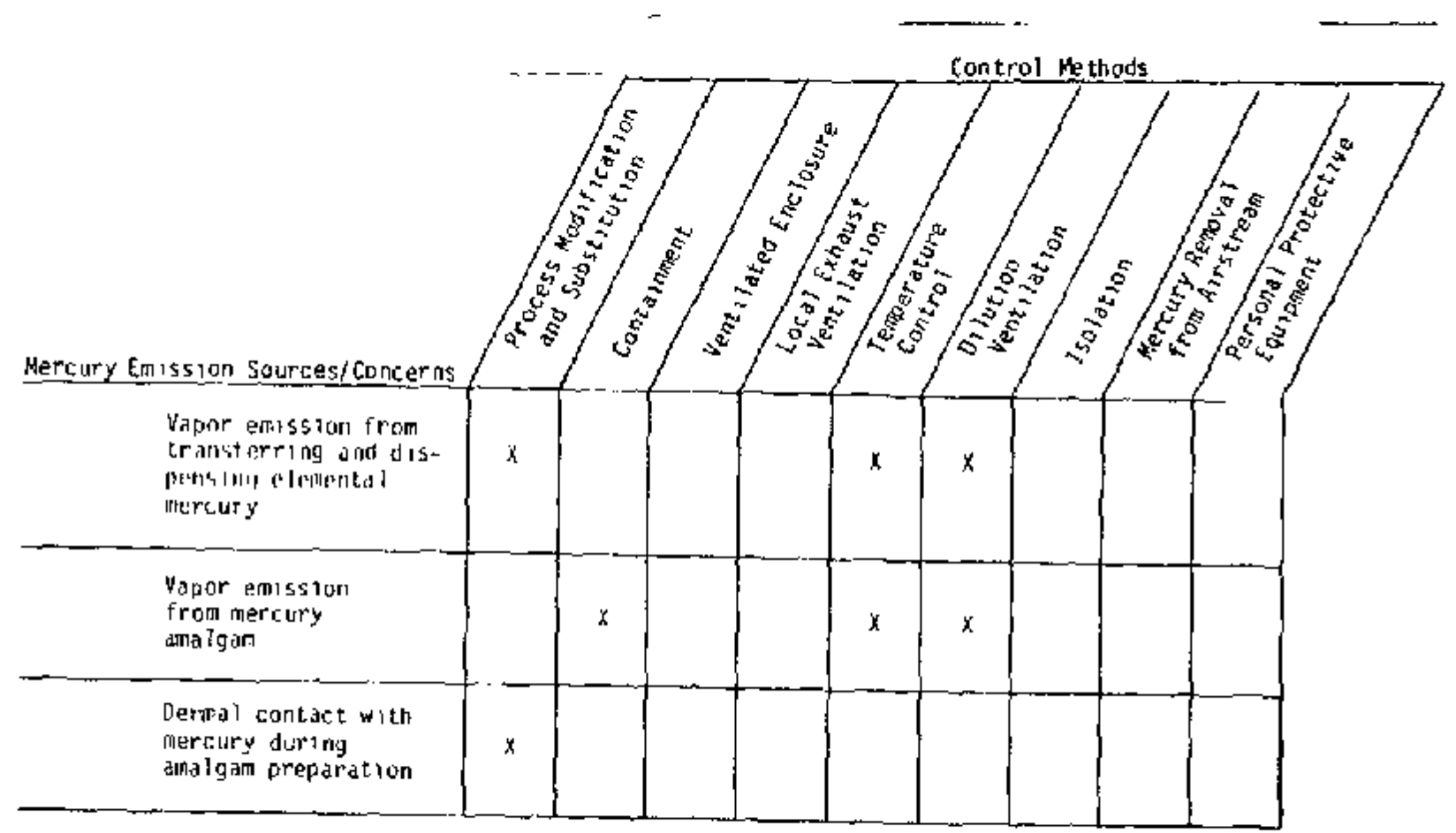

Mercury vapor concentracions in Clinfc A operating areas averaged approximately $0.002 \mathrm{mg} / \mathrm{m}^{3}$. Breathing zone concentrations did not increase $81 \mathrm{~g}^{-}$ nufleantly during analgam preparation or fllling. At Clinic B, increases in breathing zone concentrations, compared with background levels, were noted during some filling operations. The general workrom background concentration at thi clintc ranged from none detected $\left(0.001 \mathrm{mg} / \mathrm{m}^{3}\right)$ to $0.002 \mathrm{mg} / \mathrm{m}^{3}$.

Trme-weighted average personal sampling results at clinic $B$ ranged from none detected to $0,008 \mathrm{mg} / \mathrm{m}^{3}$; area sampling results ranged from none detected to $0.002 \mathrm{mg} / \mathrm{m}^{3}$. The employee with the highest reported exposure to mercury vapor did not use preenclosed amalgam capsules or any other mercury or mercury amalgan product on the day of sampling. The source (or sources) contributing to this employee's exposure was not determined.

\section{TEMPERATURE-SENSING INSTRUKENT MANUFACTURING}

The manufacture of mercury-containing temperature instruments varles according to the type of bulb or probe used in the instrunent. The mercury filling process also vartes slightly among different manufacturers. 


\section{Glass Thermometer Manufacturing}

The process of manufacturing glass thermometers begins with the cutting of glass tubes into specifled lengths. The bore size of each tube 18 determined volumetrically by measuring the length of a spectfled volume of mercury that 1s injected into random samples of tubes. Tubes are then grouped into batches of equal bore sizes,

Etther glass or metal bulba may be used to contain the mercury at the base of the glass tuhe. The procedure for attaching these bulbs are as follows:

a. Glass Bulbs

One end of the tube is heated over a burner and a short glass tube is foined to $3 \mathrm{t}$. This short tube is formed into a bulb by heating the open end, crimping it closed, breaking off the crimped plece of glass, and rounding off the remaining tip.

b. Metal Bulbs

Meta 1 bulbs have an attached caplllary extension approximately one-elghth inch in dlameter that is cut to a size determined by the bore size of each tube The caplliary extension is fused to one end of each glass tube. The sized tubes are grouped in batches and heated $1 \mathrm{n}$ an oven in preparation for mercury fllling.

Mercury filling is conducted th an isolated room. A typical mercury filling process is conducted inside a bell jar. Each batch of tubes is set with open ends down into a par. The pan 1s set under the bell jar, which is lowered and sealed. The tubes are heated to approximately $200 \mathrm{C}(400 \mathrm{~F})$ and a vacuum is drawn. Mercury is allowed to flow into the pan from etther an enclosed mercury addition system or a manually filled reservair. When the vacuut in the jar is released, a1r pressure forces the wexcury into the bulbs and capillaries. The pan of filled tubes is then manually removed from the bell jar, Excess mercury in the botton of the pan is refiltered and used again in the process.

Excess mercury in the tube stems is driven out the open ends by mmersing the bulb ends of the tubes in a hot water or oil bath (heating-out process). The mercury column is shortened to a speciflc height by flame heating the open ends (burning-off process). The tubes are cut to finished length just above the mercury colum and the ends of the tubes are sealed. A temperature scale is etched onto the tube, completing the assembly. All of these operations are done manually at varlous work stations.

\section{Thermal Sensing Element Manufacturing}

Some temperature-sensing instruments have a bulb and caplliary temperaturesensing device that uses the force of an expanding liquid (mercury) to operate external controls and indlcators (Figure IV-1). One such probe is manufactured as follows

Bulbs are made by cutting metal tubing to size and welding a plug to one end of the tube and a coupling plece to the other (open) end. A capillary is cut to a specifled length and heliarc welded to the coupleng at the open end of 


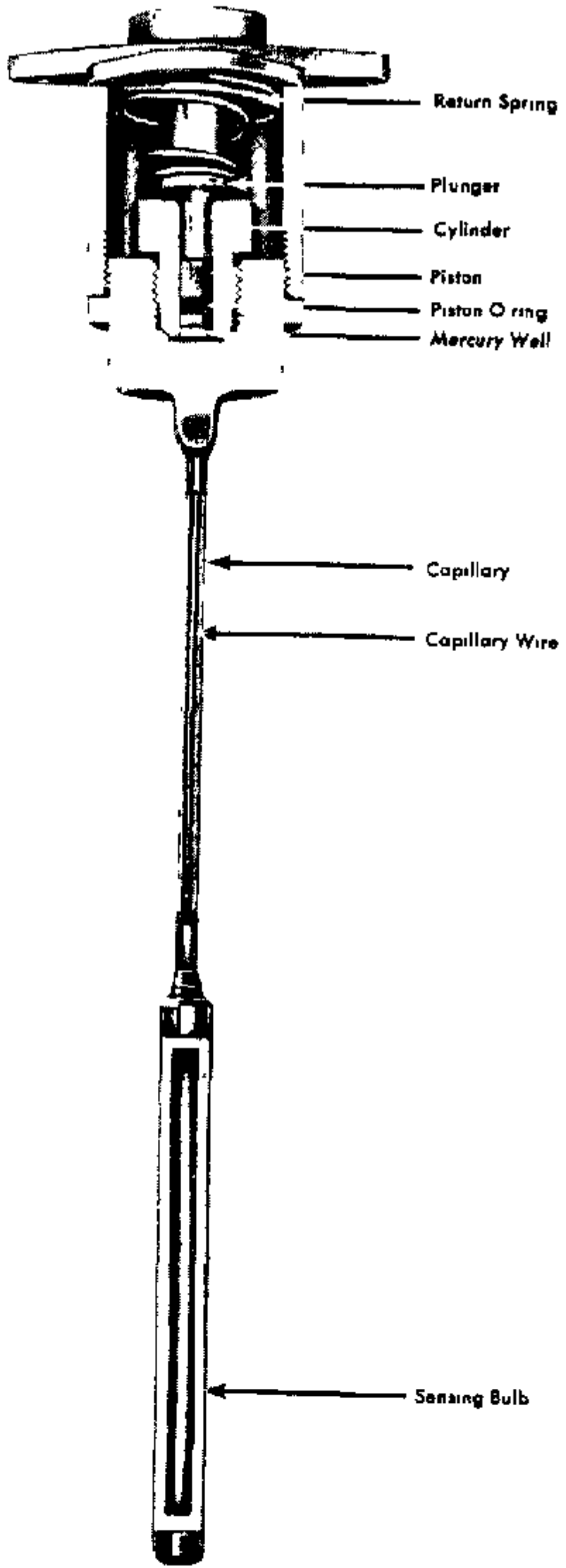

Figure IV-1. Temperature-Sensing Instrument. 
the bulb. The other end of the captllary is welded to a "head" that houses the mechanical section of the sensor. Completed assemblies are grouped in job lots based on captllary length.

Filling the bulb and capiliary assembly with mercury is performed in a vent1lated and enclosed tultistation mercury fllling machlne. Each station conststa of fittings attached to a central manifold through which the mercury is introduced to the captllary bulb assemblies A wire is inserted the length of the capillary so that the volume of mercury required to fill the capillary is reduced. This improves the performance of the sensing element because a greater mechanical movement in the head results from small volume changes in mercury.

The sensor assembly is transferred from the wire pusbing station to the final assembly station where a return spring and plunger are set into a temporary housing on the head of the sensor. The complete sensors with temporary housings are attached to controllers and/or indicating devices to complete the temperature instrument.

Sampling Results, Emission Sources, and Control Methods Alr sampling results frow two glass thermometer manufacturing plants surveyed are presented in Table IV-7. Typical emission sources and the methods used to control them are presented in Table IV-B.

During the surveys average worker exposures measured were below the OSHA PEL and the NIOSH recomended level at both of the manufacturers surveyed. The Fill Room of manufaccurer A had one fill unit that was used for one fill per day. Manufacturer $B$ had nine fill units that were used throughout the workday,

TABLE IV-7

Workplace AII Concentrations of Mercury in Two Thermometer Manufacturing Plants

\begin{tabular}{|c|c|c|c|c|}
\hline$\frac{\text { ARFA SAMPLES }}{\text { Samplo LOCAtian }}$ & $\begin{array}{l}\text { Type of } \\
\text { sample }\end{array}$ & $\begin{array}{l}\text { Mercury Vap } \\
\text { Concentration ?n } \\
\text { Ránge }\end{array}$ & $\frac{\left(m^{3}\right)^{3}}{m_{a n n}}$ & Conments \\
\hline 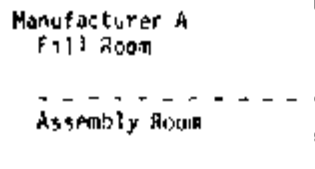 & $\begin{array}{l}\text { Ful linshift } \\
\text { TWA } \\
\text { Fuij-snift } \\
\text { TWA }\end{array}$ & $\left\{\begin{array}{l}0006-0023(5)^{1} \\
\times 0002-0005(2)\end{array}\right.$ & $\begin{array}{l}0035 \\
000--\end{array}$ & No open thamboters \\
\hline 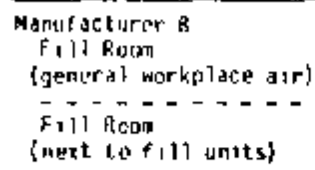 & $\begin{array}{l}\text { Full shift } \\
\text { TWA } \\
\text { Fuli-shift } \\
\text { TWR }\end{array}$ & $\left\{\begin{array}{l}0038-0054(3\} \\
0037-0 \text { tod }(3)\end{array}\right.$ & $\begin{array}{l}0040 \\
0.095\end{array}$ & $\ldots-\ldots+\ldots-\ldots$ \\
\hline \multicolumn{5}{|l|}{ PERSONAL SAIPLFS } \\
\hline $\begin{array}{l}\text { Manufacturer A } \\
\text { Fil Aocon Oderalors } \\
\text { Manufactorpr B } \\
\text { FI11 Room Operators }\end{array}$ & 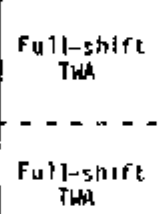 & $\begin{array}{l}0015-0015(2] \\
-\ldots--\ldots \\
0036-0061(3)\end{array}$ & $\begin{array}{c}0015 \\
---- \\
0049\end{array}$ & 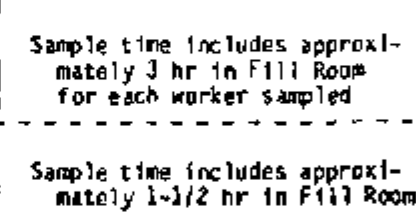 \\
\hline
\end{tabular}

$1_{\text {Numhers }}$ In parentheses Indicate number of samples taken 
Mercury Enission Sources and Control Methods for the Thermometer Manufacturing Industry

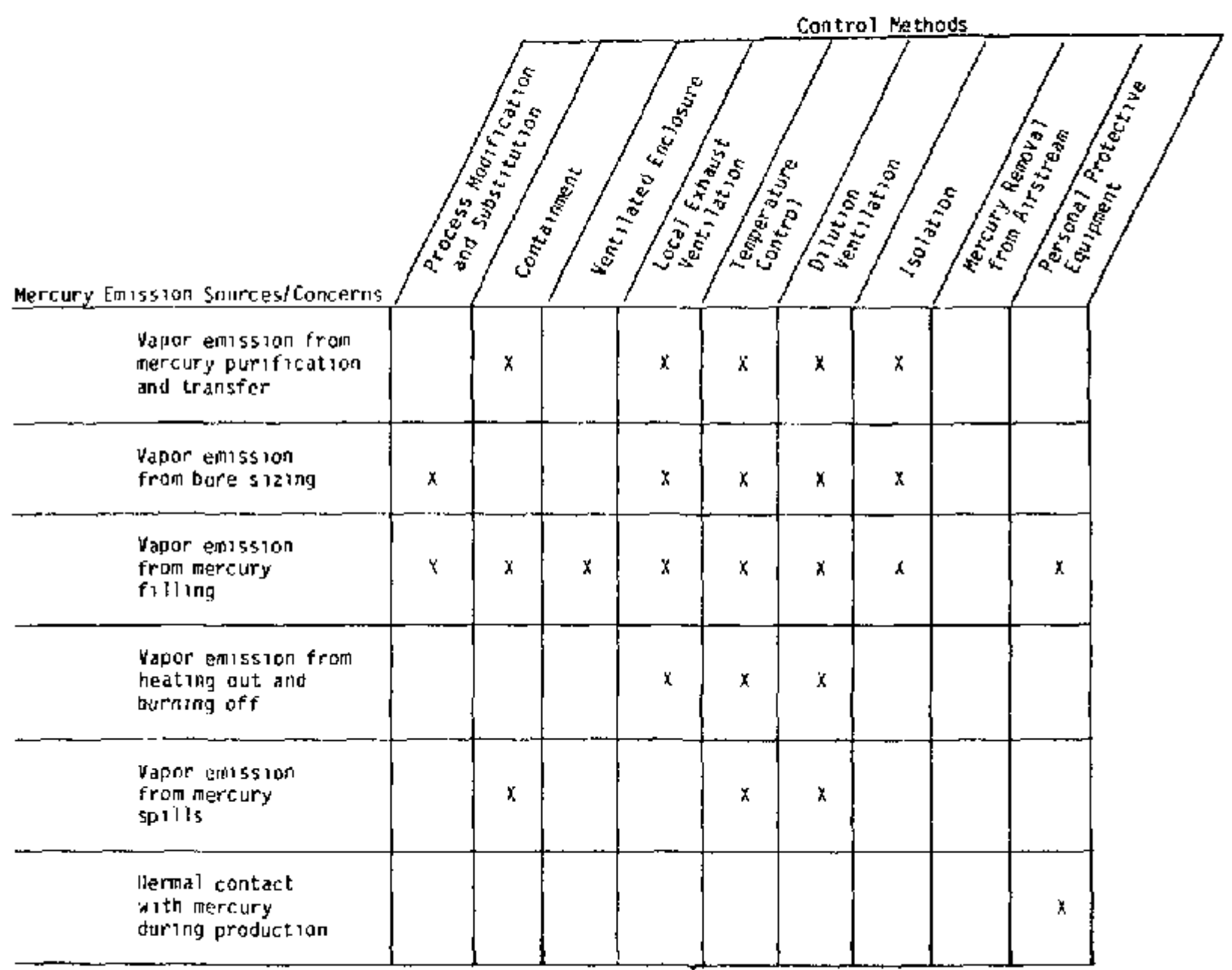

\section{E. ELECTRICAL SWITCH MANUFACTURING}

Mercury is used extensively in electrical switches for thermostats and for silent wall switches. The unique propertiea of the metal enable it to flow and make electrical confact upon actuation by an outside mechanical force or by gravity. Mercury switches for thermostats are small glass tubes containing mercury and metal electrodes (contacts). Mercury switches for wall switch application are button-shaped metal cans containing mercury, contacts, and an jnsulator. The manufacturing process descriptions for the two types of swatches are presented below:

\section{Mercury Switch for Thernostats}

Metal electrodes used for contacts are inserted into small glass tubes (0.350.61 inch in diameter) and sealed in place prior to mercury filling by using an operation called pressing and sealing. The electrodes are placed and 
positioned 1nside the tubes. One end af the tube 18 heated, constricted, crimped closed around the electrodes, and sealed. The tubes are then cleaned in preparation for mercury filling.

Mercury 1s injected into the open end of the glass tubes on a multistation rotary fill machline. Each station has a device for holding a glass tube and a mercury reservoir.

The fill sequence is as follows:

- Glass tubes are loaded on the wach1ne.

- Each tube is evacuated in preparation for fllling.

- Mercury is dispensed tnto the tube when it reaches the fill station.

- Vacuum is released and residual mercury in the platon shaft is drawn into the tube.

- The open end of the tube is heated, constricted, and sealed,

o Excuss glass is pulled away from the seal and discarded through $a$ discharge chute into a bucket of water.

- The completed fflled tube falls into a transport container.

Low-volume products are filled with mercury at a manual fill station by using the same f1ll sequence. Whre leads are then attached to the contacts of the electrodes and the switch is complete.

\section{Mercury Buttons for wa1l switches}

The mercury button containg a metal shell, metal ring, ceramic center, glass preform, center contact, and approximately $3 \mathrm{~g}$ of elemental mercury. The metal ring, glass preform, ceramic center, and center contact are assembled on a seraiautomatic loader, and the subassembly is fused together in a sealing furnace

The mercury fill operation as conducted on a rotating multistation welding machlne. Metal cans are gravity fed into carrier cups on the machine. The cups rotate through three progressive assembly stations: (1) the cans are filled with approximately $3 \mathrm{~g}$ of mercury, (2) the subassemblies are then manually placed in the can, and (3) the can is evacuated and weided closed. The butcons are cleaned, zinc plated, and used as a component for wall switch assemblies.

The mercury addition system is completely enclosed up to the point of 1 nsertion into the metal can. Mexcury is moved through tubes from an 800-pound storage container to a 3-gallon hold tank. Th1s is accomplished by pressurization with hellum to 15 pounds per square inch. Mercury is released from the hold tank and dropped through a metal tube into the metal can. Controlled releage is accomplished uaing a rotating slide gate synchronized to the speed of the welding machine. 
Sampling Results, Emtss lon Suurces, and Coulrol Nethods

Air sampling results from two electrical switch manufacturing plants surveyed are presented in Table IV -9 . Although the manufacturing processes used at each plant were different, the filling and sealing processes at both plants were conducted in an lsolated Fill Room. In each process, welding machines were used in close proximity ta mercury or parts contaminated with mercury, resulting in an increased potential for worker exposure to mercury vaportzed by the heat of the machines. Typlcal emission sources and the methods used to control them are presented in Table IV-10.

Alr sampling results from the two switch manufacturing plants show no mercury vapor alrbotne concentration above $0.060 \mathrm{mg} / \mathrm{m}^{3}$, and the mean values below the $0.050 \mathrm{mg} / \mathrm{m}^{3} \mathrm{NLOSH}$ recommended level during the surveys.

TABLE IV-9

Workplace Air Concentrations of Mercury in Two Electrlcal Switch Manufacturing Plants

\begin{tabular}{|c|c|c|c|c|}
\hline \multirow{2}{*}{$\begin{array}{l}\text { AREA SAMPLES } \\
\text { Sample Location }\end{array}$} & \multirow{2}{*}{$\begin{array}{l}\text { Type of } \\
\text { Sample }\end{array}$} & \multicolumn{2}{|c|}{$\begin{array}{c}\text { Mercury Vapor } \\
\text { Concentration }\left(\mathrm{mg}^{3} / \mathrm{m}^{3}\right)\end{array}$} & \multirow[t]{2}{*}{ Comments } \\
\hline & & Range & & \\
\hline $\begin{array}{l}\text { Manufacturer A } \\
\text { (various locations) } \\
\text { fill Room } \\
\text { Switch Handling Area }\end{array}$ & $\begin{array}{l}\text { Oirect } \\
\text { Reading } \\
----\cdots-- \\
\text { Oirect } \\
\text { Reading }\end{array}$ & 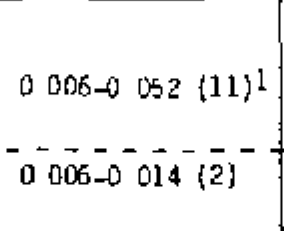 & $\begin{array}{c}0014 \\
-0 .--\end{array}$ & $\begin{array}{l}\text { Samples are taken at various } \\
\text { locations throughout Fil1 Racm } \\
\text { Switches are sealed }\end{array}$ \\
\hline $\begin{array}{l}\text { Manjlacturer B } \\
\text { (various locations) } \\
\text { fill Room } \\
\text { Fili Room } \\
\text { Subasscmbiy Area }\end{array}$ & $\begin{array}{c}\text { Direct } \\
\text { Reading } \\
\text { Fult-sh1ft } \\
\text { TWA } \\
---- \\
\text { Direct } \\
\text { Reading }\end{array}$ & $\begin{array}{l}0016-0040(6) \\
--\overline{0}-\overline{0}-\overline{-18} \\
005--\overline{(8)} \\
0006-0008(3)\end{array}$ & $\begin{array}{c}0.02 \mathrm{E} \\
+--\overline{-} \\
0010 \\
--0=\end{array}$ & $\begin{array}{l}\ldots+\ldots+\ldots+\ldots-\ldots \\
\text { Sinitches are sealed }\end{array}$ \\
\hline \multicolumn{5}{|l|}{ PERSONAL SAMPLES } \\
\hline $\begin{array}{l}\text { Manuf acturer } \mathrm{B} \\
\text { We lder Operator }\end{array}$ & $\begin{array}{c}\text { FuI } 1-\operatorname{sh} 1 f t \\
\text { TUA }\end{array}$ & $0046-0 \quad 048\{2\}$ & 0047 & $\begin{array}{l}\text { Workers spend approxinately } \\
\text { B hr/day in F1ll Roam. }\end{array}$ \\
\hline QC Operator & $\underset{\text { TWA }}{\text { Full-shift }}$ & $0020-0060(2)$ & 0035 & $\begin{array}{l}\text { harkers spend apgroximateiy } \\
\text { B hriday in Fill Room. }\end{array}$ \\
\hline
\end{tabular}

lNumbers in parentheses indicate number of 5 amples taker 
Mercury Emsston Sources and Control Methods for the Electr1ca1 Switch Industry

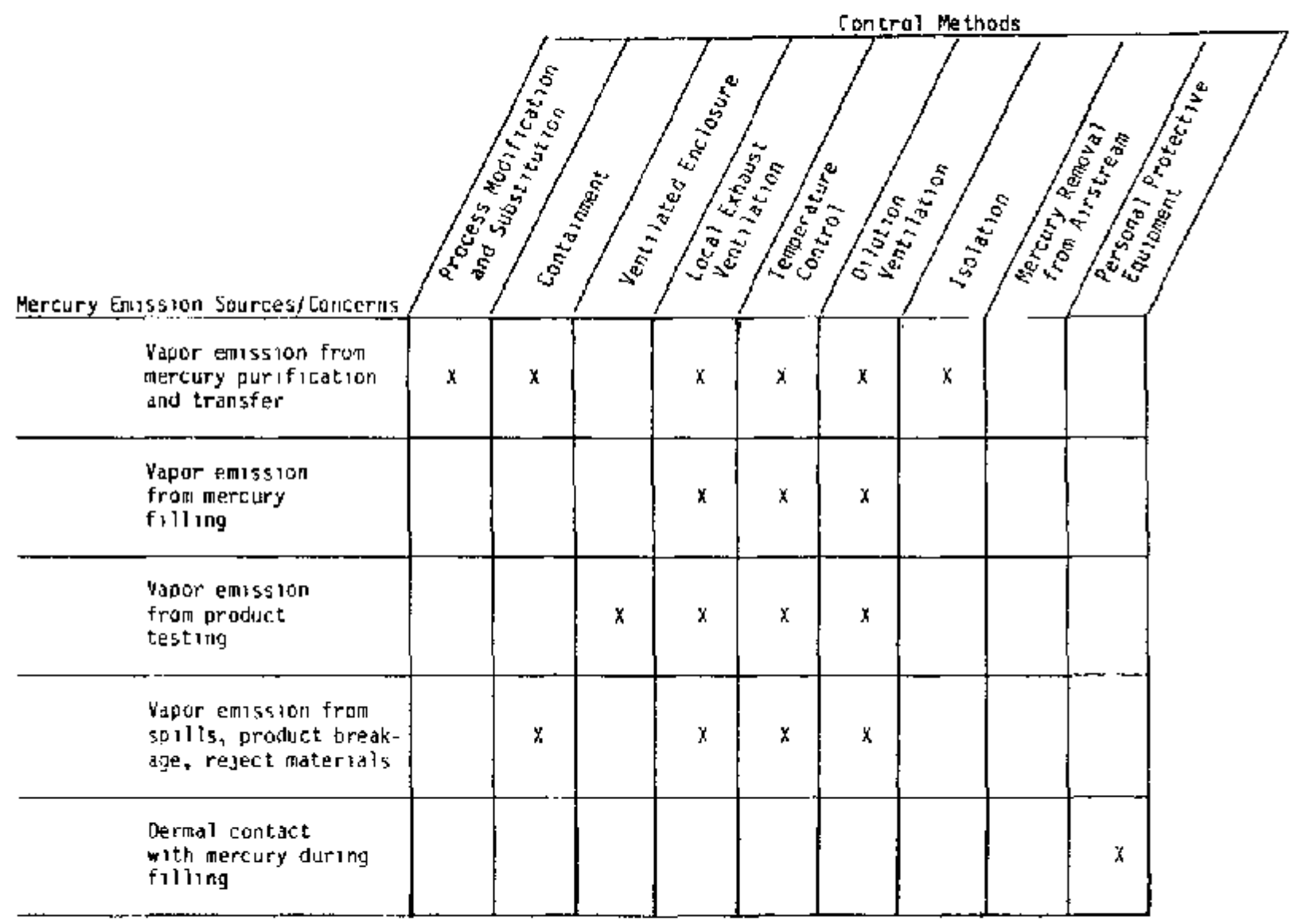

Mercury 1s used in electrical applications in several manufacturing processes. Most of these processes do not constitute a significant percentage of mercury consumption, Eince mercury is not a part of the final product. However, in the chlor-alka1, manufacturing process, large volumes of mercury are used in electrolytic cells. The process descriptions of a typical chlor-alkali operation and other mercury-using operations are presented below.

\section{Chlor $\rightarrow$ Alkali}

A concentrated brine solution is needed to produce chlorine and caustic in mercury cells. The solucton is made by pumping spent (weak) brine through a salt saturator. The saturated brine is chemlcally treated and clarified to remove Impurities. After clariftcation, the brine is pumped thraugh a series of filters to the electrolytic mercury cells for use in the process. 
The electralytic mercury cell is a steel channel bloped at an angle of approximately 7 degrees. A typical chlor-alkali cell is shown in Figure IV-2. It 15 covered wath a sheet of rubber, Teflon, or rubber-coated steel. Inside the steel channel are several sets of anodes that are attached under the cover by copper posts. Rubber seals are used to prevent leakaye around the pasts where they penetrate the cover. The depth of the anode in the metcury cell is controlled by adjusting the position of the copper posts. Anode depth must be adjusced constantly to optimize the electrolytic reaction taking place in thi cell. Ustally d computer system is used to actuate a positioner that adjusts the anode depth. At the lower end (outlet) of the mercury cell, there is an outlet box for removal of the brine solution, a decomposer (a cylindrical reaction vessel approximately 4-1/2 feet high and 3 feet in diameter) for the removal of hydrogen and caustic soda, and a mercury pump for returning the mercury to the high end (inlet) of the mercury cell.

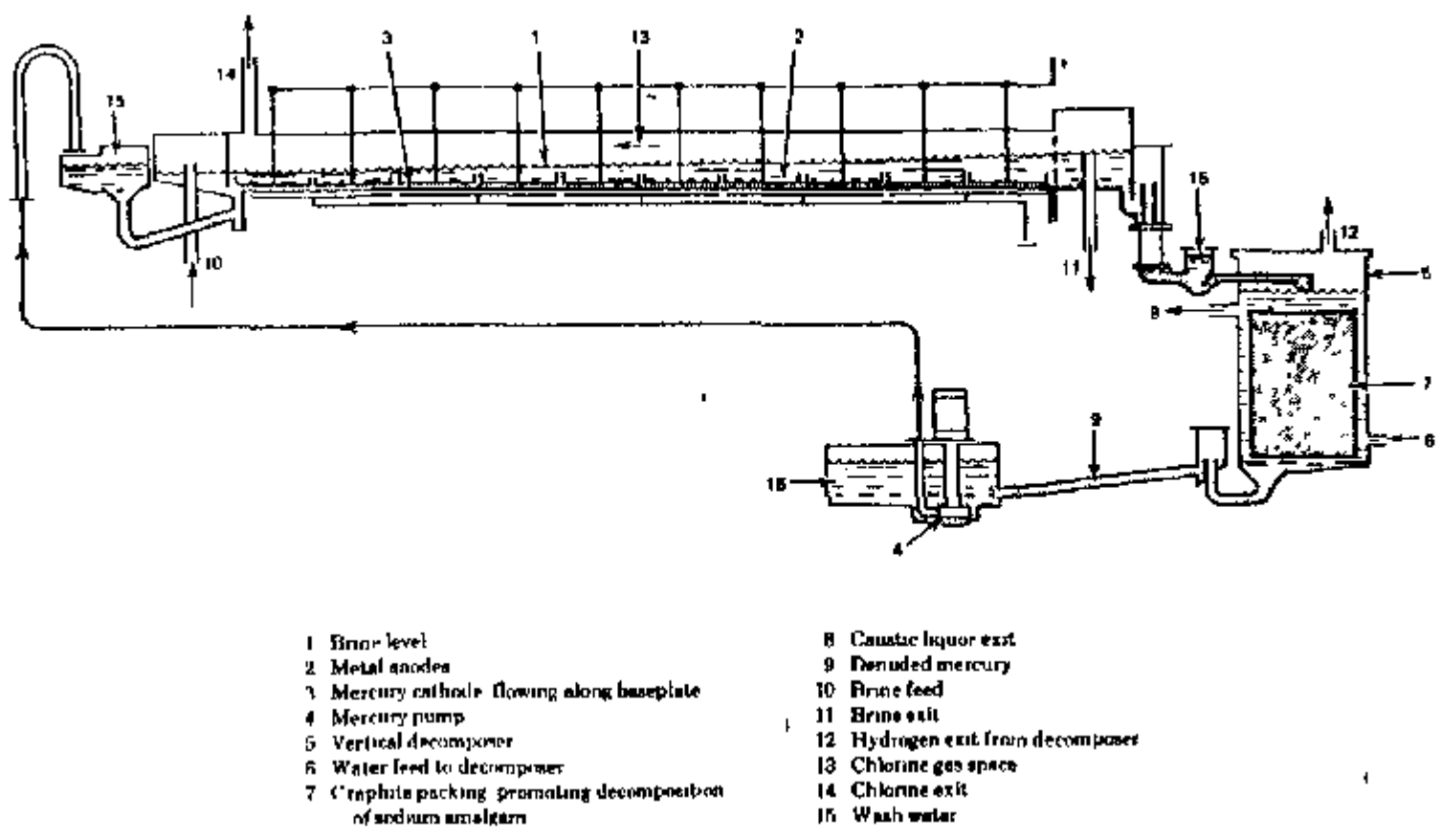

F1gure IV-2. Typledi Chlor-Alkal1 cell.

Mercury, which acts as the cathode, flows along the cell botton at a specifred depth below the anode. The brine solution is introduced to the inlet end of the cell and flows between the anode and the mercury cathode. Vo1tage is applied between the anode and the mercury cathode through large electrical bus bars. The current causes an electrolytic reaction in which the chlorine fons in the solution loge an electron and the sodium ions gain an electron. Chlorine gas bubbles out of the solution and flows out of the cell through a collection header located at the inlet of the cell. The sodium combines with the mercury to form an amalgam that flows down towards the outlet box at the outlet of the cell. The heavy sodlum amalgam flows 
below the weak brine. A submerged weir in the outlet box is designed so that only the amalgam can flow past it. Weak brine 15 decanted of $f$ the top of the stream through a drain pipe and 15 returned to the brine system. The amalgam passes through the outlet box 1nto the decomposer where it reacts wath water to form caustic soda dnd hydrogen gut. This is an exotherm1c chetncal reaction. The concentration of the caustic soda produced is controlled to approximately 50 percent by regulating the flow of water into the decomposer. The caustic level is mafntalned in the vessel.

The caustic produced is dratned from the decomposer, filtered, cooled, and stored. Hydrogen ledves the decomposer through the top and passes through a condenser to remove mercury vapor. After turther mercury removal using a molecular sleve, the hydragen is burned in the plant botlers. The chlorine gas from the cells is cooled, dried, Jiqueiled, and stored

The mercury, stripped of sodium in the decomposer, flows through a pipe at the bottom of the decomposer and into a mercury hold tank. A centrifuga $\downarrow$ pump is used to return the mercury to the inlet end of the cell for reuse in the electrolytic process

Sampling Results

Alr sampling results from a chIor-alksli production facility surveyed are presented in Table $[Y-1]$

TABLE IV-II

Workplace Air Concentrations of Mercury in a Chlor-Alkali Plant

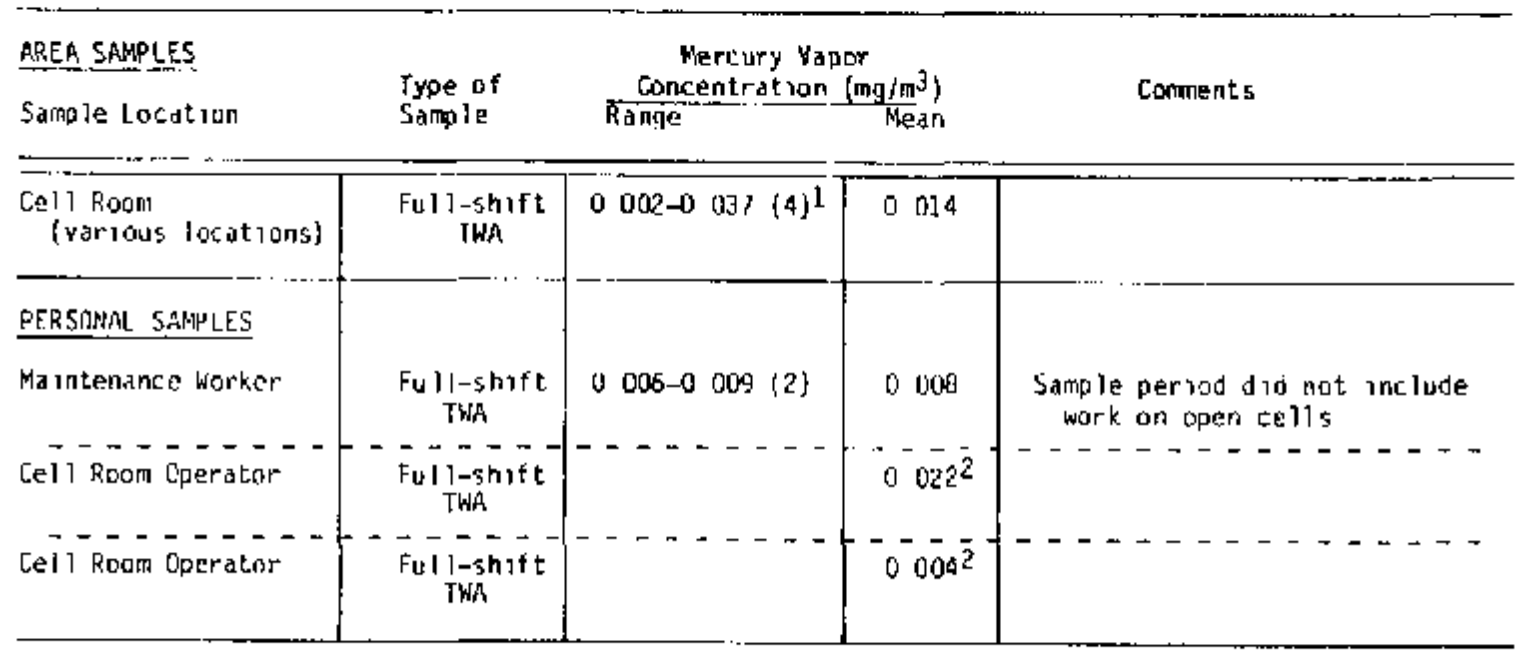

Jumbers in parentheses indicate number of samples taken

Zone sample. taken

Dally TWA concentrations in the workplace area ranged from 0.002 to 0.037 $\mathrm{mg} / \mathrm{m}^{3}$ with a mean of $0.014 \mathrm{mg} / \mathrm{m}^{3}$. These area sampling results taken during the survey were in general agreement with recent plant air sampling results. Mean personal exposure concentrations ranged from 0.004 to 0.022 $\mathrm{mg} / \mathrm{m}^{3}$. 
The persondl sampling results include all coutine activities for which a potential for exposure to mercury exists, fncluding taking samples of cell solutions, opentng cell inlet and outlet boxes, and contamination of cloth1ng items with mercury droplets which may volatilize.

Maintenance workers are occasionally exposed to mercury vapor at concentrations in excess of cell room background levels. These occasions include taintenance work on open cells dird cleaning cell bottoms. Respirators are required for both of these activitfes. Malntenance workers at this plant did not perform any activities assoclated with increased exposure to mercury during this survey.

\section{Tungsten Bar Sinterting}

Tungsten, in the form of dense bars, is used as a raw material for the manufacture of lncandescent lamp fllaments. The manufacturing process begins with the pressing of tungsten powder into long, thin bars of specified weights. The bars, strengthened and denslfied by presintering in a muffle furnace, are sintered wth a high-amperage electrical current. Mercury is used as a continuoug electrical contact in the sintering process. It is contained in pools, calied mercury cups, located inside each sintering unit. The sintering units (treating bottles) are located inside ventilated enclosures.

Aftex sintering, the bars are cooled to room temperature and the tungsten density is deternined Mercury is used for density measurements because of lts high specific gravtty. The bars are manually immersed in a poot of mercury and the weight of the displaced morcury is determined in order to calculate bar density. When the bar is removed from the mercury pool, the mercury is manually brushed off into a tray of water located in front of the pool.

\section{Copper Plating}

High-purity copper foil, used for laminate in printed circuit boards, is produced using an electrodeposition process that requires the use of mercury as an electrical contact.

The production process begins by dissolving scrap copper in sulfuric acid to form a copper sulfate solution. The solution is gravity fed to a series of plating drum units where copper ians are removed from solution as free copper by electrodeposition. Each plating drum unit consists of a concrete cell to contaln the copper sulfate solution, a lead anode, a rotating titanlum drum (cathode), and a winding roll. A current is passed through the solution by establishing a voltage potential between the lead anode (submerged in the solution) and the druil cathode (which rotates so that part of Its surface is submerged in the solution). As the drum rotates, the copper is deposited on the drum surface as a continuous foll sheet. 
The plated foil $1 \mathrm{~g}$ peeled of $f$ of the drum and $1 \mathrm{~s}$ wound on a variable-speed winding roll. When sufficient foll has been wound on a roll, the roll is removed from the plating drum unit. It is then specially treated, annealed, slit, wrapped, and prepared for shipping

The rotation of the cathode drum necessitates the use of a rotating electrical contact between the bus bars and the drum. The contact is established using elemental mercury as a continuous contact between the rotating copper shaft of the drum and the electrical connections. A pool of mercury, termed "mercury well," is situated at one end of the rotating drum shaft. At tached to the shaft is a serles of copper discs that maintaln constant contact with the mercury while rotating through the pool. Mercury in the wells tends to heat up because of the electrical current that passeg through 1 t.

Sampling Results

Alr sampling results from a copper plating plant surveyed are presented in Table IV-12. Persona1 samples gave a mean of $0.025 \mathrm{mg} / \mathrm{m}^{3}$. The mean for the area samples was $0015 \mathrm{mg} / \mathrm{m}^{3}$. These results agreed with historical plant data.

TABLE IV-I?

Workplace Atr Concentrations of Mercury in a Copper Plating Plant

\begin{tabular}{|c|c|c|c|c|}
\hline $\begin{array}{l}\text { AREA SAMPLES } \\
\text { 5alngle Locat ion }\end{array}$ & $\begin{array}{l}\text { Type of } \\
\text { Sample }\end{array}$ & \multicolumn{2}{|c|}{$\begin{array}{c}\text { Mercury vopor } \\
\left.\text { Concentration (mg/m }{ }^{3}\right)\end{array}$} & Comments \\
\hline Drum Room & $\begin{array}{c}\text { Fult-shift } \\
\text { TWA }\end{array}$ & $0005-0022(2)^{1}$ & 0013 & $\begin{array}{l}\text { Mercury wells used as } \\
\text { electrical contacts }\end{array}$ \\
\hline Treating Foom & $\begin{array}{c}\text { Full-shift } \\
\text { TWA }\end{array}$ & & $0018^{2}$ & $\begin{array}{l}\text { Rotary eiectrical contact } \\
\text { in use }\end{array}$ \\
\hline PERSONAL SMMPIES & & & & \\
\hline Orum Operators & $\begin{array}{c}\text { Full-shift } \\
\text { TWA }\end{array}$ & $0.024-0026(2)$ & 0025 & \\
\hline
\end{tabular}

INumbers un parentheses indicate number of samples taken

Zone sample taken

\section{Electrical Standard CaLfbration}

Mercury is used as a contact in the calibration of electrical standards. A typical standard is a cylindrical wire-wound resistor, approximately 6 Inches hi.gh and 2 inches in diameter (Figure IV-3) The standard has two U-shaped contact bars, each of which has one end attached to the top of the standard and the other end positioned out to the side. The outer ends of these bars 
are ueed to contact a box-shaped electrical ratio device. Electrical contact is made by placing the standard between two pronga attached to the alde of the ratio device so that the contact bars on the standard rest inside recessed holes on the prongs. These recessed holes contain mercury (approximately $1 \mathrm{ml}$ ) to provide a low-resistance contact film between the bars and the prongs. Anather set of prongs is mounted on the opposite side of the electrical ratio device. This set is used to make contact with a known standard (similar to the other standard). The instrument is used to determine the ratio of resistance of the atandard being calibrated to the known atandard by adjusting a set of percentage dlals until the effective resistances are equal. The dial readings at this polnt show the ratio between the two standards. The actual reatstance of the standard being calibrated is determined by multiplying the ratio by the actual resistance of the known standard.

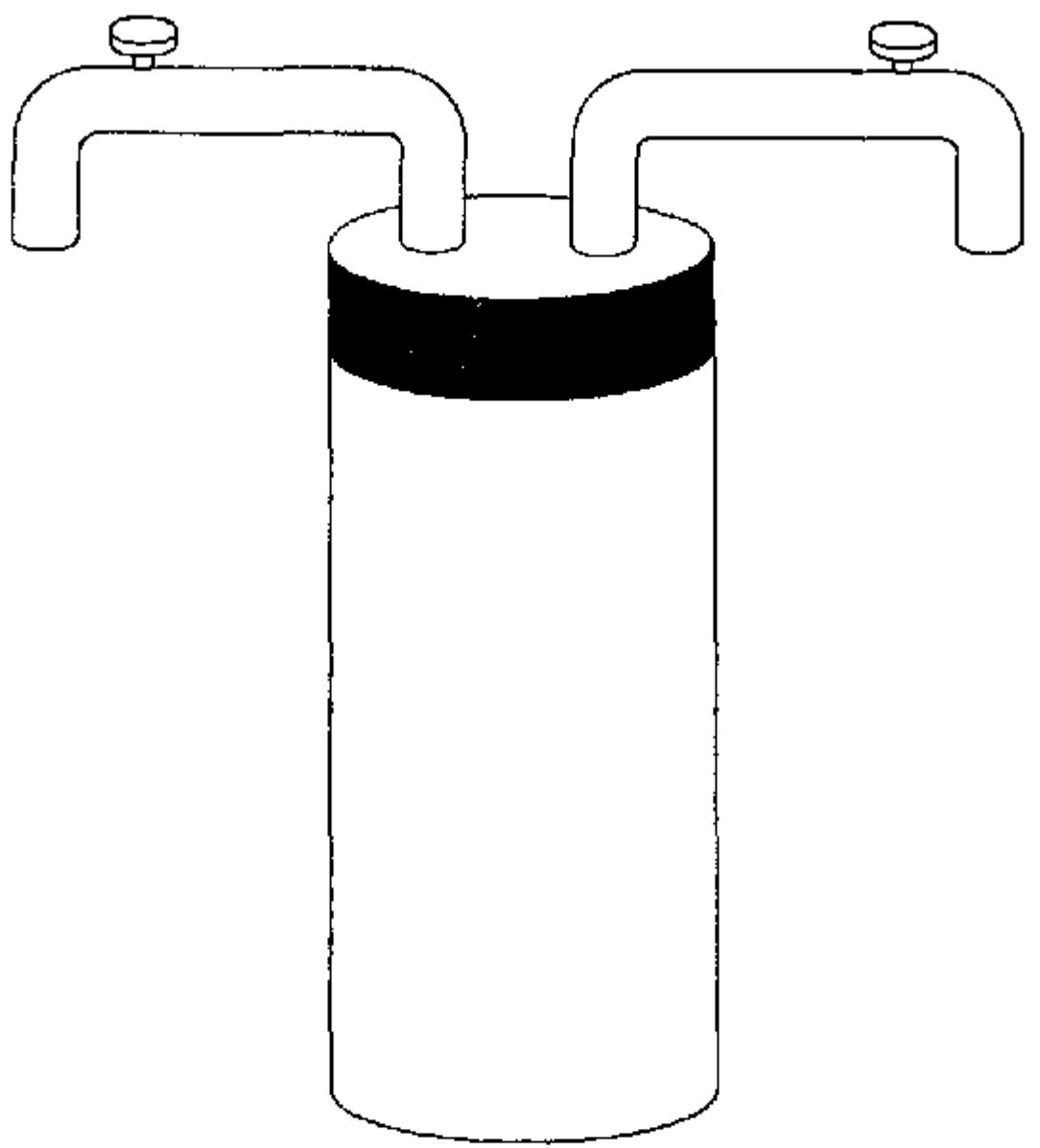

Figure IV-3. Typlcal Electrical Standard, 
recessed holes on the prongs. These recessed holes conta1n mercury (approximately $1 \mathrm{ml}$ ) to provide a low-resistance contact fllm between the bars and the prongs. Another sel of prongs is mounted on the opposite side of the electrical rat1o device. This set is used to make contact with a known standard (simlar to the other standard). The instrument is used to determine the ratio of resistance of the standard being calibrated to the known standard by adjusting a set of percentage dials until the effective resistances are equal. The dial readings at this point show the ratio between the two standards. The dctual resistance of the standard being calibrated is determined by multiplyting the ratto by the actual resistance of the known standard

The standardization process may also be conducted in a controlled temperature oll bath for greater accuracy. The ofl bath method of calibration involves the same proceduce described above except that the electrical ratio device has a different configuration and the contacts and mercury pools are immersed in an ofl bath.

Alr sampling was not conducted at thls facility during the site visit. However, most of the historical plant air sampling data that was reviewed showed mercury vapor concentrations below the PEL.

Typical emission sources in electrical processes using mercury and the methods used to control them are presented in Table rV-13.

TABLE IV-13

Mercury Emission Sources and Control Methods for Electrical Processes

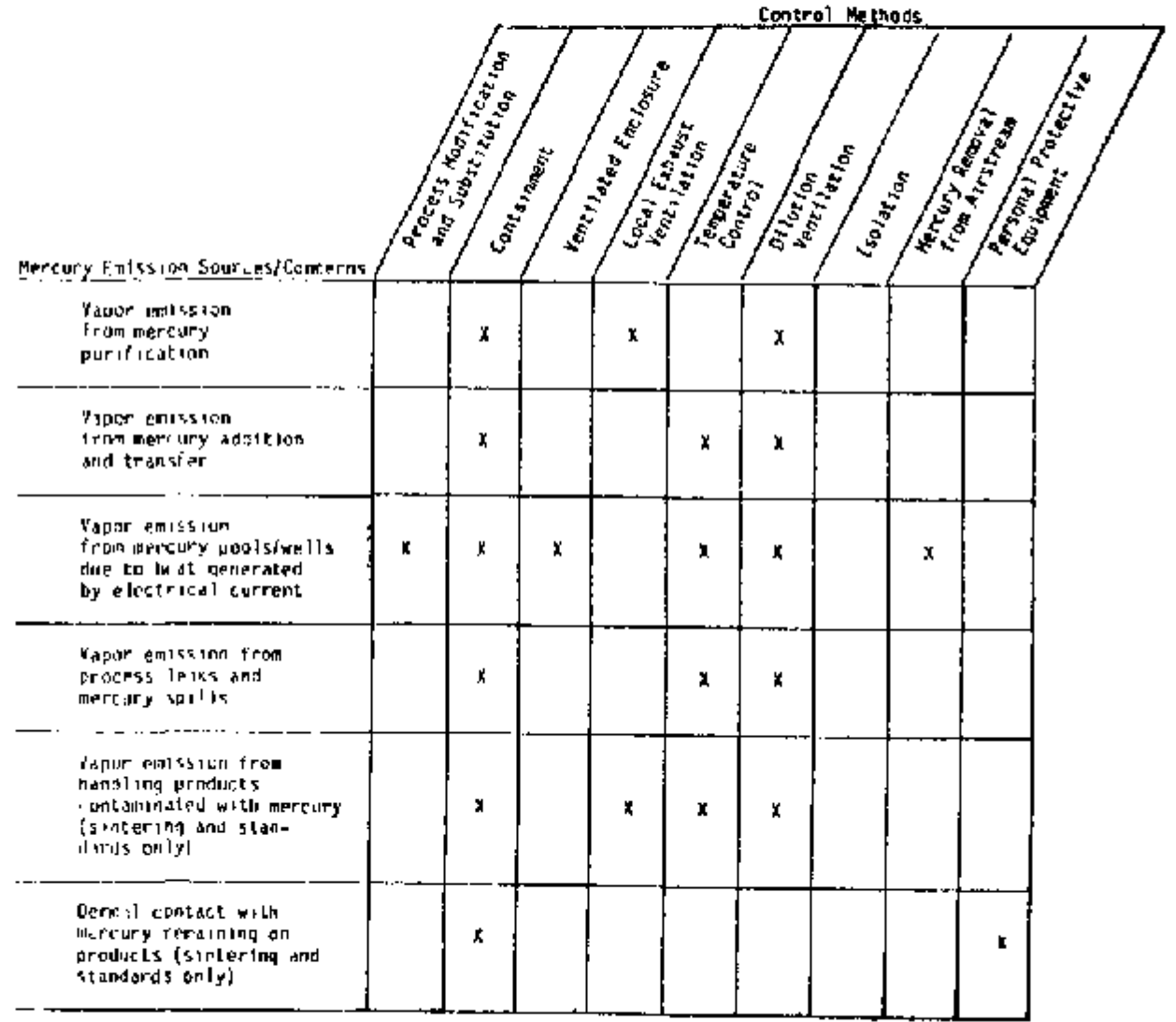




\section{G. MERCURY CHEMICAL PROCESSING/MANUFACTURING}

Production of purifled elemental mercury and mercury compounds involves distiling mercury and handling purticulate mercury compounds. Descriptions of these puriffcation and manufacturing proceases follow.

\section{Mercury Ore (Cinnabar) Processing}

Meccury-contafnung clay ore is ground in a grinding mill into particles that are fine enough to pertit separation and concentration of the mercury-containfing minerals by filotation. The particles pass through d cyclone separator that returns oversized particles to the grinder, while the remaining particles are slurried into a series of flotation cells. Agitation of the slurry, after the addition of methyl isobutyl carbinal as a frothing agent. and Cyanam 1 d A-242 as a collector, causes the mercury-contanning minerals to float and concentrate. The concentrate flows over the sides of the flotation units into launders that lead to d thickening tank. The concentrate is dewatered to 60 percent solids 1 n the thickener and pumped to a concentrate starage tank. Thickened concentrate is slurried and pumped through a twodisc, multileaf filter where $1 t$ is dewatered to 85 percent solids. It is then gravity fed to an enclosed bcrew conveyor that feeds the top of a multihearth furnace. $\mathrm{CaO}$ and $\mathrm{Na}_{2} \mathrm{~S}$ are added to chemically reduce the mercury contauntug minerals

The furnace discharge conststs of dust, mercury vapor, water vapor, sulfur dioxide, chlorine compounds, and other products of combustion. Mercury, condensed from the gas btream in a serles of 12 condensing tubes, $1 \mathrm{~s}$ collected in fiberglass-lined launders. The mercury then flows through a cleaning bath and is pumped to bulk storage tanks. It is double filtered and bottled in 76 -pound metal flasks or metal, metric-ton containers.

The underflow (waste slurry or "tallings") from the flotation process flows to a series of four settling ponds located adjacent to the plant site. The tallings are dewatered first by decantation and then by solar evaporation in the pands.

Simpling Results

Axr sampling results from a cinnabar processing factlity are presented in Table IV-14. As this table shows, the personal samples were an order of magnitude higher than the drea samples $\left(0.23 \mathrm{mg} / \mathrm{m}^{3}\right.$ compared to 0.024 $\left.\mathrm{mg} / \mathrm{m}^{3}\right)$. The personal samples were stmilar to plant sampling data. The area samples were one-half to one-fourth of typical plant data. The discrepancy between area and personal samples indfcates that behavioral components (such as work practlces or mercury contamination of work clothing) thay be an important factor in the total exposure. Prudent practice would indfate the need for additional sampling to 1dentify these factors, and appropriate measures to mitigate them. 
TABLE IV-14

Workplace A1r Concentrations of Mercury 2 a Cinnabar Processing Plant

\begin{tabular}{|c|c|c|c|c|}
\hline$\frac{\text { AREA SAHPLES }}{\text { Sample Locistion }}$ & $\begin{array}{l}\text { Type of } \\
\text { Sample }\end{array}$ & \multicolumn{2}{|c|}{$\begin{array}{l}\text { Mercury Vapur } \\
\text { Concentration }\left(\mathrm{mg}^{3} / \mathrm{m}^{3}\right)\end{array}$} & Corments \\
\hline $\begin{array}{l}\text { Flotation/Concentration } \\
\text { Area } \\
\text { Furnace Area }\end{array}$ & 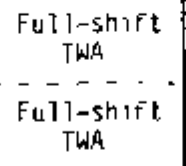 & $\begin{array}{l}000 /-0040(3)^{1} \\
0023-0036(9)\end{array}$ & $\begin{array}{c}0020 \\
--\overline{0 ? 8}\end{array}$ & $----\ldots-----\cdots$ \\
\hline \multicolumn{5}{|l|}{ PERSONAL SAMPLES } \\
\hline $\begin{array}{l}\text { Furnace Operator } \\
\text { Concenlratar Dperator }\end{array}$ & $\begin{array}{l}\text { Full-shaft } \\
\text { This } \\
\text { Full-shift } \\
\text { TWA }\end{array}$ & - & $\begin{array}{r}0260^{2} \\
---200\end{array}$ & $\begin{array}{l}\text { Full-time use of respirators } \\
\text { is required } \\
\text { Fuli-time use of respirators } \\
\text { is required }\end{array}$ \\
\hline
\end{tabular}

$l_{\text {flumbers }}$ in parentheses indrate number of samples taken

2ane sample token

\section{Mercury Retorting, Distilling, and Packaging}

Waste materials containing mercury are frequently processed in retorts to reclain the mercury Reject materials (e.g., defective batteries, broken glass tubes containing mercury, reject mercury compounds, mexcury sludges, etc.) are loaded onto metal trays and put into a furnace. When heated, the mercury vaporizes and rises into a condenser. The mercury that condenses into a collection chamber is usually impure and must be further distilled.

Distiliation is conducted in an insulated distillation vessed (still). Mercury is heated in the still until it vaporizes and rises into a condenser. Condensed mercury falls into a receiver vessel from which the mercury is drained into containers.

Sma1l-quantity bottlers of dastilled mercury use special filling devices with a volumetrac glass flask to control the amount of mercury put into each bottle. The mercury is poured into a hold tank above the filling device. The volumetric flask is connected to the hald cank by tubing. Mercury flows from the hold tank into the flask until. the flask overflows through a tube into an overflow bottle. Mercury is dispensed from the flask to a bottle by opening a valve at the bottom of the flask. Each bottle is capped immediately after filling. The mercury is usually bottled in 1 - or 5 -pound quantities. 
Sampling Results

Air sampilng results from a mercury processing factlity are presented in Table IV-15.

As this table shows, the facility exhiblted ambient mercury vapor concentrations of $0.15 \mathrm{mg} / \mathrm{m}^{3}$ in the fill room and $0.08 \mathrm{mg} / \mathrm{m}^{3}$ in the adjacent room at the anset of the survey. An appraisal of control strategles $1 n 1 \mathrm{t} i a l l y$ showed minor deficiencies in housekeeping practices. Further investigation showed that the central ventilation system for the facility had been operating with 100 percent recycled air, which could result in a bulldup of mercury vapors in the recycled atr. This was not in accord with the specifted operating procedures for the system, which required a 50 percent fresh air makeup. By adjusting air Intake louvers during the NIOSH visit, the proper operating condtion was achieved. The mean mercury concentration inthe fill room at these new conditions was 0.06 $\mathrm{mg} / \mathrm{m}^{3}$, and $1 \mathrm{n}$ the adjacent room $0.02 \mathrm{mg} / \mathrm{m}^{3}$. This experlence emphasizes the need for momicoring and alarm devices to measure and indicate proper performance of recirculation systems for exhaust air, since 100 percent recycle 1s, in any event, poor practice.

TABLE IV-15

Workplace Air Concentrations of Mercury in a Mercury Processing Plant

\begin{tabular}{|c|c|c|c|c|}
\hline$\frac{\text { AREA SAMPLES }}{\text { Sample Lacation }}$ & $\begin{array}{l}\text { Type of } \\
\text { Sample }\end{array}$ & $\begin{array}{l}\text { Mercury Va } \\
\text { Concentration } \\
\text { Range }\end{array}$ & $\frac{\left.n g / \pi^{3}\right)}{\operatorname{Me} a n}$ & Comments \\
\hline F11 ROOH & Direct Reading & $008-025(21)^{1}$ & 015 & 100 percent recycled aur \\
\hline Adjacent Roon & Direct. Redong & $005-011\{5\}$ & 008 & 100 pertent recycled a ir \\
\hline $\begin{array}{l}\text { Fill Room } \\
\text { (with makew alr) }\end{array}$ & Durect Rending & $0 \quad 04-0 \quad 08\langle 4\rangle$ & 006 & $\begin{array}{l}\text { Approxifnately } 50 \text { percent } \\
\text { fresh alr makeup }\end{array}$ \\
\hline $\begin{array}{l}\text { Adjzcent laoml } \\
(\text { w } 1 \text { th mikeup atr })\end{array}$ & Direct Reading & 0 al $-0 \quad 03\langle 3\rangle$ & 002 & $\begin{array}{l}\text { Approxmate } 1 \text { y } 50 \text { percent } \\
\text { fresh air makeup }\end{array}$ \\
\hline
\end{tabular}

$l_{\text {ivumbers }}$ n parentheses indrate number of samples taken

\section{Mercury Compound Manufacturing}

a. Mercuric Chloride

Mercuric chloride is produced by direct reaction of mercury with chlorine. Liquid mercury is pumped into a furnace and burned with chlorine gas. The combustion product is directed to a seting chamber where the dry mercuric chloride settles to the bottom. When the reaction and setcling are complete, the dry product is raked out and packaged in drums. 
b. Mercuric oxide

Mercuric oxide prectpitate may be produced using two different processes. In one process, liquid mercury is reacted with chlortne and brine to form mercuric chloride which is reacted with a caustic solution to form the mercurzc oxide precipitate

In the second process, mercuric nitrate 1s formed by dissolving lfquid mercury in nitric acid The mercurfe nitrate is neutralized with caustc to produce the mercuric oxide precipitate.

Mercuric oxide precipitate from elther process is washed, filtered, dried in ovens or in vacuum dryers, grourd, sized, and packaged.

c. Phenylmercurac Acetate

Phenylmercuric acetate is usually produced by refluxing benzene and acetic acid wath mercuric oxide at approx1mately $80 \mathrm{C}(176 \mathrm{~F})$. It is also produced by reacting mercuric acetate with benzene in a solution of acetic acid. The reactions take place tn large (approximately 2,000-gallon-capacity), glasslined reactors. PMA precipitate is filtered, dried in either a vacuun or a spray dryer, ground, and packaged. Liquid PMA is manufactured by mixing the PMA precipitate with low-molecular-wefght glycol and adjusting the pH to 8 with ammonia.

Sampling Results, Emission Sources, and Control Methods The results of anr sampling at a mercury compound manufacturer are presented in Table 18-16. Typical emission sources and the methods used to control them are presented in Table IV-17.

As Table ry-17 shows personal samplea for thr Reactor/Drummer Operator were $0.190 \mathrm{mg} / \mathrm{m}^{3}$. The high area sampling result ( up to $0.525 \mathrm{mg} / \mathrm{m}^{3}$ near the floor, as andicated by direct reading instruments $)$ indicate that general housekeeping may be a major contributor to this exposure. Housekeeplng procedures used for handling mercury compounds are described in the sections on Behavioral Controls, p. 96. 
TABLE 1V-16

Workplace AIr Concentrations of Mercury in a Phenylmercurle Acetate Manufacturing plant

\begin{tabular}{|c|c|c|c|c|c|c|}
\hline $\begin{array}{l}\text { AREA SAMPLES } \\
\text { 5amole tacation }\end{array}$ & $\begin{array}{l}\text { Type of } \\
\text { Salupte }\end{array}$ & $\begin{array}{l}\text { Mercury Vapor } \\
\text { Concentration (mg/min) } \\
\text { Ranige }\end{array}$ & $\begin{array}{l}\text { Type of } \\
\text { Sample }\end{array}$ & $\begin{array}{l}\text { Particulate M } \\
\text { Concentration } \\
\text { (as total me } \\
\text { Range }\end{array}$ & $\begin{array}{l}\text { reury } \\
\text { mgdm } \\
\frac{\operatorname{cury}{ }^{3}}{\text { Medn }}\end{array}$ & Comanents \\
\hline $\begin{array}{l}\text { Reactor Rocni } \\
\text { General Workrooun } \\
\text { Air } \\
\text { Near Reactors } \\
\text { Near Reactors } \\
\text { Near Floor } \\
\text { Bending Room } \\
\text { Spray Drying } \\
\text { Ronm }\end{array}$ & 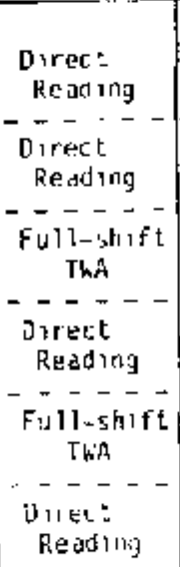 & 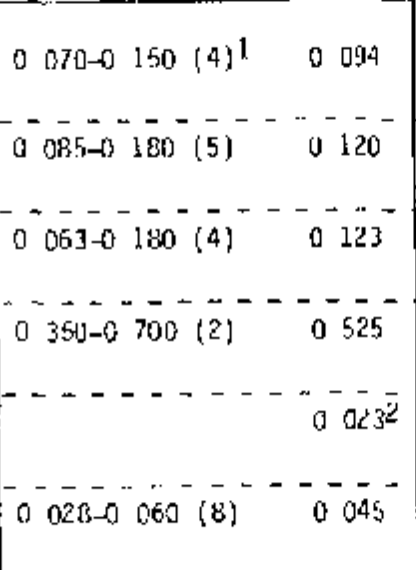 & 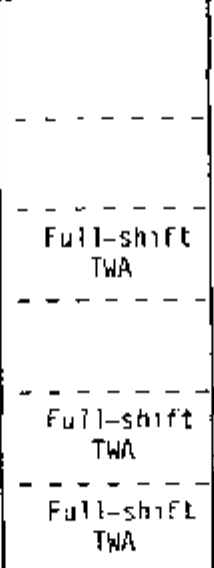 & 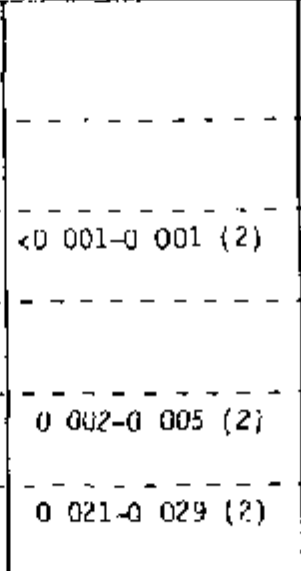 & $\begin{array}{c}---- \\
---- \\
0001 \\
---- \\
---- \\
0003 \\
-\ldots 025\end{array}$ & $\begin{array}{l}\text { PMC filtering and drumining } \\
\text { PML filtering and druntining } \\
\text { Pin bagging } \\
\text { Product (contasining PMA) } \\
\text { drying }\end{array}$ \\
\hline $\begin{array}{l}\text { PEKSONAL SAMPLES } \\
\text { Re actor/Drumer } \\
\text { Operator } \\
\text { Spray Dryer } \\
\text { Operator }\end{array}$ & 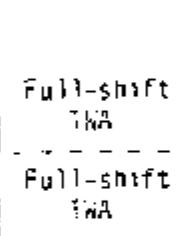 & 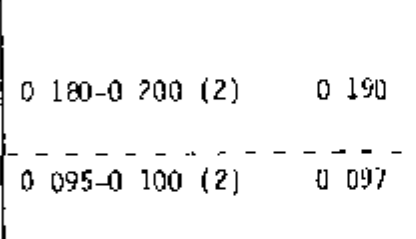 & & - & -- & $\begin{array}{l}\text { Conducting drumring } \\
\text { operations } \\
-----\ldots---\end{array}$ \\
\hline
\end{tabular}

\footnotetext{
loumers in parentheses indicate nimber of samples taken
} 20ne samole taken 
TABLE IV -17

Mercury Emission Sources and Control Methads for Mercury Chemical Production

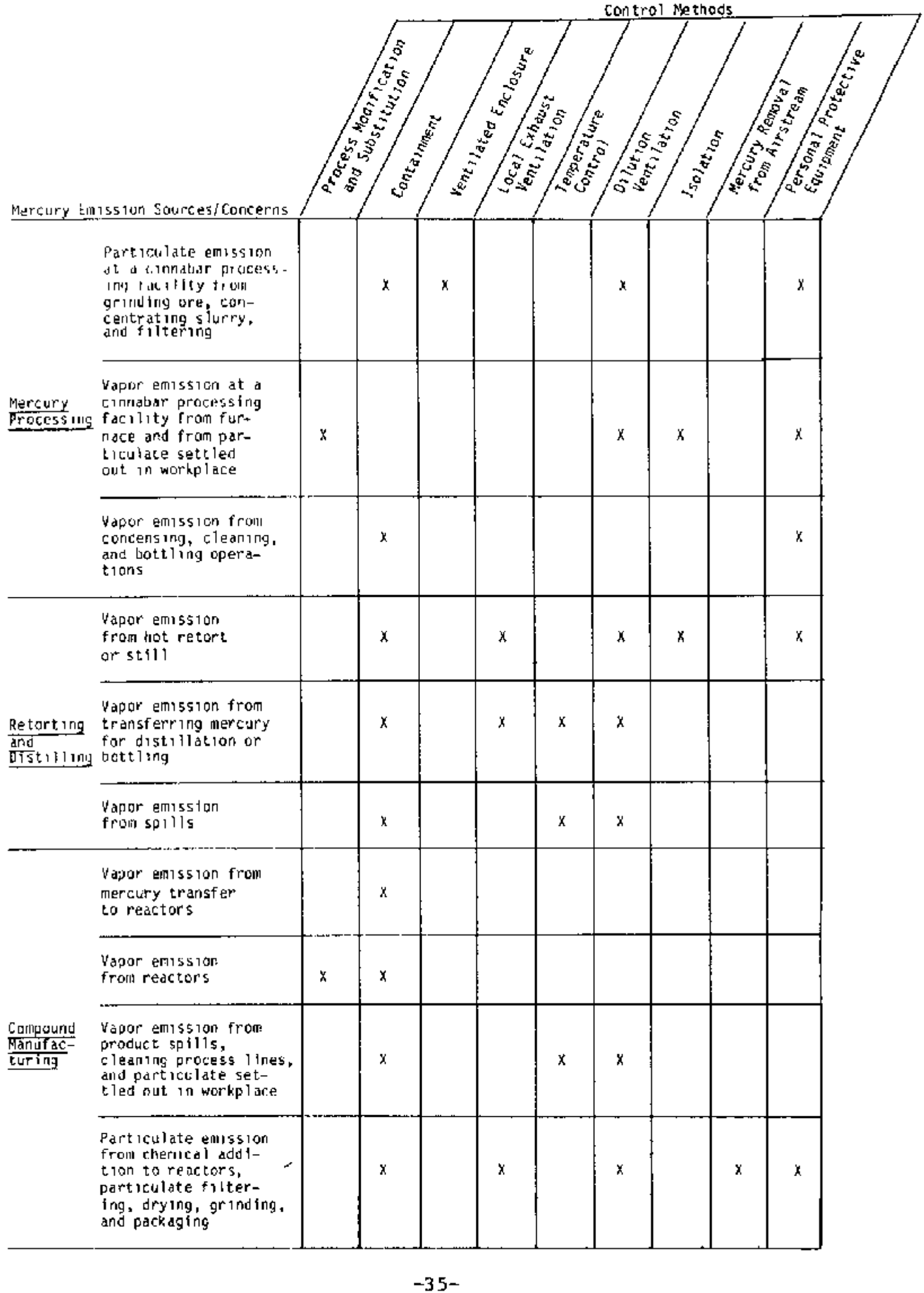




\section{CONTROL METHODS}

\section{A ENGINEERTNG CONTROLS}

\section{Process Substitution and Modification}

Several plants have been able to substitute new processes for those that previously involved the use of mercury. This is usually possible only in Industries that usc mercury as a means for production rather than as a raw material for production (1.e., 1ndustries that use mercury as an electrical contact or electrode such as the chlor-alkali, electroplating, and electrical standardization industries). This technique has the advantage of completely renoving mercury from the workplace, provided that old contamination ts elimimated. Unfortunately, product requirements, process restrictions, and cost constraints, may limit the use of substitution as a control measure for mercury exposure. As an alternative, other plants have modified the use of mercury in their production operattons to significantly reduce mercury emlssions and eliminate the need for implementing cosily ventilation controls. This section details several aubstitution and pracess modification controls implemented to reduce or eliminate mercury vapor or particulate emission.

a. Subsilution for Mercury Electrical Contacts Pools of mercury or "wells" are used as electrical contacts for rotating drums and rollers in the electroplating industry. The use of the pools for the rollers in the treating process at one plant surveyed has been eliminated by substituting rotary contact devices.

Representatives at this plant detexniod that the mercury wells that are used as cotitinuous contacts for rotating ahafts in the "treating" process were a source that contributed most to the high mercury vapor concentrations in the production area. Plant engineers found that heavy-duty rotary contact devices were commercially available that were capable of providing a current of up to 2,000 amps to a rotating shaft. These devaces completely eliminated the need for mercury wells in the treating process and therefore eliminated mexcury contanment problems in the Treatment Room.

Two types of rotary contact devices are used at this facility. One type is the TWECO Rolo-Ground (F士gure $\mathrm{V}-1$ ), a heavy-duty rotary grounding device typically used in welding applications. It consists of an annular head and a shaft (both made of copper) that fit around the rotating shaft and have a tensionaadjusting bolt to maximize operating efficiency. Each head and shaft is provided with grease-cup lubrication. The plant formerly used copper-containitg grease as a conductive lubricant between the Roto-ground and the shafi. They currently use a graphite-containing grease that provides the same conductance while reducing housekeeplng probiems typacally associated with the copper grease. Up to three heads can be used on each end of the rotating shaft, depending on the range of electrical current desired. The total cost of substituting Roto-grounds for all of the mercury wells in the Treatment Room was reported to be approximately $\$ 9,000$. 


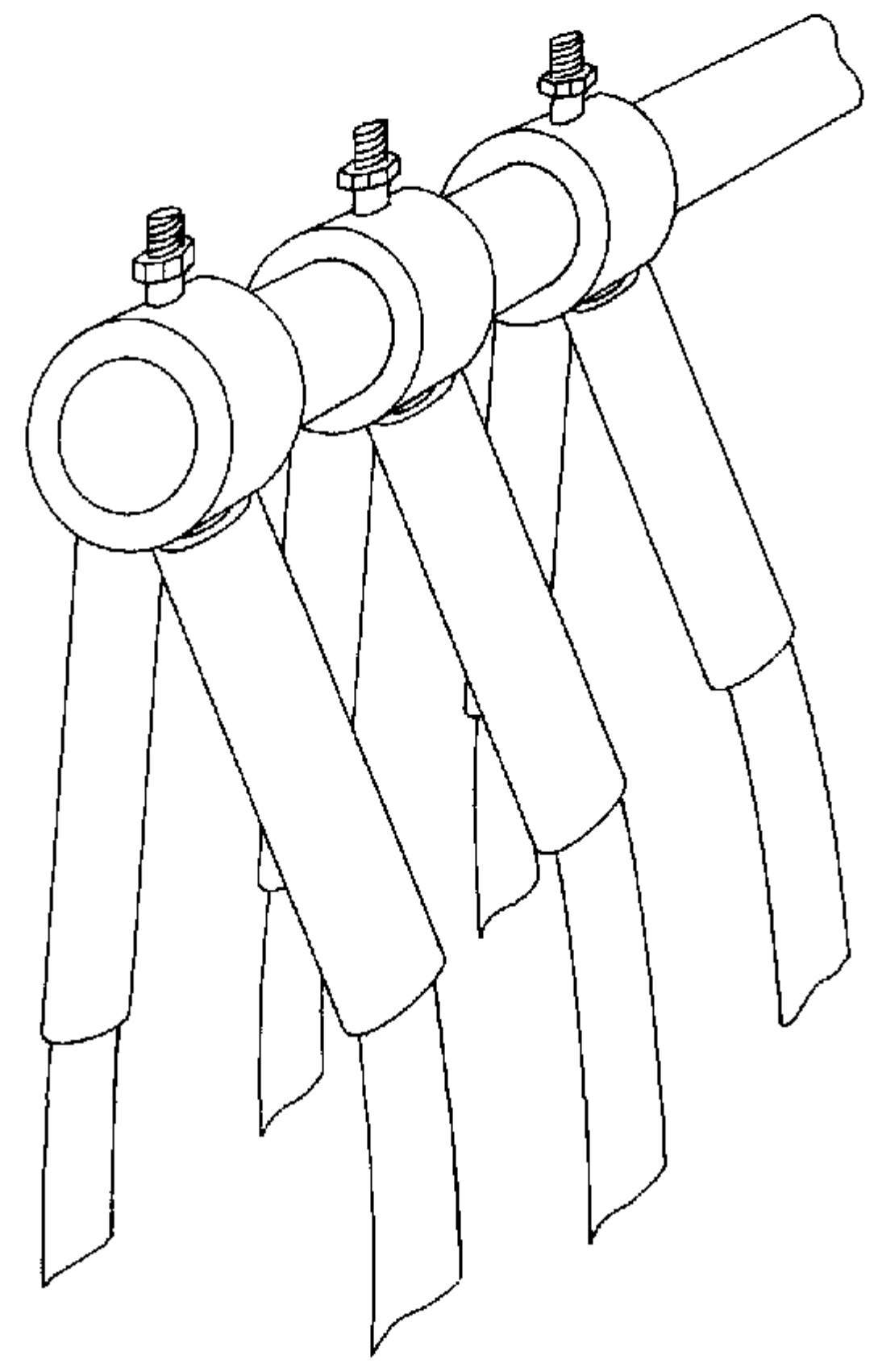

Fugure $V-1$. TWECO Roto-Grounds Mounted on a Rotating Shaft. 
The ather cype of rotary cantact device used is a Japanese-manufactured NR series collector ring contact which is simflar to the TWECo Roto-ground. the contact is made of a series of SAE 40 bronze rings that fit over the rotating shaft. The number of rings used depends on the range of current desired. Each ring has a set of internaly mounted metal brushes for continuous contact with the shaft. The plant has found that this rotary grounding device performs better than the Roto-ground, but it is not possible to fit all treating machines with the NR series contacts due to physical limtations. The plant engineers are currently evaluating another series of all-purpose collector rings with copper alloy brushes. These units are manufactured fn the United States by Industrial Electric Reels.

The rotary contact devices provide effective electrical contact for use in the treating process. Not only do they eliminate the need for using mercury in this process, but they have ellainated the costs previously incurred at this plant for replenishing mercury lost from vaporization in the mercury we11s 1 t the Treatment Roon The rotary contacts do not, however, provide electrfcal contact sufficient to handle the high current demands for the rotating drums used for the initial electroplating process.

Mercury 16 also used as a contact in the electrical standardization process. The calibration of current shunts (resistance devices used to measure current) requires the use of high current supply (approximately 10,000 amps). One electrical standard malufacturer generates this current using a series o[ up to 60 balteries called a "battery board." These batteries are kept in a separate room. Varying currents are generated by adjusting contacts in $a$ mercury pool so that the proper number of batteries are connected in series. The battery board is currently being replaced by a new current generator at an equipment and installation cost of approxtmately $\$ 6,000$, which will eliminate the need for a mercury pool because the generator is equipped with a current regulator.

Substitution for mercury use in the chlor-alkali industry, one of the largest mercury-consuming industries, is an ongoing effort in which new expanded technologies are continually developing. New types of chlor-alkali cells, such as diaphragm cells, are currentiy in operation in some plants. Most facilities still find mercury cells to be the most cost-effective means of chlor-alkali production despite the expenses incurred for controlling the mercury vapor generated. Additlonal technological development coupled with stringent occupational and environmental health concerns may continue to provide an incentive for eliminating mercury from these plants, however.

b. Dental Amalgam Handling Modification

A major improvement for operatory convenience and mercury control in the dental 1ndustry has been the development of preenclosed dental amalgam capsules. Traditional formation of amalgans for use in dental applications anvolved open-ali nixing of mercury and alloy powder. The mixed amalgan was aften mulled by hand to obtatn the proper consistency (by removing excess mercury). Handling amalgam in this manner increased the potential for exposure of dentists and dental assistants to mercury vapor in the amblent anr of the dental offlce. It also increased the potential for dermal contact with mercury and subsequent ingestion of mercury. Some dent1sts st111 practice this type of amalgam formulation. 
Instead of mixing a spill (drop) of mercury with the alloy powder inside a capsule, a premeasured spill of mercury is enclosed in a sealed capsule along with the proper amount of alloy powder. The process of filling the capsule with mercury is therefore elfminated by substituting the preenclosed capsules. The use of preenclosed dental capsules for amalgam formulation mundmizes the release of elemental mercury to the ambient air.

Dermal contact with the amalgam is also minimized because the proportions of mercury and alloy powder are premeasured at amounts that will form the optimal amalgam. This usually eliminates the need for the worker to mull the amalgam before application, and also to dispose of small excess quantuties of mercury.

DispersalloyR Dispos-a-cap capsuies, manufactured by Johnson and Johnson Dental Products Company, 18 one brand of preenclosed capsules used in dentistry. Each capsule is approximately $31.75 \mathrm{~mm}$ ( 1.25 1nches) long and 15.87 mm ( 0.625 inches) in diameter. There are two chambers in each capsule (F1gure V-2). The upper chamber (a two-piece plastic assembly) contains a predetermined amount of mercury--usually one, but possibly two or three spills. The bottom chamber contalns a steel pestle and the amount of alloy powder required to amalgamate with the mercury. By pulling out the top portion of the top chamber assembly, mercury is allowed to flow through a hole into the bottom chamber to contact the alloy powder. The amalgam is now triturated by agitating the capsule in the "whirly-gig." The pestle ensures proper mixing inside the capsule. After trituration, the capsule is opened by separating the top chamber from the botton chamber. The bottom chamber is emptied into the amalgam well, and the amalgam is ready for application. The capsule is closed and discarded.

c. Particulate Handling Modification

Controlling mercury particulate emissions when charglng mix tanks and reactors can be a difficult problem, especially in batch chemical operations. One battery manufacturer, who uses 15-pound batches of mercurtc chloride in producing $1 \mathrm{ts}$ electrolyte solution for a cathode mixture, is investigating the use of water-soluble plastic bags for mercurlc chloride addition. The plant would purchase the water-soluble bags containing 15-pounds of mercurfc chloride from xts supplier. The worker would be able to dump the unopened bag directly into the zinc-chloride solution where it would dissolve and release the mercuric chloride. The potentlal for exposure to mercury particulate when cutting open the bag would be eliminated. This control would be applicable to many industries (e.g. paint formulation) that use particulate mercury compounds as an ingredient or reactant 1n production, provided that the bag material does not introduce impurities into the process or product, and the mercury can be obtained in exact batch-sized quantittes.

d. Modifications $1 n$ Mercury Processing A large-scale process modification is currently belng investigated by a major mercury mining concern and the U.S. Bureau of Mines. The mine is atcempting to elininate mercury vapor entted from heating mercurtc sulfide in the mercury furnace A hydrometallurglcal process is being evaluated to replace the pyrolysis operation currently in use. The new process involves 


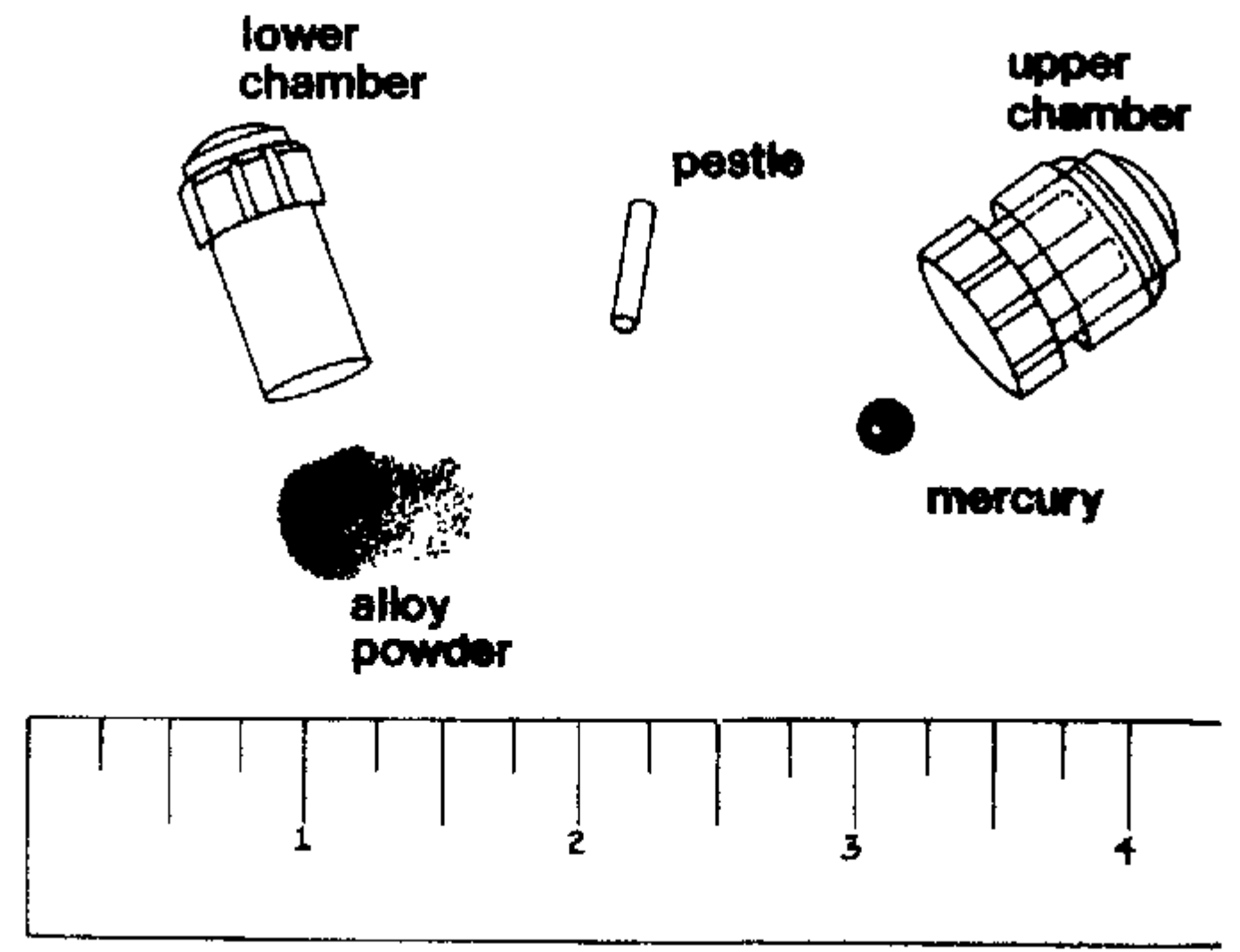

Figure V-2, Duspersalloy ${ }^{\mathrm{R}}$ Dtspos-a-cap Cumponent. 
leaching mercuric sulfide concentrate with chlorine and oxygen at $100 \mathrm{C}$ $(212 \mathrm{~F})$ and $40 \mathrm{psig}$. Mercury goes into solution as mercuric chloride and is then decamposed through ayueous electrolysis into elemental mercury and chlorine. This process modification is currently in the planning stage. If the technology proves successful and the process is put into operation, the major source of mercury vapor emission (the furnace) at the mine will be elfminated Potential exposures to chlorine will, of courbe, have to be controlled in this new process.

e Modifzcations in Mercury Filing Operations Plants producing mercury-filled products are particularly concerned with mercury vapor emission because of the large amount of mercury consumed. In addition, there is typically a larger surface area of mercury exposed to the amblent air than there is in most mercury operations. This 1s because the operation involves a large quantity of production units, each filled with a small quantity of mercury (higher surface area to weight rat 10).

It is difftcult to control the mercury vapor emissions during the fluorescent lamp manufacturing process, since the lamp tubes are heated immediately after the mercury is added, increasing the propensity of the mercury to vaporize. One plant has implenented a major process modification that eliminates this point of emission on the manufacturing equipment used to produce 80-90 percent of the lamps. The process modification is the use of mercury-containing capsules, or "pills," for release of mercury in the lamp tube after the tube has been sealed. The pill is a small, sealed glass Lube (approximately $1 / 2$ inch long and $1 / 16$ inch ith outer diameter) that contalns a specified quantity of elemental mercury. It is manufactured at the plant using a proprietary process. The pill is attached to the outslde of the cathode shield on the mount assembly (FIgure V-3). A thin wire is placed across the pill and Is attached on either side to the cathode shield.

of the two mount assemblies used in each lamp, only one contains a mexcury pill. When the exhaust tubes are tipped-off, the pill is contained inside the sealed lamp tube. Mercury is released tinto the lamp tube by splitting open the glass pill at its center.

The use of the mercury pll results in the complete enclosure of the mercury addition process. It also results in a reduction in mercury usage because the enclosed release process reduces mercury waste typleally associated with the mercury addition operation.

Mercury vapor emission from the exhaust machines (where mercury is introduced into the glass tubes) In the fluorescent lamp manufacturing process may also be reduced using a mechanical device called a "tube catcher." This device immed lately removes and contains the mercury-contaminated glass tips that result alter the exhaust tubes are sealed closed by the flame. The tube catcher is a mechanically operated movable chute that reaches up and out from the center of the exhaust machine and catches the hot glass tip released from a compression piece after the exhaust tube is sealed. The tip falls through the chute into a disposal container (Figure $V-4$ ). A water level is maintalned in the container to reduce mercury vaporization. The total cost of implementing the system on all of the exhaust machines at this 


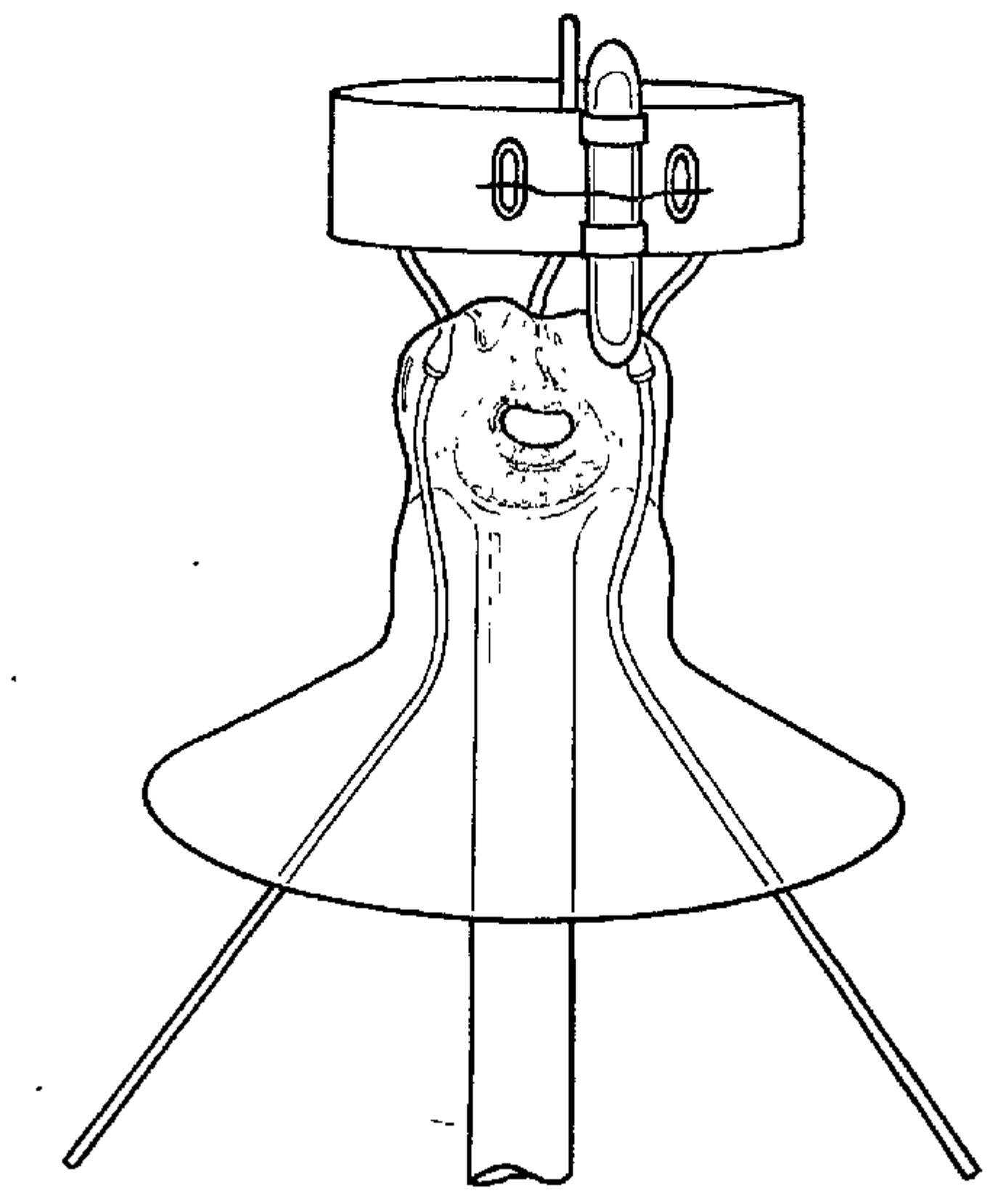

Figure V-3. Mount Assembly with Mercury Pill. 


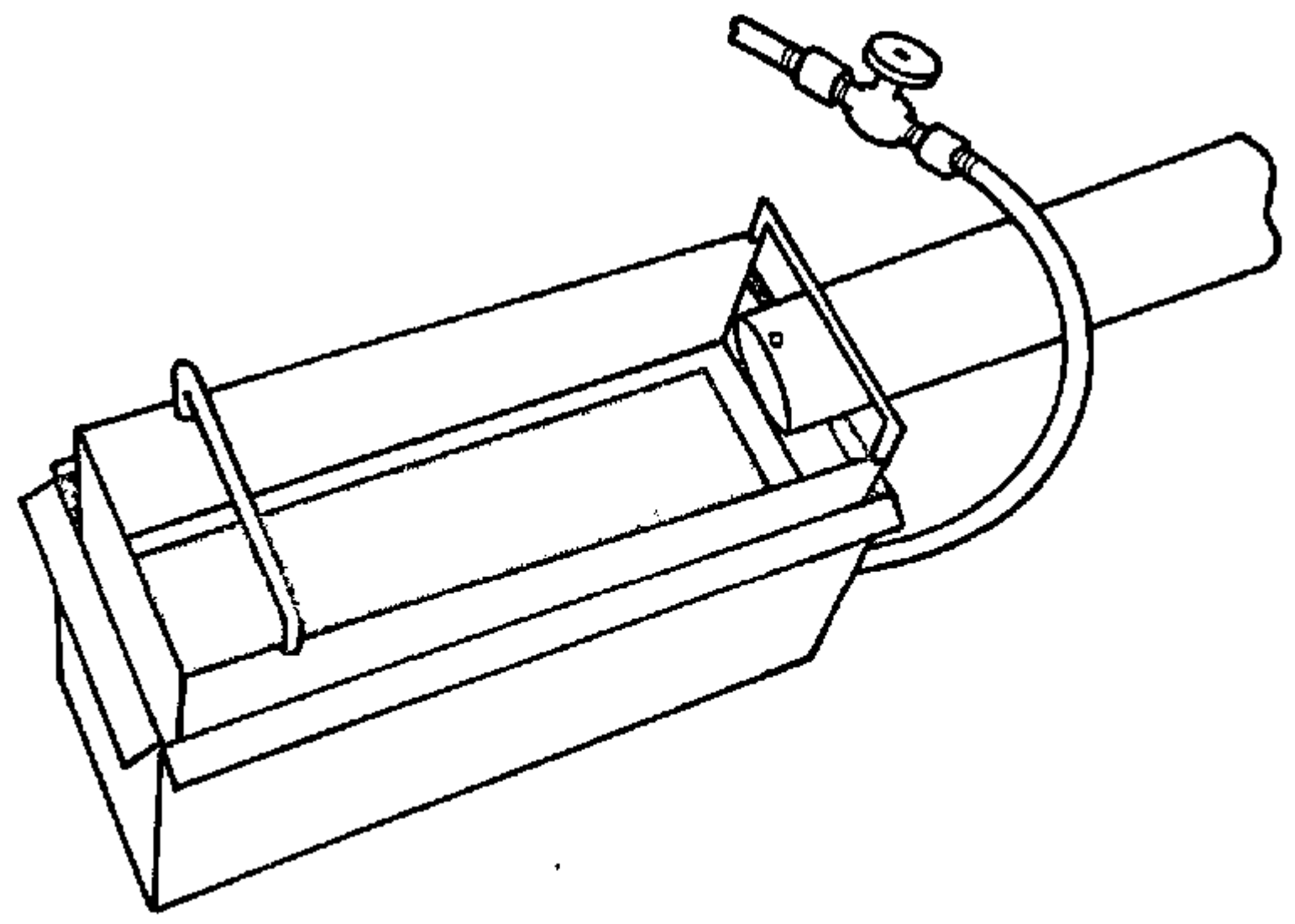

F1gure V-4. Exhaugt Tube Tip Contafner. 
plant was $\$ 80,000$ in 1975 . Tn addition, a nitrogen blow system and extended compression holders were installed on each exhaust machine at a total cost of approximately $\$ 10,000$. The extented compression holder is a spectal silicone rubber seal used to connect the exhaust tube of the lamp to the mercury diffusion pump. It forms an effective seal for the vacuum at high temperatures. The nitrogen blow system was designed to clear out any residual mercury in the compression piece. As the tube catcher rises to collect the glass tip, nitrogen is injected through the tip and mercury is blown into the chute.

Handling mercury to be used in filling operations is also an exposure concern. One thermometer manufacturer is currently developing a new mercury addition system to supply mercury to 1 ts mercury-filling equipment. The new system wil eliminate the need for a worker to transfer mexcury from the purification area to the present addition system because both the purification and addition operations will be performed with the same equipment.

The present mercury addition system is belng replaced by an aspixator system that will provide a purer quality mercury to the flller. Th1s new system consists of an aspirator jar (with a clouble-holed atopper at the top and a mercury feed tube at the botton) and an oxygen and argon injection system. The system w1l work in the following manner:

o Mercury 15 poured into the aspirator jar and the jar 1 s capped with the double-holed stopper.

- The jar is evacuated through one of the stopper holes.

- Oxygen is pumped through the second stopper hole and bubbled through the mercury to oxify (purify) it.

- The oxygen 15 shut off and the vacuum is released.

- Argon is injected through the first stopper hole to keep air (uith potentral contaminants) from coming in contact with the mercury.

o The mercury stopcock valve is opened, allowing mercury to flow out of the aspirator and into the filler.

A sumary of the "Process Substitution and Modification" controlo studied is presented in Table $\mathrm{V}+\mathrm{L}$.

\section{Containment of Mercury Sources}

Containment, as a workplace control, is the enclosure of mercury and mercury-containing products and wastes $1 \mathrm{n}$ order to reduce the potential for the release of mercury into the workplace. Many methods of contalnment are used in the mercury industry. Mercury transfer and addition operations are contalned by moving elemental mercury through closed systems using gravity, vecuum, or positive pressure. Particulate mercury is moved in a similar way using pneumatic transfer devices. Mercury filling and mix operations are contained using special dispensing equipment designed to minimize handling, spillage, and waste. These methods are described as follows: 


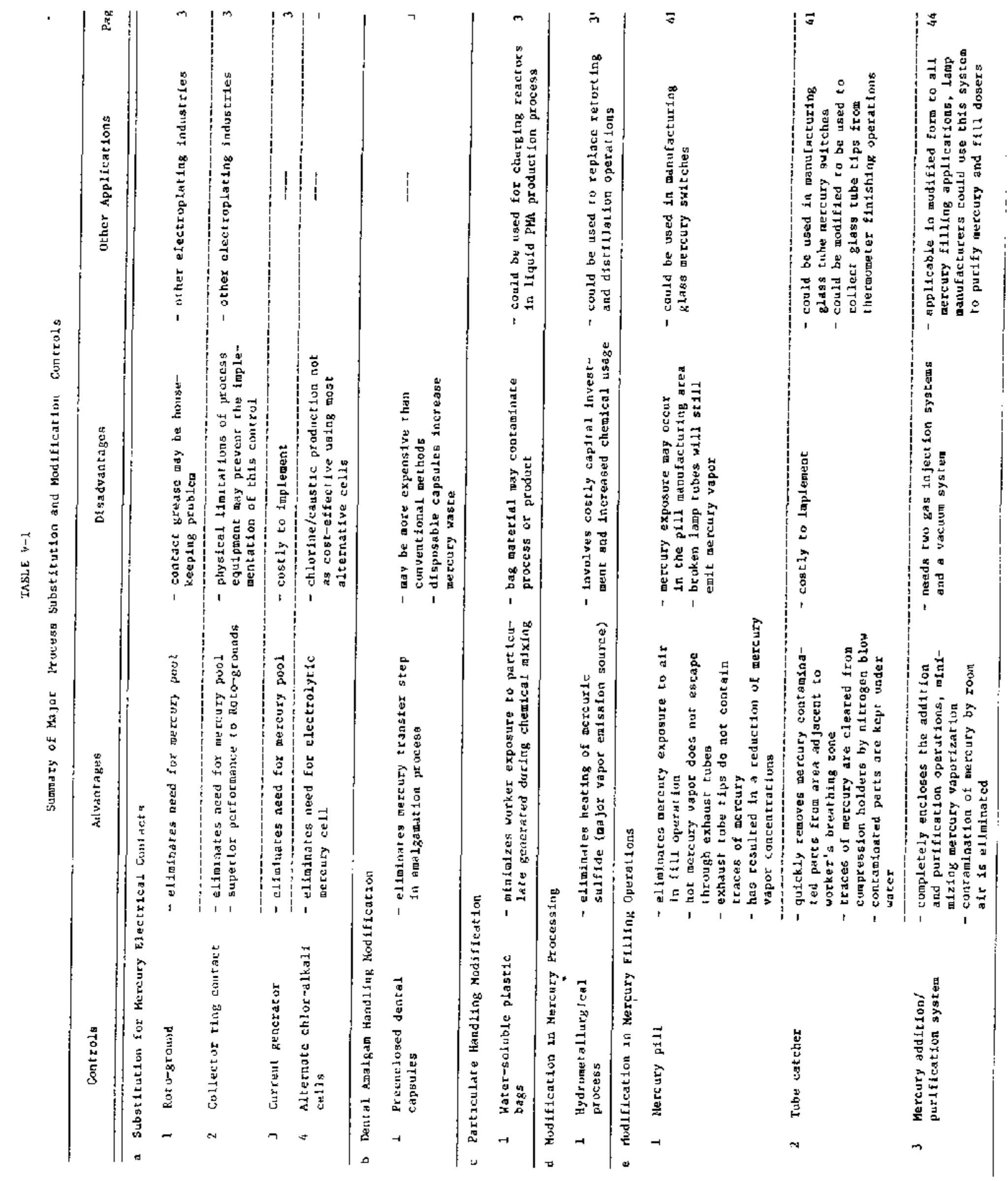




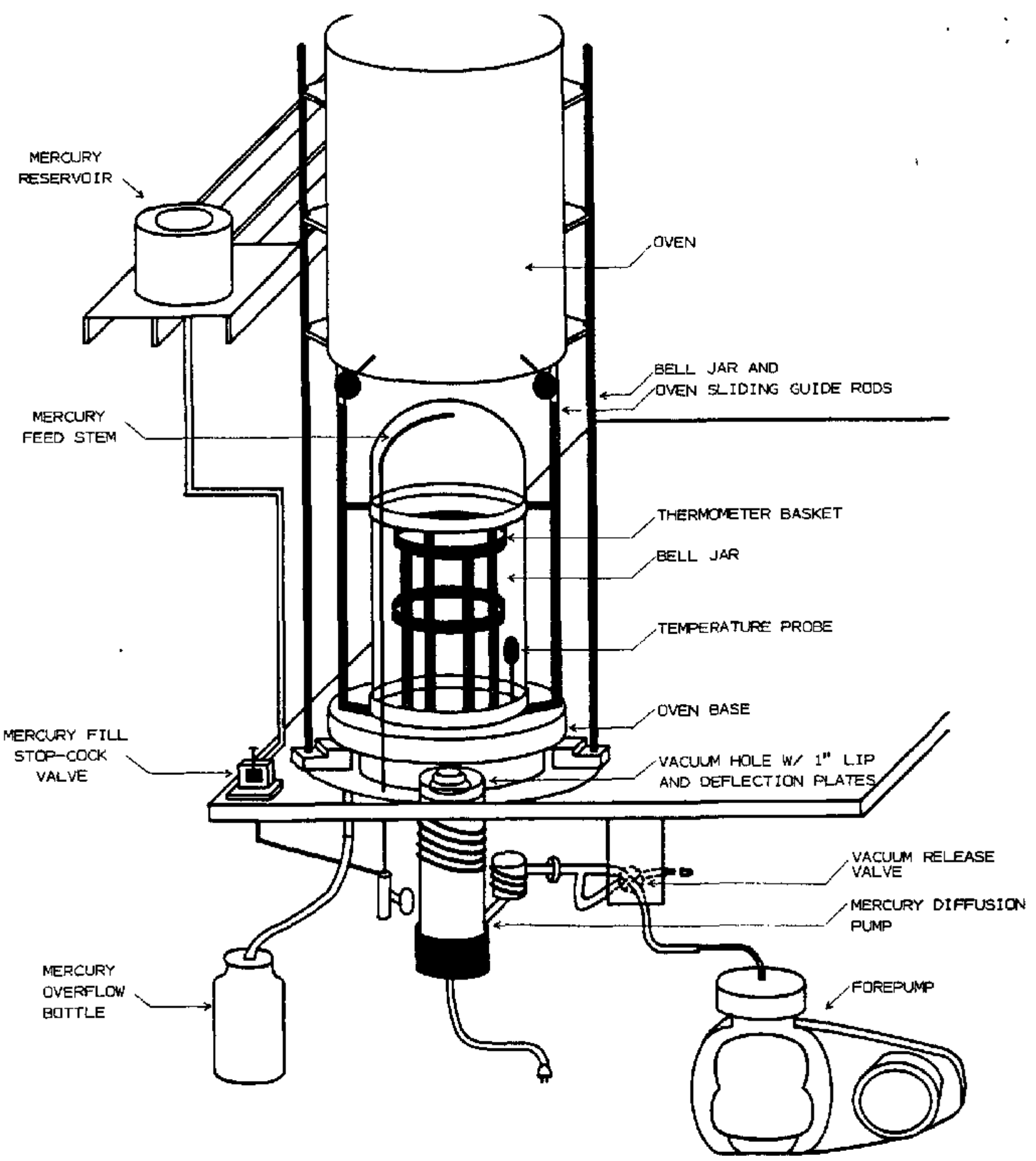

Figure V-5. Srhematic Dtagram of the Mercury Filler. 
a. Enclosed Systems for Liquid Mercury Transfer

Manufacturers using mercury-fililng operations have developed many different contanment controls. This is particularly true of producers of temperaturesensing Instruments. One of the most elaborate contalnment systems is a vacuum filling device used by one thermometer manufacturer to fill glass tubes. The filler consfsts of a bell jar, a vacuum system, an oven, and a closed mercury addition system (Figure $\mathrm{v}-5$ ).

The bell jar rests on an annular-shaped ceramic base set on a bench. By lifting the bell jar, pans of thermometera can be set inside the annular base. The bottom of the pan rests on a set of deflection plates that cover a hole leading to the vacuum system These plates prevent liquid mercury from falling into the vacum hole. There is also a l-inch, circular metal lip around the plateg to prevent mercury from flowing from the bell jar base into the hole. When the bell jar is lowered, it sets into a seal at its base, whlch prevents leaks when the vacuum is drawn.

The vacuum is drawn thraugh a sertes of two pumps consfsting of a Cenco HYVAC 7 fore pump (run by a $0.5-h p$ Dayton motor) and a mercury diffusion pump. The fore pump is a standard vacuum pump that is capable of drawing a vacuum down to 100 aTorr ( 100 um of mercury). The pump has a mercury trap at the 1ntake. The mercury diffusion pump takes over at 100 mTorr and is capable of drawing a vacuum in the bell jar down to 1 mTorr (1 um).

An oven is used to renove moisture from the glass tubes and to assigt in drawing a vacuum. The oven consists of a hollow ceramic cylinder with a stainless steel shell and a heating element. It is lowered over the bell jar and seals against the ceramic base.

The mercury addition systen is the major control component in the mercury filler. It is a completely enclosed system that, when coupled with the sealed bell jar, mercury deflection plates, and dual vacuum system, helps to prevent the escape of mercury liquid and vapor loto the workplace. Mercury is contained in a covered stalnless steel reservoir mounted above the bell jar. One reservair is used to supply three mercury fillers. Stainless steel tubing comects the reservoir to a stopcock valve mounted below it on the bench. From the stopcock, additional tubing leads down under the bench and up through a mercury feed stem inside the bell jar. By opening the valve, mercury flows thraugh the tubing to the feed stew and into the top of the bell jar where $1 t$ falls into the pan below in preparation for vacuum filling.

At one mercury switch manufacturing plant surveyed, a mercury filling machine is used that has an enclosed addition system that completely eliminates any manual handling of elemental mercury during the fill operation. This concrol centers on the use of mercury containers designed by Bethlehem Apparatus Company. These contalners (Figure $\mathrm{V}-6$ ) are constructed of stainless steel and are capable of holding 800 pounds of mercury. Each container is mounted In a steel frame that has welded angle-iron attachments to allow for iffing and moving by forklift. The plant recelves the filled container of mercury from the supplier and puts it into service by lifting it on top of a holding frame using a forklift. The supply tube from the container is connected to 


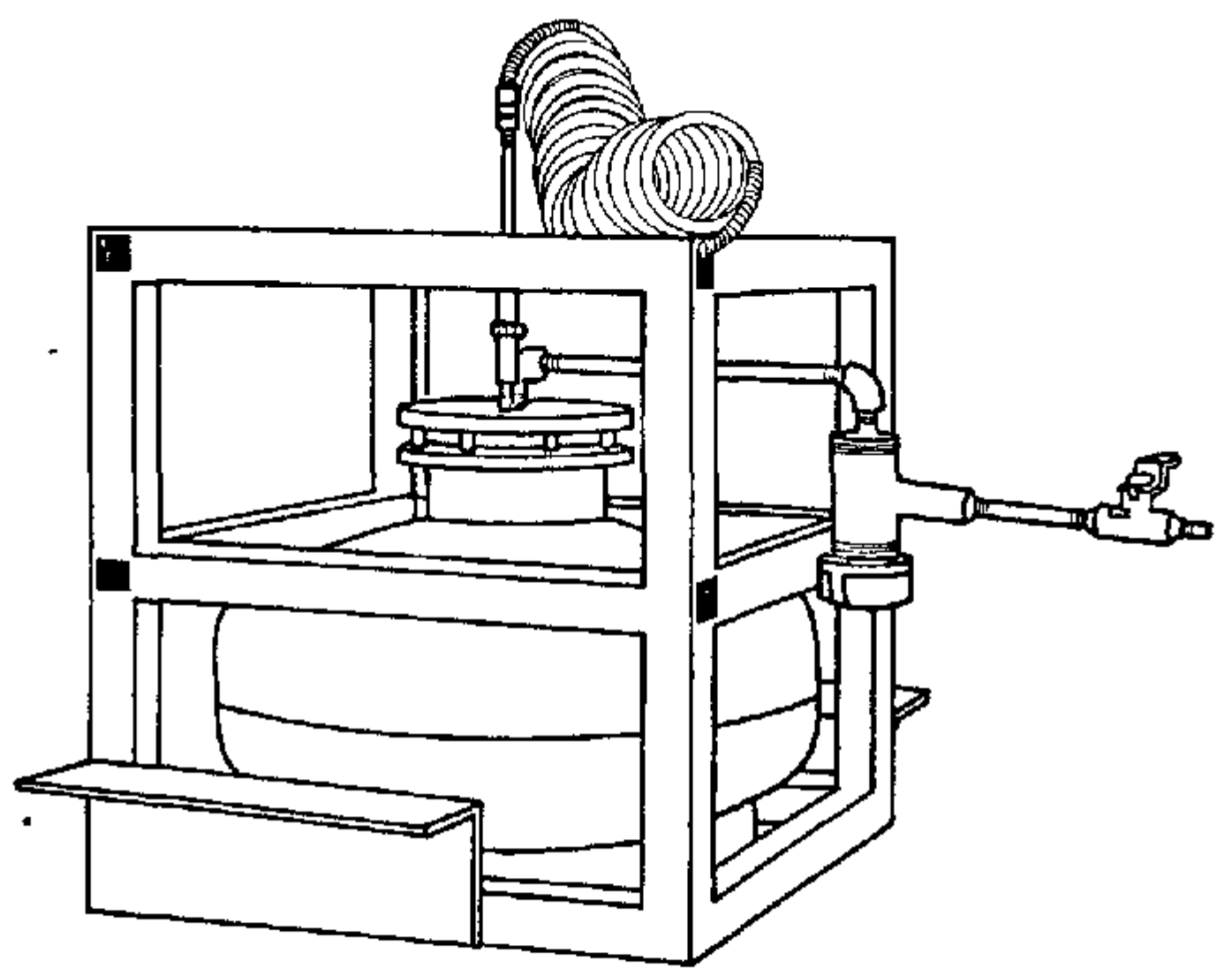

Figure V-6. Mercury Storage Container.

the inlet of the mercury hold tank at the welding machine. Another tube connects the contalner to a tank of pressurized helium. By opening a valve on the supply line, mercury flows into the hold tank under the pressure of the hellum. Transferring mercury from 76-pound flasks to the hold tank has been eliminated, thereby eliminating a potential mercury vapor emission source. Th1s completely contained system could be applicable to most mercury filling operations.

Containment of mercury in process streams is accomplished through the use of effective gaskets and seals. It is important to use materials that will minimize or eliminate leakage normally caused by thermal expansion, contraction, and wear. Single or double mechanical seals should be used on pumps or other noving equipment, depending on the application.

Chlor-alkall factlities are particularly concerned with seals and gaskets because of the extensive piping network and large number of electrolyctc cells in the operation. Sealing materials are used throughout the mercury 
cells to prevent the escape of chlorine gas and mercury vapor. One plant surveyed uses gaskets to seal the seams where the cell covers are clamped to the sides of the cell channels Diaphragm seals are used at the points where the lead-in posts of the anodes penetrate the coll cover. Ethylene-propylene-diene monomer (EPDM) is used in thia service. It is resistant to alkalies, oxidizers, and high temperatures.

At the same plant, special sealing matertals are used on the decamposer and the mercury sump. The seam between the flanged top of the decomposer vessel and the steel cover bolted to th requires a sealing material that will not fall when subjected to the heat of reaction $1 n$ the vessel. Asbestos gaskets are used in straight mercury service. Where chlortne is also present, neoprene or Hypalon ${ }^{R}$ gaskets must be used. Sealing material is used to seal the connection between the mercury sump and the mercury pump base-plate so that vapor fron the hot liquid mercury will not escape into the ambient alr. All flanges and valves in the mercury system are similarly sealed.

Another chlor-alkali nanufacturer uses continuous, two-ply rubber covers on 1ts mercury cells, The covers are manufactured by B.F. Goodrich and are designed to last as long as the anodes (approximately 18 months). Although there is 11ttle possibilicy of mercury vapor escaping from the cell during normal operation because of the vacuum created by the chlorine gas removal system, the covers provide an effective seal that reduces mercury vapor emission when starting up or shutting down a cell. The copper anode posts are sealed with rubber gasketing materfal at the points where they penetrate the rubber cover. Plant engineers are currently process testing the use of clear Teflon cell covers. They are more expensive that the rubber covers but are expected to last longer.

The mercury system on each cell has compressed asbestos gaskets at pipe and pump connections. The plant is gradualiy changing over to nonasbestos materials (mostly Teflon). These gaskets effectively prevent mercury leaks during operation, however, leaks perlodically develop during akutdown because of contraction at pipe flanges due to cooling.

b. Enclosed Systems for Particulate Mercury Transfer

Unt aperations typicaliy requiring containment control include blending, drying, grinding, sizing, transferring, and packaging.

A combined mercurte oxide grinding and packaging operation at one chemeal plant uses a particulate transfer systern operated under vacuun. This reduces mercury particulate escaping from flanges and valves and elimanates the need for manually transferring dry mercurtc oxide between the grinding and packaging stations. Fine dust generated at the grinder is separated from the oxide product by a cyclone dust separator. The product-size oxide particles are spun to the outside of the cyclone and are channeled through a line to the packaging station. The fine dust falls through the center of the cyclone into a hopper on the botton. It is emptied perlodically into fiber drums lined with plastic bags When enptying, the plastic bag is taped around the bottom of the collection hopper so that the valve is opened the dust 1.8 contalned in the bag. 'She discharge from the vacuum pump, after going through another cyclone dust separator, is exhausted to the roof. The collected 
dust is removed once a week and is reprocessed through the grinder. In a similar operation at another chemical plant, the loading drums are sealed against the packaging equipment. Powdered PMA is packaged in plastic-lined drums underneath the rotary valve and delfvery chute on the baghouse particulate separator. The plastic liner is connected to the chute so that the powder will not disperse into the alr while a drum is being filled.

Materials handing methods designed to contain mercury particulate are also employed in amalgam mixing operations. One battery manufacturer has reduced mercury vapor concentrations in 1 ts amalgamation operation through the use of special material containers designed to complement the enclosed blending operation. The particulate contałner, or pad, is a covered confcal bin with a spring-closed slide gate on the top cover and a handwheel-activated butterfly valve on the botton (Figure V-7). These pods can be transported on carts with roller hearing supports and can be maneuvered tnto position above or below mix equipment by a hoist. Material is intraduced to the pod through a flanged delivery chute that is inserted through the spring-closed sifde gate and attached by fastening quick-release clatups to the flange of the chute. Material is removed from the pod by lifting the pod over 1ts delivery point and opening the butterfly valve. The delivery point is usualiy a covered hopper that feeds a screw auger. These hoppers have openings in the top that are just large enough to accommodate the mipple below the butterfly valve at the bottom of the cone. The benefits associated with the use of these pods are (1) reduced exposure to amalgam powder because the powder Is within a closed system and (2) less manual handing of materials.

c. Containment of Mercury praducts and Wastes

The most common contalnment control for reducing mexcury vapor emission is the covering of mercury-containing products, components, and subassemblies as they are completed. At most plants studied, small mercury-containing icems such as anodes, cathodes, cells, thermometers, and switches are stored in covered contafners for transfer and storage.

Handling mercury-contalning wastes is an fmportant aspect of any mercury operation. The waste must be contained to reduce mercury vapor emission, and $x$ must be disposed of proper1y. Effective waste containment systems $r$ emove and contafn the waste at its point of generation.

The exhaust tube tap contannment systems used by one lamp manufacturer surveyed are good examples of mercury waste containment. The exhaust tube tips discarded during fluorescent lamp manufacturing contain small amounts of mercury. Since the cube tips are hot at the time they are diacarded, there Is an Increased potential for emission of mercury vapor. Two types of tube catching systems are used to reduce the mercury vapor generated. The first type is a vacuum system in which a 4,500-cfm (design speciflcations) blower draws the tube tips through several 4-1nch collection pipes to a cyclone separator. The tubes enter the collection pipe by falling into discharge chutes located on each end of the lamp at the tube sealing station of the lamp mantifacturing machine. As the tubes enter the cyclone, they are separated from the airstream and fall tnto a 55-gallon drum. The exhaust airstream from the blower (mounted on top of the cyclone) flows through a dust 


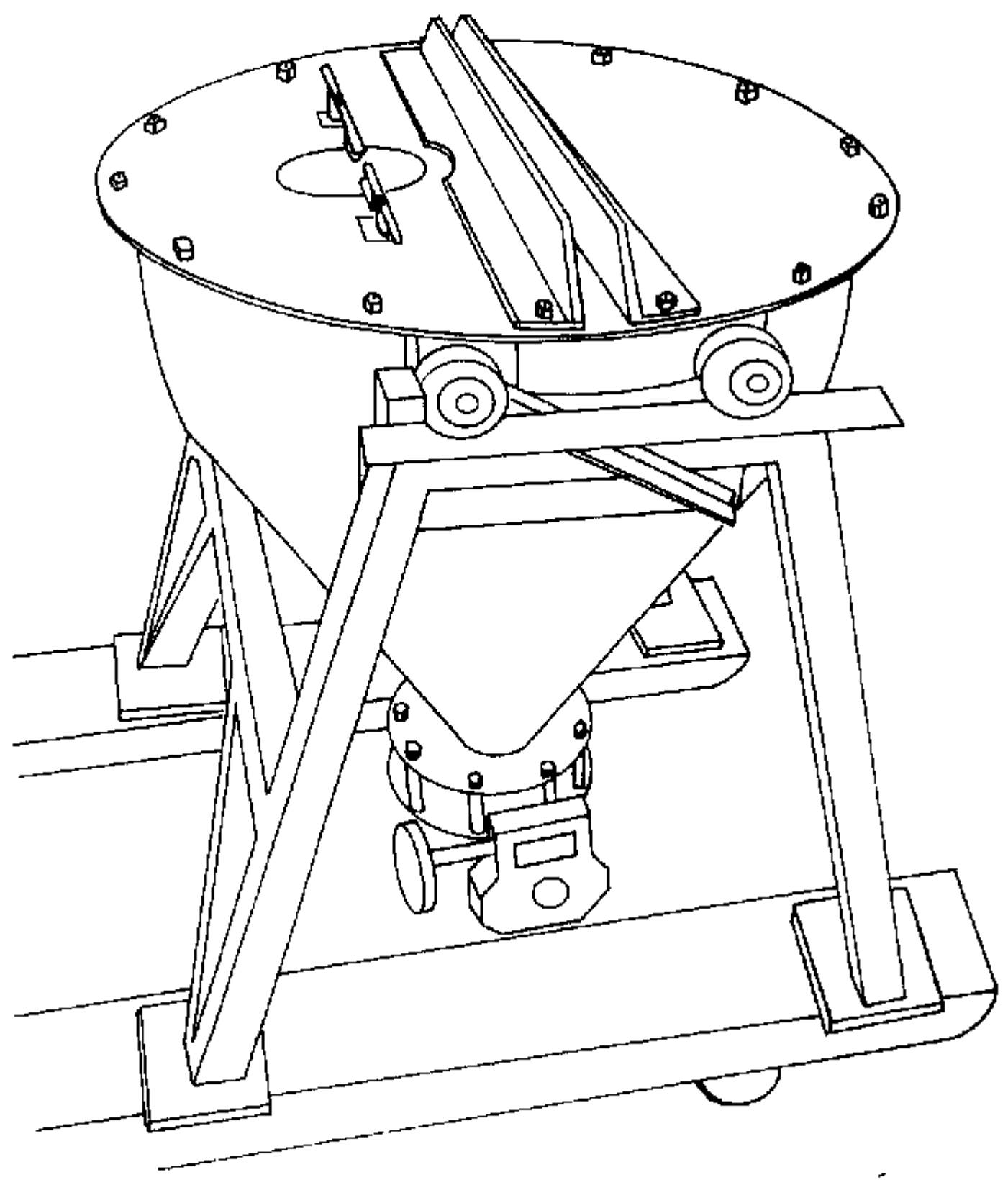

F1 gure V-7. Material Transfer Container (Pod). 
separator before being vented to the roof. The cyclone has a flexible discharge duct that connects to a cover clanped onto the 55-gallon drum. The system is entirely enclosed When the drum is filled to capacity, the cover is unclamped and the drum is transported to a central refuse collection polint.

The second type of tube catcher is a gravity system. Exhaust tube tips fall into a discharge that leads to a covered bucket on the floor below. The bucket is connected to its cover by a seal-tight clamp. Buckets are emptied every 2 or 3 days.

d. Contamment of Mercury Using Water and Ctemtcal Suppression When mercury-containding waste is not completely sedled $3 \pi$ a drum or other waste container, it should be kept under a level of water (usually 5-6 Inches).

Water serves to suppress vaporization of mercury in the waste. Widely applied across all mercury-using industries, water supression is a simple mercury vapor control that is used for the following:

o scrap amalgam in the dental industry

o reject materials in the battery induscry (anades, cathodes, chemical mixes, and cellis)

o exhaust tube tips in the fluorescent lamp industry

o broken thermometers

o reject and broken mercury switches.

Water may also be an effective control for reducing mercury vapor emission frow elemental mercury used as a contact in electrical processes. The inlet and outlet boxes of electrolytic cella gre both sources for the potential escape of mercury vapor. At these points, mercury heated it the electrolytic process passes in and out of the cell by flowing through submerged weirtype gates. Malntalning water over the mercury in these boxes helps suppress mercury vaporization. However, as the water is heated due to contact with the hot mercury, mercury vapor may escape more readily. one plant har solved this problem by ingtalling recirculating, chilled water aystems, one for the inlet boxes (F1gure V-8) and one for the outlet boxes. Each systen consists of a surge tank, a 240-galion-per-minute pump, a chiller unit, and a manffold plping system that circulates water to each cell in parallel. Water from the chiller enters one side of the box, flows over the mercury, and exits through the other side of the box The system supplies 20-30 C (68-86 F) water over the mercury at all times.

In addition to water, other chemicals have been found to suppress mercury vaporization. Mercury vapor emission from the concentrate at a mercury mithe was significantly reduced using sodtum sulfide $\left(\mathrm{Na}_{2} \mathrm{~S}\right)$ as a mercury vapor suppressant. At the grinder feed 1 in the processing mill, ore from the feed 


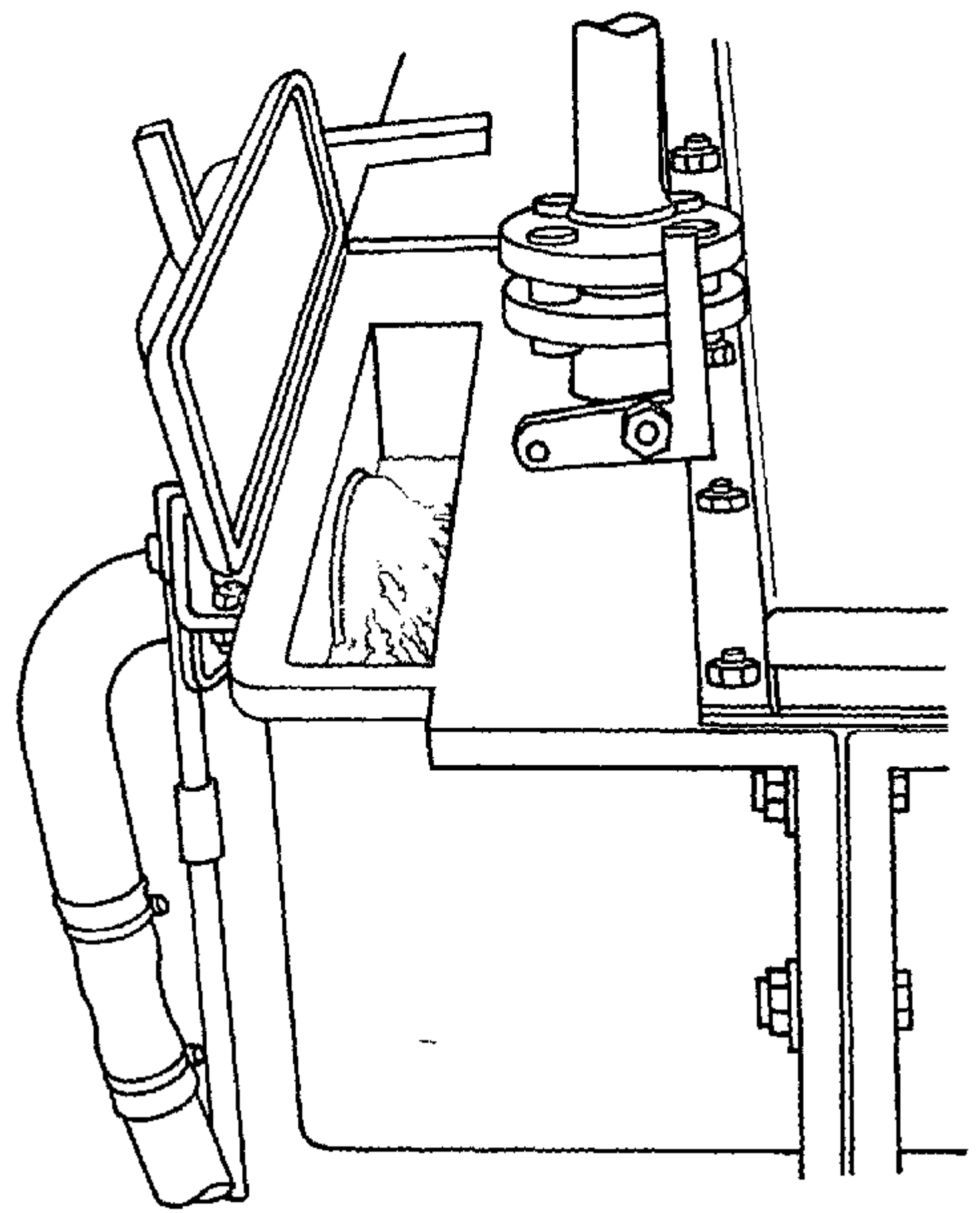

F1gure vag. Inlet Box with Lid open showing Waterflow. 


\section{mill Discharge}

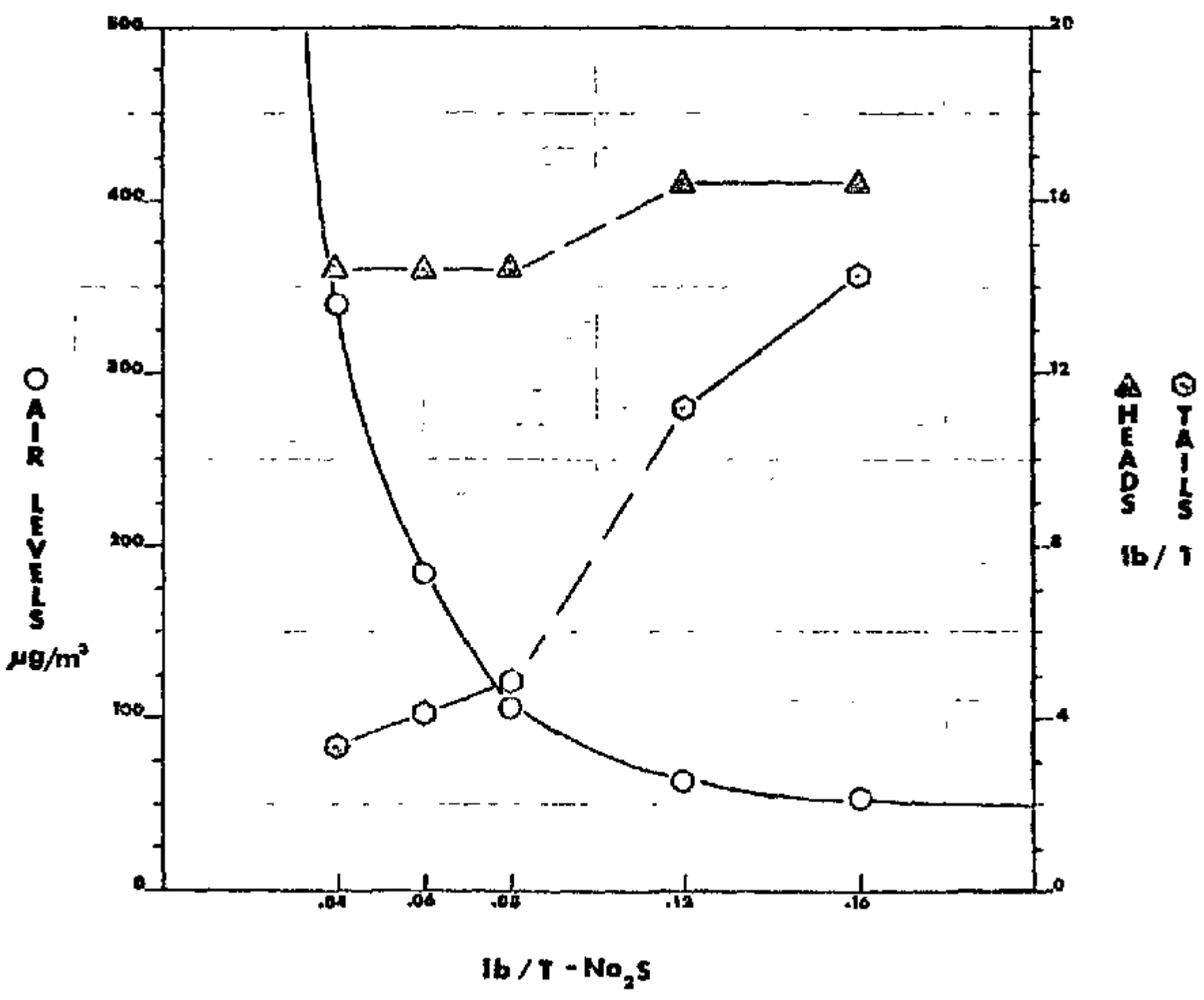

Figure V-9. Mercury Vapor Levels, Heads (Concentrate Production), and Tailing Production as a Function of $\mathrm{Na}_{2} \mathrm{~s}$ Addition.

Reference. Plant drawing from stte visft 
conveyor comblnes with overuized milled ore returned from the cyclone separator. Plant representatives have found that the addition of aqueous Nas helps to suppress the gencration of mercury vapor at this polnt. Experiments conducted by the safety enguneer have shown that mercury vapor concentrations are inversely proportional to the $\mathrm{Na}_{2} \mathrm{~S}$ addition rate (Figure $\mathrm{V}-9$ ). The problem, as can be seen on the graph, is that increasing the addition of $\mathrm{Na}_{2} \mathrm{~S}$ reduces mercurlc sulfide flotation and therefore increases the taf1ings losses. There is a tradeoff between the handling costs of tallings and mercury vapor control, and the plant has found the equilibrium point to be the addition of $\mathrm{Na}_{2} \mathrm{~S}$ at a rate of $150 \mathrm{cc} / \mathrm{ore}$ ton. This corresponds ta an addition rate of 0.04 pounds/ore ton.

A commonly used mercury vapor suppressant is $\mathrm{HgX}^{\mathrm{R}}$, manufactured by Acton Associates in Pittston, Pennsylvania. HgX $\mathrm{H}^{\mathrm{R}}$ a polysulfide compound that chemically binds with liquid mercury, minlmizing its vaporization. It is used for cleaning work surfaces, equipment, and in mercury spills. A dental clinic is currently investigating the use of sodium thiosulfate solution as a mercury vapor suppresgant to cover waste mercury and amalgam. The effectivedess of this control has not yet been determined.

e. Removal of Mercury Spils

In conjunction with $\mathrm{HgX^{R }}$ usage for cleaning mercury spills, many plants use specially designed spill removal equipment. One fluorescent lamp manufacturer has two cart-mounted mercury vacuum pumps used to plck up mercury spills. The pumps are manufactured by Cenco Megavacs (Central Sclentiflc Company) and operated by 1-hp motors. A rubber hose with an inline percury trap and a l/8-inch copper tube tip is used to draw in the mercury. The narrow diaweter copper tip is used to increase the suction velocity, thereby farilitating the mercury cleanup. The mercury trap has a tap at the bottom through which the mercury is dratned.

Another plant uses two Stokes Model Sc2 vacuum pumps mounted on portable carts for cleaning up mercury spills. Suction is drawn through a flexible rubber hose that has an laline covered mercury trap, plant representatives have been using different filters on the discharge of the pumps to reduce mercury vapor emitted during spill cleanup. It was determined that a series of three AMF CJNO Filters (Model $1 M 1$ ) were needed to keep mercury vapor emissions from exceeding $0.10 \mathrm{mg} / \mathrm{m}^{3}$ during pump operation while cleaning up spills. After further experimentation, it was found that one koby Sentor King 60 falter (NLA Products, West Polnt, Pennsylvania) controls mercury vapor emissions below $0.10 \mathrm{mg} / \mathrm{m}^{3}$.

One dental clinic uses a portable vacuum pump (Gouco Surgical Mfg*) mounted on a small pushcart to remove spills that cannot be reached by the vacuum system located at the operatory bays. Spilled mercury is drawn through plastic tubing to an Inline plastic bottle that acts as a liquid mercury trap. The vacuum pump exhausts through a replaceable fiber filter (not intended to remove mercury vapor). The use of this pump on a mercury apill was found to increase the mercury vapor concentration in the workplace. After vacuuming a spill, mercury collected in the bottle is transferred to a closed container for disposal with other clinfc mercury waste. 
A portable splil cleanup kit may be used for smaller mercury spllls. One k1t (manufactured by Science Related Materials) contalns a sponge, a suction unt, a $3 M 8707$ respirator, and mercury-absorbing materlal. The sponge has a mercury aboorbent material on one side. The suction unit is a handoperated plastlc plece with a mercury trap that is capable of creating enough vacuum to draw a small amount of mercury off a wark surface. The mercury-absorbent material is spread over the splli area to amalgamate the mercury and suppress vapor emission.

Many facilities handing mercury use a more conventional type of induatrial vacuum cleaner that has been specially adapted for mercury use. These vacuum cleaners are mobile, stainlcss steel, can-style units usually equipped with a 1.5-1nch suction hose, vactum pump, inline mercury trap, and vapor or particulate filter. They typlcally provide an airflow of approximately $80 \mathrm{cfm}$ and a maximun vacuum of 70 inches of water. The inline mercury trap is used to collect the mercury before it reaches the vacuum pump. The trap is usually a removable plastic container the size of a small can. The filters used are charcoal and/or high-efficiency particulate alr (HEPA) filters. Charcoal filters are used to remove mercury vapor from the vacuum pump discharge. HEPA filters are effective in removing mercury particulate (oxide, etc.) from the discharge. Filcers must be changed periodically depending on contaminant levels found at the discharge. Manufacturers of vacuum cleaners designed for mercury service include Nilfisk. National Super Service, Mer-Vac, and Dayton.

One plant eliminated the potential for contaminating the workplace (because of mercury vapor breaking through the charcoal filter) by routing, the vacuum pump discharge through a flexible hose to an outside vent.

Facilities requiring frequent cleanup of mercury splils and removal of excess mercury from work surfaces generally employ central vacuura systems. One manufacturer of temperature-sensing elements is particularly concerned whth removing and containing mercury that $i s$ displaced in one of its operations. The plant uses a central vacuum system consiating of a dust separator and a 270-cim Multi-Stage Centrifugal Turbo Air Exhauster, operating at a vacuur of 5.5 inches of mercury. The exhauster is driven by a 20 hp motor. The syatem has eight vacuum inlets in the building, each equipped with 2-inch flexible hoses. Each inlet has a cylladrical mercury trap with an internal baffle. The baffle prevents elemental mercury from belng drawn into the vacuum system.

f. Sealing Work Surfaces and Floors to Prevent Mercury Fenetration

To factlitate mercury removal by vacumming or cleaning and to prevent mercury penetration, certain materiala are used for work surfaces. The materials used are usually smooth, 1mpermeable, and free of cracks and gaps. Permeable surfaces such as wood allow mercury permeation, creating a continuous mercury vapor emisston source. 
Worktables used by one thermometer manufacturer surveyed have been designed to minimize mercury absarption and spillage. All work surfaces are made of stafnless steel to prevent mercury permeation. Tables where workers store thermometers have efther half-inch lips around the edges or gutters along the sides to contatn the mercury droplets and to prevent them from falling off the table. The gutters have a drain hole through which mercury may be removed. A11 table legs are caulked at the floor to prevent mercury from collecting under them.

To reduce mercury permeation into cement floors, a 1/4-1nch coating of epoxy resin (extended with a fine aggregate) has been applied to the basement floor of the cell room at a chlor-alkall plant. The coating, manufactured by both Conchem or Permachem, is applied by troweling, like cement. Cracks between floor section jounts are filled wth an epoxy compound containting a finer aggregate, This compound has a higher elastictty than the floor coating and allows for expansion and contraction between floor sections, thus preventing the formation of cracks. The compound is avallable from the same manufacturers who make the floor coating. Another chlor-alkall plant uses Cell Cote 682 or 505 to minimize absorption of mercury into cement floors,

The epoxy floors of the Fill Room of a switch manufacturer are dark green to allow for easy detection of liquid mercury. The epoxy coating is also used as a coping agalnst the walls in the room. This creates a 1-1nch lip where the floor meets the walls, thereby minimizing seepage of mercury between these two aurfaces.

One thermometer manufacturer totally recovered the floor of its manufacturIng area to reduce the absorption of mercury into the wood floors. The base of the main floor ( 11,000 square feet) was cleansed with several applicatrons of $\mathrm{HgX}^{\mathrm{R}}$, covered with 1/4-inch plywood, sealed with vinyl epoxy, and covered with vinyl tiles at a cost of $\$ 12,190$ (1980). The floor of the plant's mercury Fill Roon (440 square feet) was covered with several sheets of vinyl that were sealed together to form a single sheet. This was done at a cost of $\$ 1,762$ (1980).

A sumary of the "Contanment" controls studied is presented in Table $V-2$.

\section{Ventilated Enclosure}

Ventilated enclosures are used to contaln and remove mercury vapor and particulate generated at or in process equipment and machinery. A ventilated enclosure should combine process practicality with effective contaminant capture. Exhaust atr ducts should be opposite the access points of the enclosure to draw arr (and mercury) away from the worker's breathing zone. It is important to have an opening in the unit (such as a port, access point, plastic strip curtain, or small crack) so that the exhauster is able to draw air through the enclosure. If supply air is used in the enclosure in combination with the exhaust air, it must be at a lower flow rate and directed in line with the exhaust stream, otherwloe, the supply air will diaperse the contamı nants. 


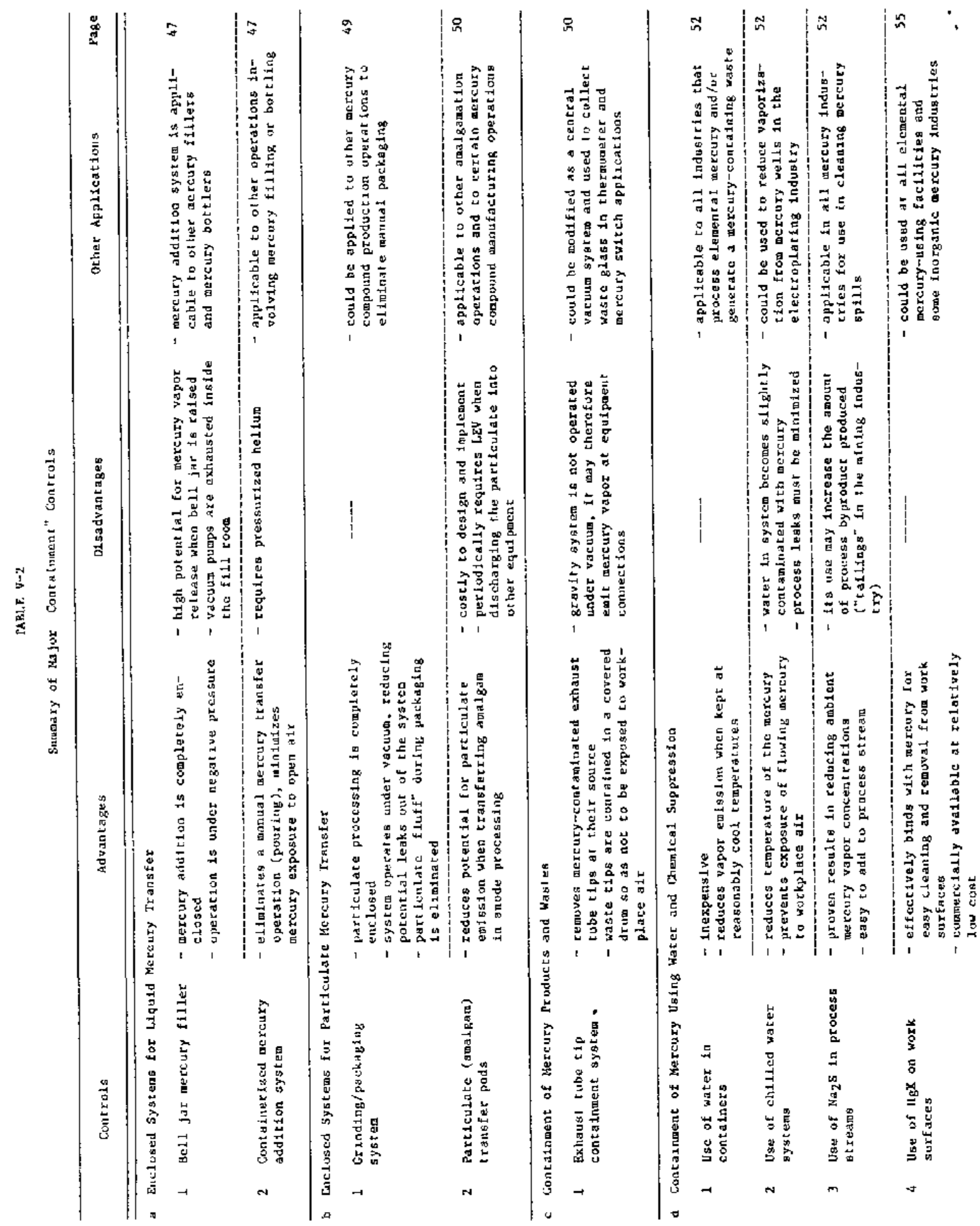




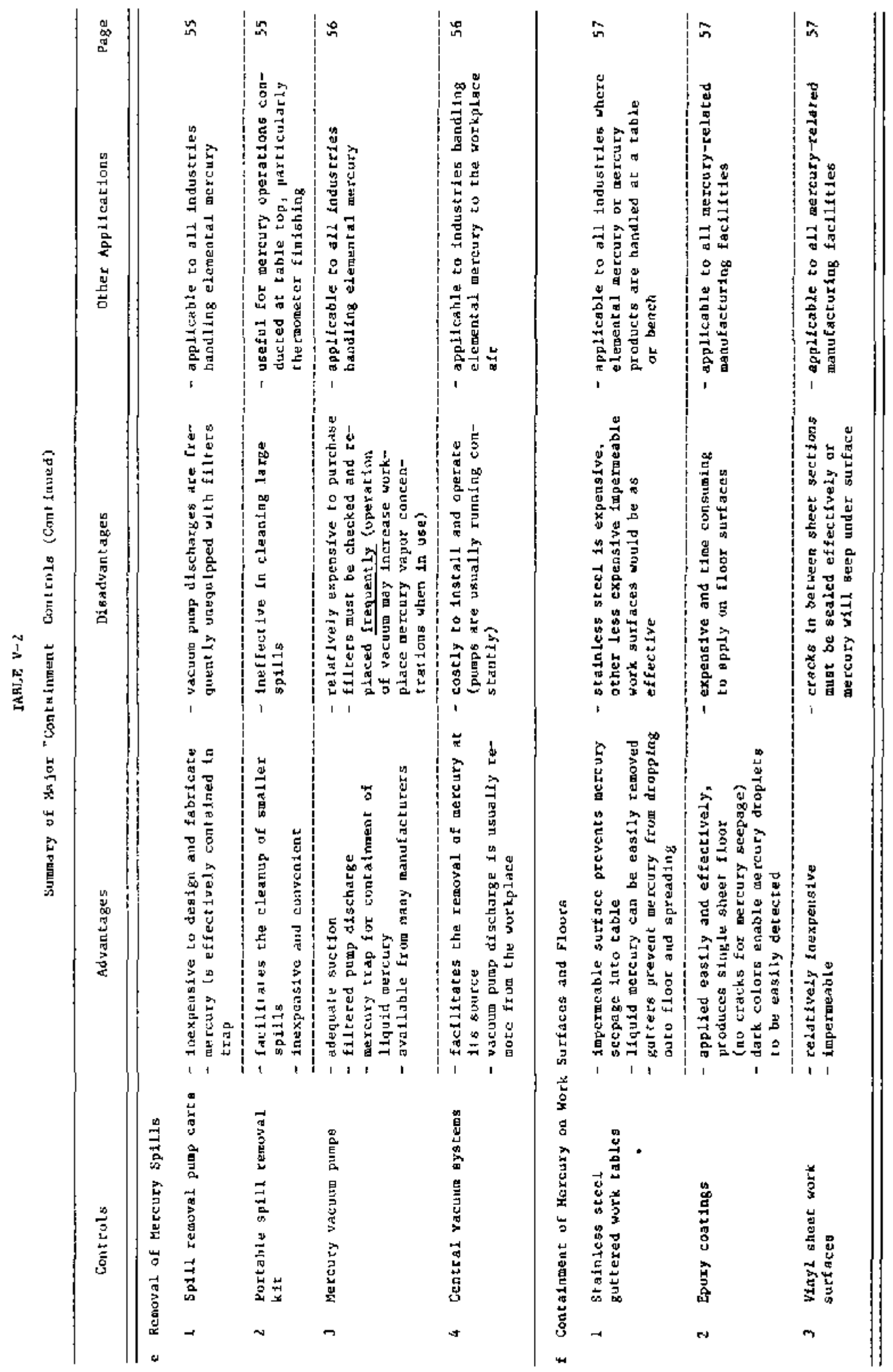


a. Ventilated Enclosure of Process Equipment

$\Lambda$ ventilated enclosure is used at the mill in a mercury mine to remove mercury vapor and particulate generated by a 6-foot-dlameter disc filter at the furnace feed. The enclosure is constructed of fiberglass and fiberglass caated wood. The exhaust duct is standard PVC piping. These materials are used instead of metal because of the corrosive sulfur dioxide gas present in the gas stream. The enclosure is exhausted by a 3,500-cfm fan lacated on the roof. This control is important because furnace operations occasionally fluctuate between negative and positive pressure, allowing hot mercury vapor to travel back through the feed screw conveyor and 1nto the fliter. This concept of controlling the release of mercury vapor at operations that may experfence pressure fluctuations can be applied to mercury stills, retorts, and reactors. The concentrate storage tank at the mill is also enclosed and ventilated to control mercury vapor. The tank is exhausted through PVC piping that leads to the same 3,500-cfm exhaust fan used for the filter hood.

Manufacturing processes that require the use of mercury as an electrical contact use ventllated enclosures for controlling vapor emissions from mercury pools. A sintering operation studled has cabinet-style ventilated enclosures over the mercury cups used in 1 ts process. The enclosures have a separate, vertically sliding door for each bottle. The doors are kept. cloged except when $a$ bar is loaded or unloaded from a bottle. Each set of vent1lated enclosures has 12 - by $12-1$ nch exhaust air ducts coming off both sides. The ducts combine into a 22- by 22-inch central duct that leads to a 600-cfin roof exhaust fan This system was designed and installed to draw air through the faces of the enclosure for each sintering unit and exhaust the arr along with the mercury vapor emitted from the cups. The mercury wells used in a copper piating operation are contained in ventilated enclosures that exhaust to a mercury vapor filter. Each well has a Plexiglas cover wath a flexible duct connected to a manifold. There are two manifolds, one for each set of drum plating units of the plant. Each manifold exhausts to a Calgon Vent-sorb filter (described in section on "Mercury Removal from Alrstreams" p. 83). The two fllters are connected to a common blower that draws the a1r through the entire system. The blowex is a DR 6 Roton blower rated at $100 \mathrm{cfm}$.

To reduce the potential for mercury vapor escaping from the fnlet and outlet boxes on the electralytic cells at a chlor-alkali plant, the boxes have been designed with ventilated enclosures. Each box has a steel cover over it with access doors for mercury addition and removal. This enclosure has an exhaust air takeoff that leads to an exhaust mantfold connected to the ather cells. The air is exhausted by a 1,500 $\mathrm{cfm}$ compressor located on one side of the ce1l room. The orlginal system was exhausted through a roof stack. Environmental concerns about emission of mercury vapor into the ambuent air prompted the company to install a Pura-SivR mercury removal system (described in section on "Mercury Removal from Afrstreams") similar to the one used to remove mercury from the hydrogen product stream. By removing mercury from the airstream, plant representatives feel that they have also Indirectly reduced mercury vapor levels in the workplace becauge the afr exhausted through the stack may have been contaminating the supply arr that entered the butlding. 
b. Ventilated Enclosure of Manufacturing Machinery

Ventilated enclosures can provide effectlve control for mercury emfsaion from manufacturing machincry. Manufacturers of mercury bucton cells use ventilated enclosures to reduce worker exposure to mercury parttculate in grinding, screentag, and pelletizing operations.

One button cell manufacturer encloses its presses, slant screens, and granulators in box-shaped (approximately 6 feet high) Plexiglas structures with three or four exhaust takeoffs (FIgure v-10). A 50-fpm minimum air velocity 19 alintained across the enclosures. Two baghouses are used to filter the particulate from the exhaust airstream. Plant management became concerned over increased worker exposure to particulate relating to the use of these enclosures. It was found that the worker access points in the enclosures were situated in positions that had high particulate concentrations. To solve this problem, they redeslgned the enclosures so that workers can make ad justments to the units from outside of the enclosure rather than from inside. The sections of the machinery that are now enclosed and ventilated require little or no worker access. The cost of these new enclosures is estimated to be $\$ 5,000$ per unit $(1981)$.

The same manufacturer stores its completed anodes and cathodes in ventllated enclogures on the cell assembly lines. Each enclosure has an exhaust alr takeoff leading to a baghouse.

Another button cell manufacturer uses Plexiglas exhaust structures to enclose its mixing, pelletizing, and consolidating machinery. The mixing of powters is conducted inside a ventilated glove box (Figure V-ll). The glove box enables a worker to handle contalners of powder and to aperate a mixer without rasking dermal contact with the mercurtc oxide powder. It also a1lows these operations to be performed inside a completely enclosed hood, minimizing the risk of workers breathing the powder. Enclosures around the machinery that frequently requires human access are equipped with "iris ports." An irfs port is a hole in the plexiglas that has a ring of rubber flaps covering it. When machine access is neceasary, the worker slips bis arm through the flaps, which become snug around his arm to allow minimal a1rflow out of the port. Iris ports also allow a small amount of afr to be drawn through the port. An iris port la shown in the center of the glove box in Figure $\mathrm{V}-11$.

One manufacturer of temperature-sensing elements has developed unique ventilated enclosures that are directly applicable only to that process, however, the principles of performance may be applied in the construction of enclosures for other industries. The mercury fill station at this facility is an enclosed workbench with a manifold designed to f111 12 capillary-bulb assemblies at one time. The station enclosure is a fixed, three-sided stainless steel hood (Figure V-12) with a cable lift, windowed door at the front (Figure V-13) that is kept closed during the fill process. Alr is exhausted through a 6 -inch duct on the top of the unit. Outside anr is supplied to the enclosure through two 4-inch flexible ducts located adjacent to the base of the door. When the door is in the closed position, a condult (built into the door) equipped with spectally positioned distribution baffles is used to provide a unfform airflow across the face of the station. A stainless steel, sloped tray containing 3 inches of water is mounted below 


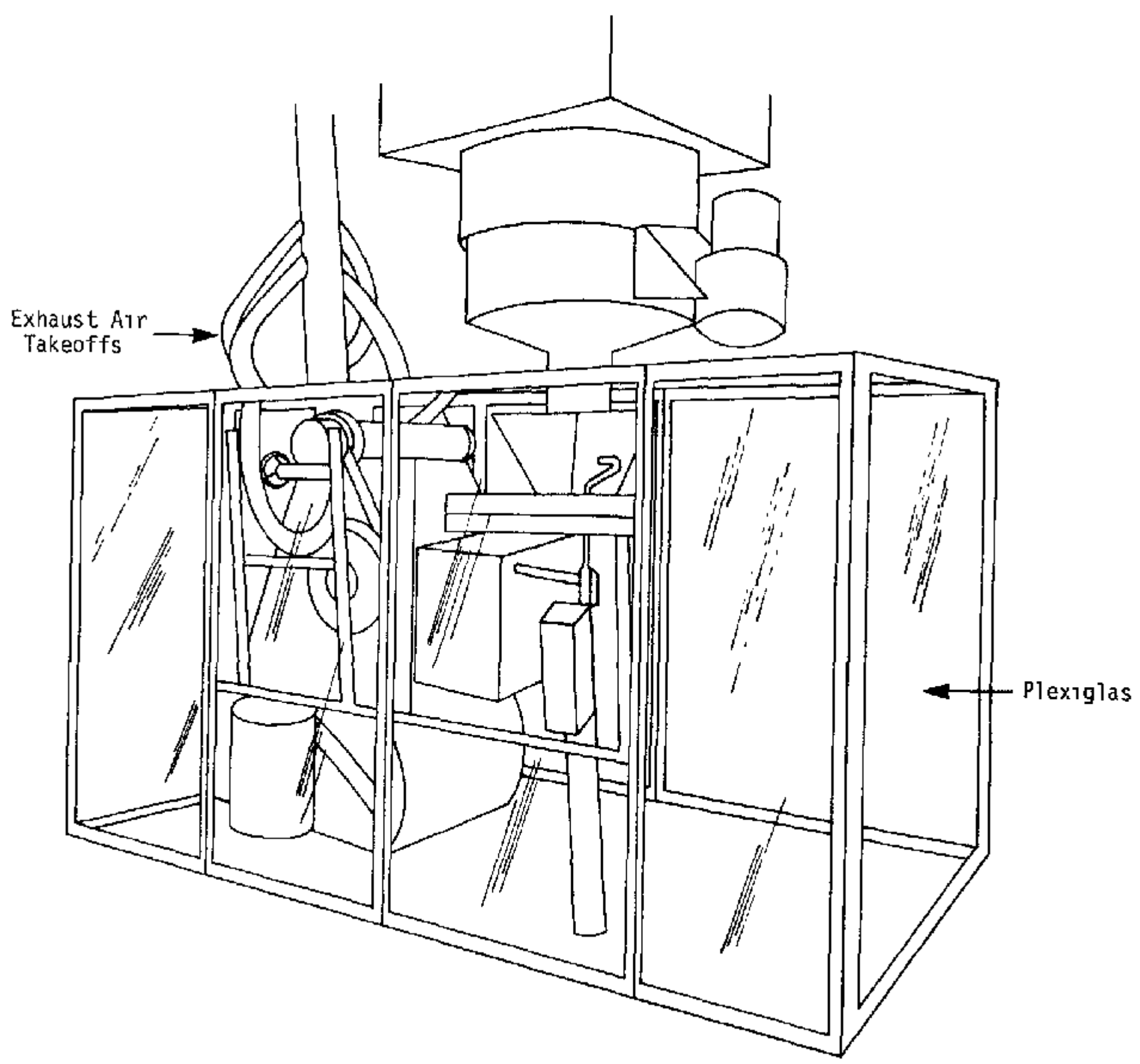

Figure V-10. Plexiglas Mach1ne Enclosure. 


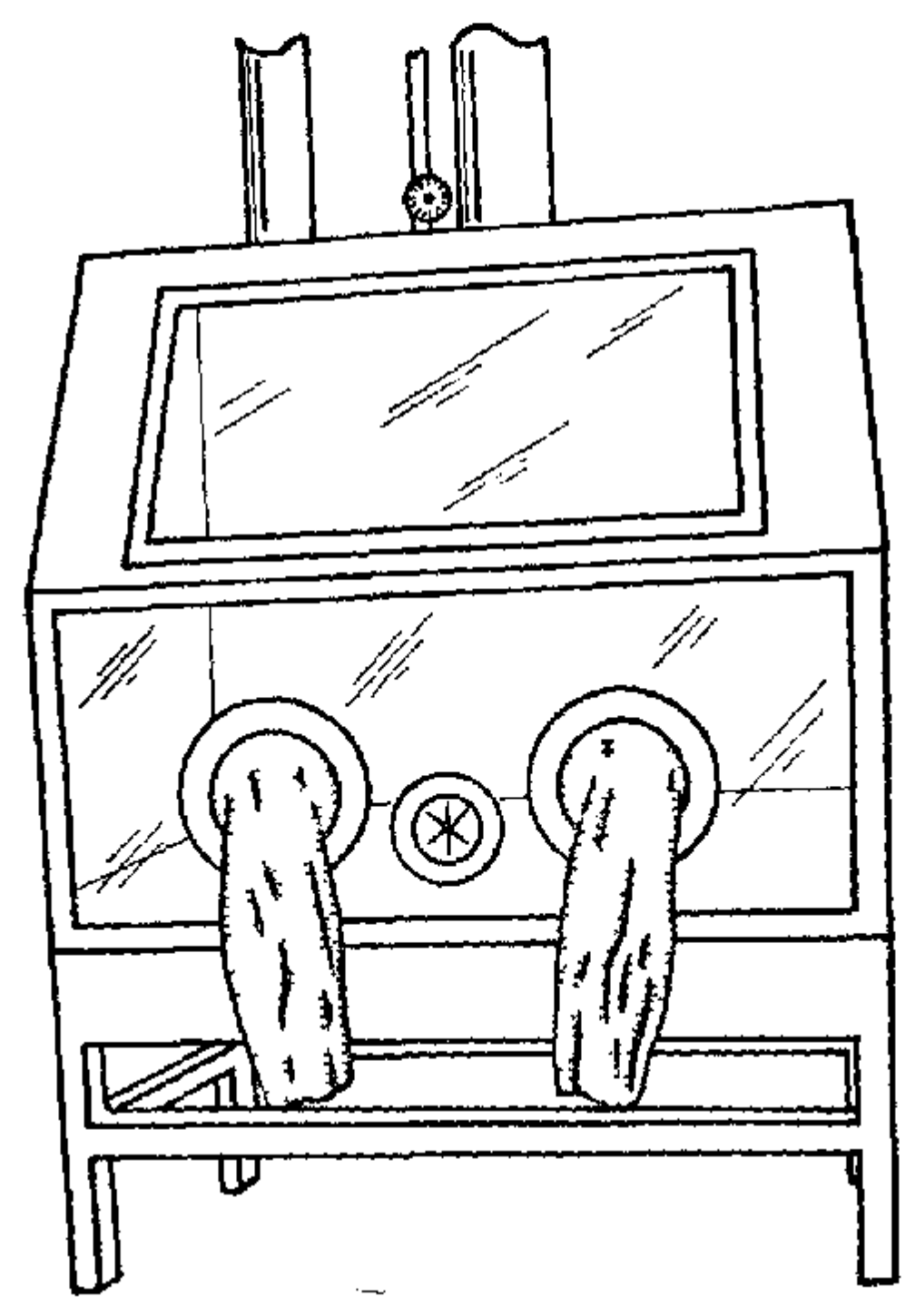

F1gure V-1L. Glove Box. 


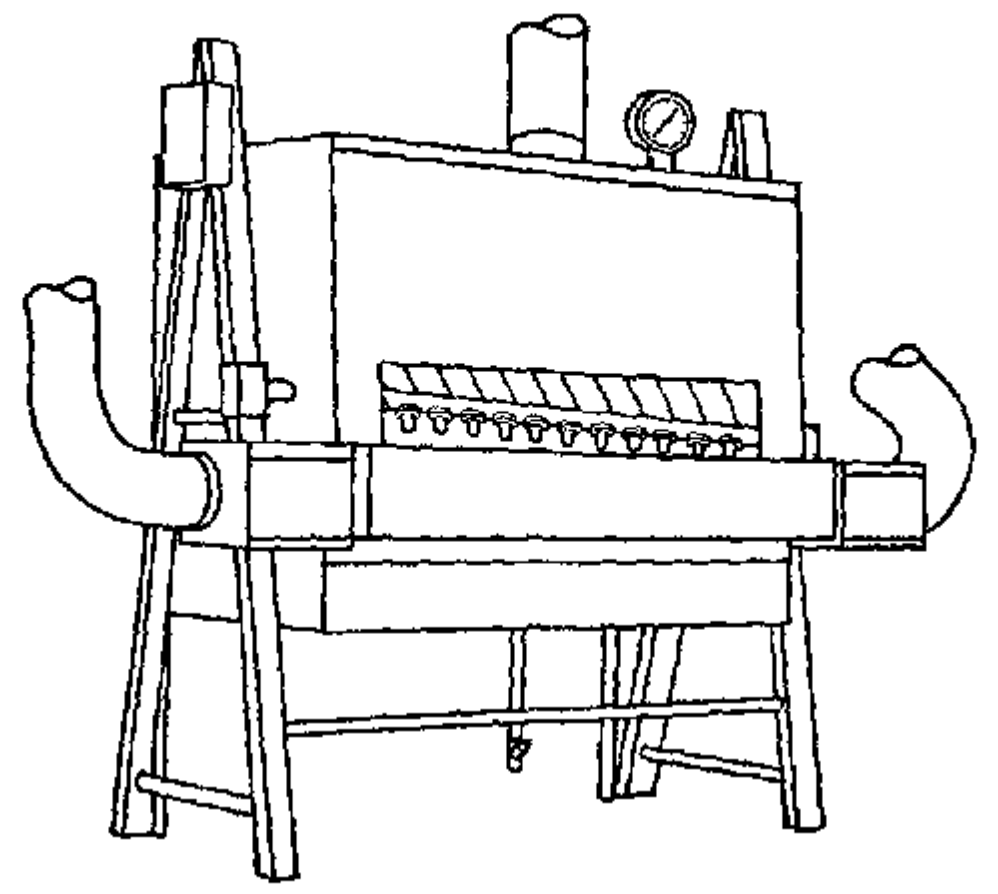

Figure V-12, Mercury Fill station Hood.

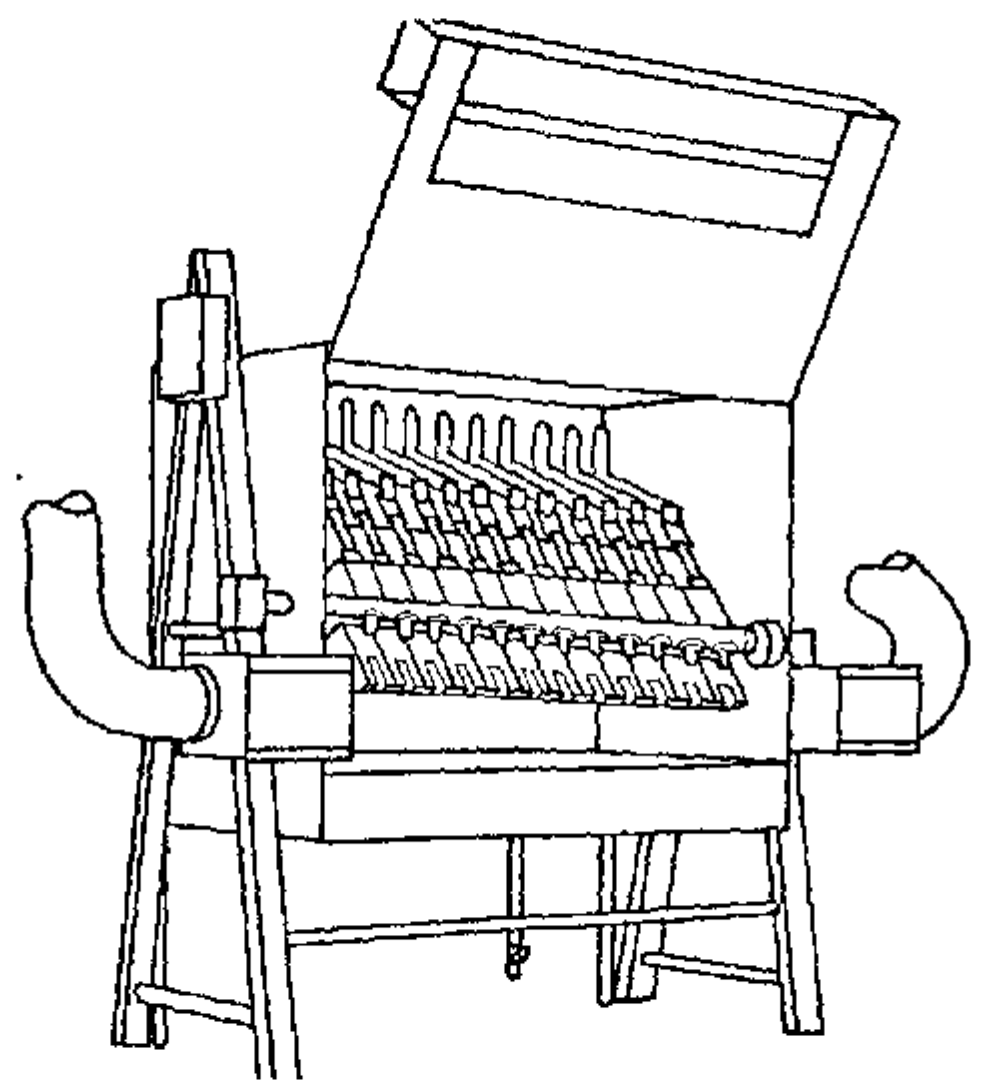

Figure V-13. Mercury Pill Station With Door Opened Showing the Mantfold. 
the manifold to hold mercury droplets that may leak out during the filling process. The water reduces mercury vapor emitted from the droplets. Mercury is perlodically drained from this tray through a trap in the bottom.

A Bummary of the "Ventilated Enclosure" controls studied is presented in Tabie $\mathrm{V}-3$.

\section{Local Exhaust Ventilation}

Local exhaust ventilation is used to control uncontained emission sources so that mercury vapor and particulate are removed from the source quickly and effectively. The two most important requirements for locdl exhaust ventilation systems are. (1) the exhaust atrflow is away from the worker's breathing zone, and (2) the physical design and airflow of the ventilator provide effective capture and removal of the contaninant. The exhaust airflow from the lacal exhaust ventilation system should be to the exterior of the buildlng or preferably to a mercury vapor/particulate filter systera. Different. types of local exhaust ventilation syatems employed for various mercury operations are presented in this section.

a. Work Station Exhaust Hoods

Industries with mercury-filling operations usually rely heavily on local exhaust ventilation for controlling mercury vapor. This is particularly true of operations performed at workbenches. An exhaust hood used at a calibration station at a thermometer manufacturing facility is a tbree-sided, stanless steel booth with two $10-1 n c h-d t a m e t e r$ wall exhaust fans mounted inside. The booth encloses a workbench containing oil and water baths for calibrating the mercury-filled glass tubes. The booth is 80 inches wide by 48 inches high by 22 inches deep. The face of the unit 18 slanted and the velocity measured across it was $21 \mathrm{fpm}$. Total airflow through the unit was calculated to be $330 \mathrm{cfm}$. The cost of this hood was $\$ 1,800$ (1977). This three-sided exhaust hood is typical of many lacal exhaust ventilation systems at mercury work stations except that the face velocity was relatively low

Some exhaust hoods have additzonal local exhaust ventilation aystems motnted inside. An example of this type of hood is found at a work station in a mercury bottle flling operation The station, consisting of two bottle fillers, is enclosed by a three-sided exhaust hood. The roof exhaust fan for the work station is a $1,400-c f m$ (design) Greenbeck Model CBE1884 situated outside of the buflding. The fan draws alr through a 3-by 70-inch slot at the back of the hood at bench level, and through two gooseneck local exhaugt hoods (6- by 6-finch openings) located 1mediately above each bottle filler. There are two Mylar sheets on the front of the hood that, when drawn down across the face of the hood, increase exhaust afr veloctry through the remaining open hood space (Figure V-14) The atr velocity across the face of the three-sided exhaust hood was measured to be approximately $100 \mathrm{fpm}$. Measurements of the Individual local exhausters inside the hood yielded the following results

- local exhaust over each bottle filler - approximately 600 fpm (150 cfm each)

a siot hood - approximately $550 \mathrm{fpm}(800 \mathrm{cfm})$. 


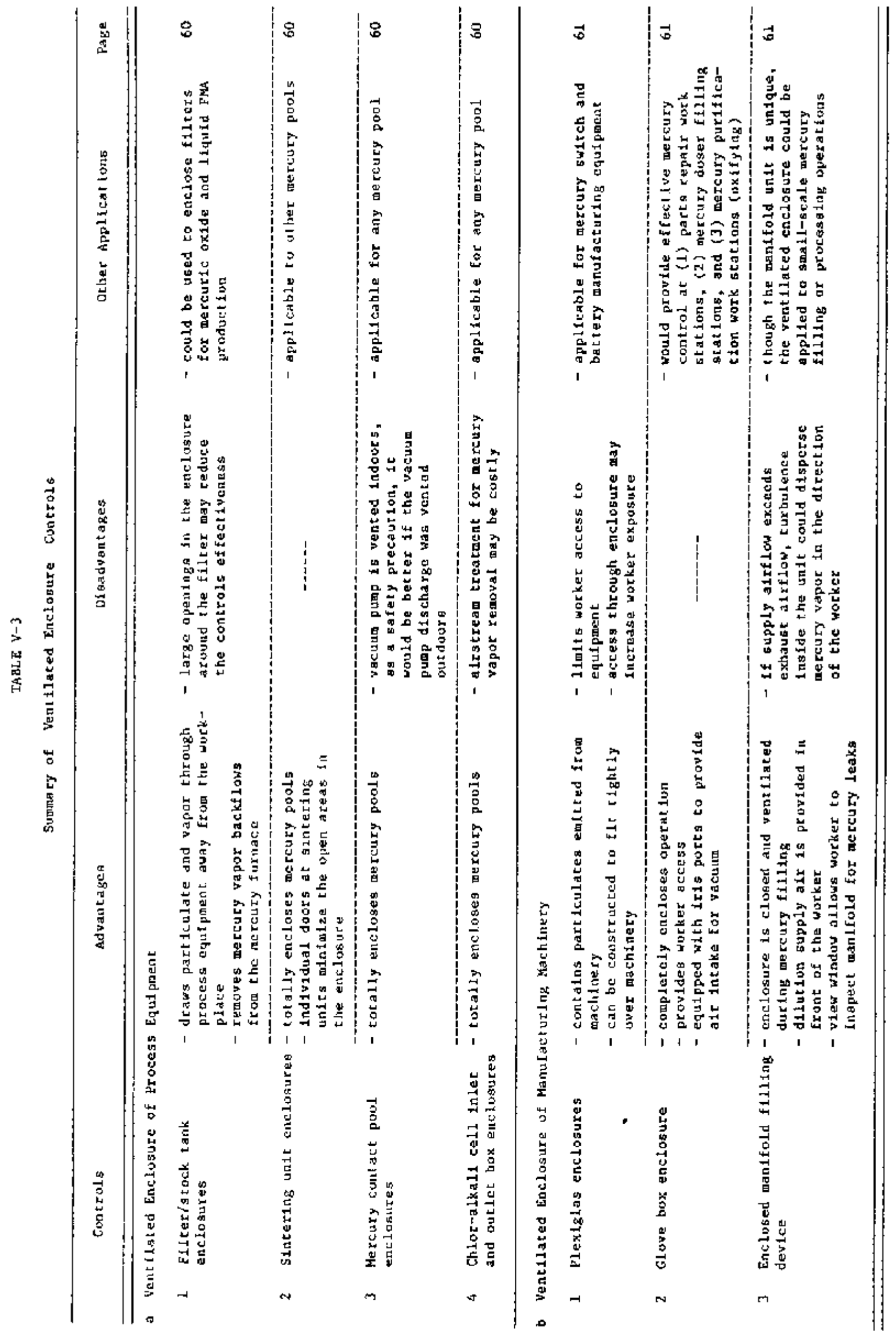




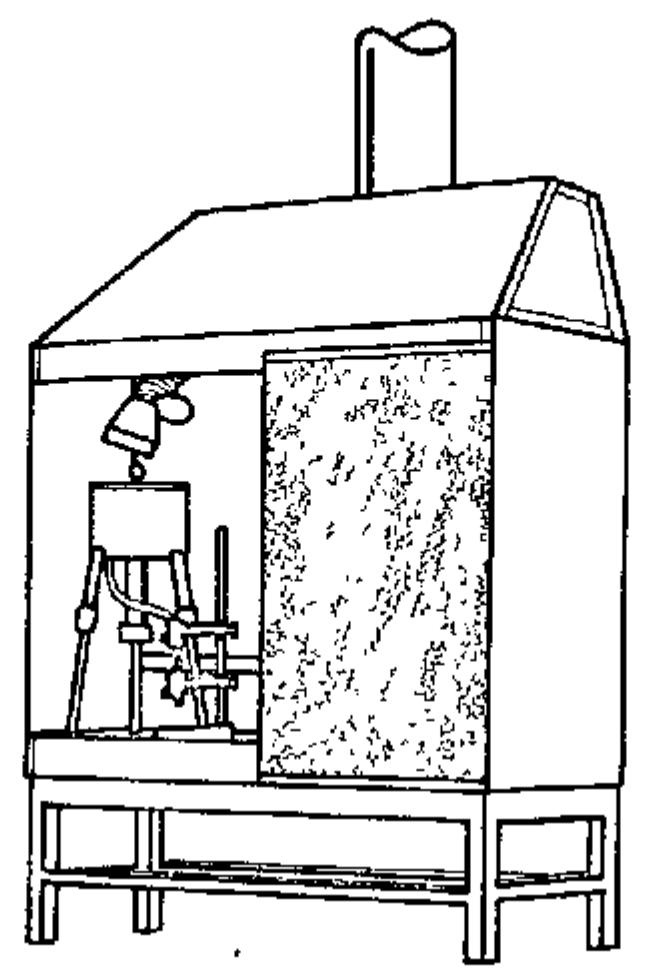

Figure V-14. Mylar Sheet Across the Face of the Exhaust Hood.

Fluorescent lamp manufacturers use workbenches with exhaust hoods for filing mercury dosers (for the exhaust machines), working on mercury-contaminated parts, and purifying mercury through oxification and filtration. The threeslded hood used at the doser flliing station at one plant has a vertically sliding Plextglas door. The door is lowered as tuch as possible while still allowing enough room for the workers' hands to reach the equipent inside the hood. This tncreases the air velocity across the face of the hood. othex features at the work gtation include (1) a stainless steel work surface with a lipped edge to prevent mercury from ralling off the bench, (2) a grated section covering a water-filled sink to contain spilled mercury droplets and suppress vaporization, and (3) an air supply vent at the outside of the hood to provide dilution air for the worker.

Smaller operations performed on mercury products at workbenches are frequently controlled through the use of smaller exhaust hoods. Examples of these include slot hoods, canopy hoods, and backdraft rectangular hoods. These controls are typically situated immediately adjacent to the mercury use area.

One thermometer manufacturer uses a workbench local exhaust ventilation system conststing of five bench-mounted, tapered, rectanguiar exhaust hoods (4by 10-inch horizontal intake). Each hood 1s mounted approximately 9 inches off the surface of the workbench. The untts are exhausted by a 20-1nchdlameter wall fan. Measured afrflow through each hood was approximately 50 afm (180 fpm). Smoke tuhe test1ng showed that the capture zone on these units extended approxtmately 4 inches, not adequate for effective removal of mercury vapor from the workbench. The cost of this local exhaust ventilation system was $\$ 1,503$ (1977). 
b. Equipment Exhausters

Local exhaust vent1lation is frequentiy employed to remove mercury vapor and or particulate generated at manufacturing equipment. This type of local exhaust ventilation systen is usually custon designed to fit specific mercury handling machines and devices. One mercury switch manufacturer uses a specially designed circular slot exhaust hood to draw alr over the mercurycontalnting metal cans riding ta cartier cups on the filling and welding machine. The circle 1 s 40 inches in diameter with a l-inch-hfgh slot around the perimeter. A 16-1nch circular exhaust duct extends from the center of the curcular slot exhaust to an exhaust network at celling level. The average velocity through the slot hood was found to be 1,500 fpm, which indicates an exhaust airflow of $1,300 \mathrm{cfm}$. Contaminant capture distance measured using a smoke tube shows effective capture across all of the carrler cups on the welding machine.

One mercury switch manufacturer uses flat, circular exhaust hoods directly over its filling machines to remove mercury vapor. In addition to this, air is extausted from the periphery of the filling machine using curved slot hoods. A small, horizontally faced local exhaust ventilation systen is sttuated directly in front of the fill station on the machine. Some machines have plastic strip curtains suapended frot the circular exhaust hoods. The strip curtain helps to contain the mercury vapor generated, and it increases the Eace velocity across the open areas of the curtain where the workers access the machinery. The plant management has found that this control reduces mercury vapor concentrations, and has plans to install plastic curtains on all of the circuiar exhaust hoods.

Fluorescent lamp manufacturers use exhaust hoods over their mercury filling machinery. These hoods remove heat and mercury vapor generated in the procesa. One manufacturer uses an exhaust hood that covers the top and part of the sides of the machinery. The exhaust aur takeoffs from the hood lead to a 7,500 $\mathrm{mfm}$ exhaust fan. Another lamp manufacturer has attempted to remove heat and mercury vapor from the lamp manufacturing equipment by installing commercially available Fyrepe ${ }^{R}$ shrouds over the machinery in one of its production dreas (FIgure $\mathrm{V}-15$ ). The shrouds are similar to large exhaust ducts leading from above the machines to certain roof exhaust fans. They create a chimey effect that directs the exhaust alrflow from the points of mercury vapor and heat generation to the roof exhaust.

Local exhaust ventilation systems are employed at various points in chemfcal manufacturing processes. One manufacturer of mercuric and mercurous chloride uses an exhaust hood that is stituated over the door of the mercuric/mercurous chlorlde reactor to remove mercury vapor released when the door is opened. The face of the hood is approximately 30 inches wide by 6 inches deep. It leads to a roof exhaust fan and a caustic scrubber for chlorine gas and mercury vapor removal.

The PLA drying, granding, and packaging operation at one plant has a loca1 exhaust ventilation system consisting of three 12-inch-diameter exhaust air takeoffs. One takeoff is adjacent to the station where the PMA 19 loaded into drums after drytng. The second takeoff is an exhaust hood mounted on the side of the loading hopper for the grinder. The thira takeof is a semicircular slot hood mounted at the edge of the drum Ioading stand for PMA coming of $f$ the grinder (FIgure V-16). The ducts from these takeoffs connect 


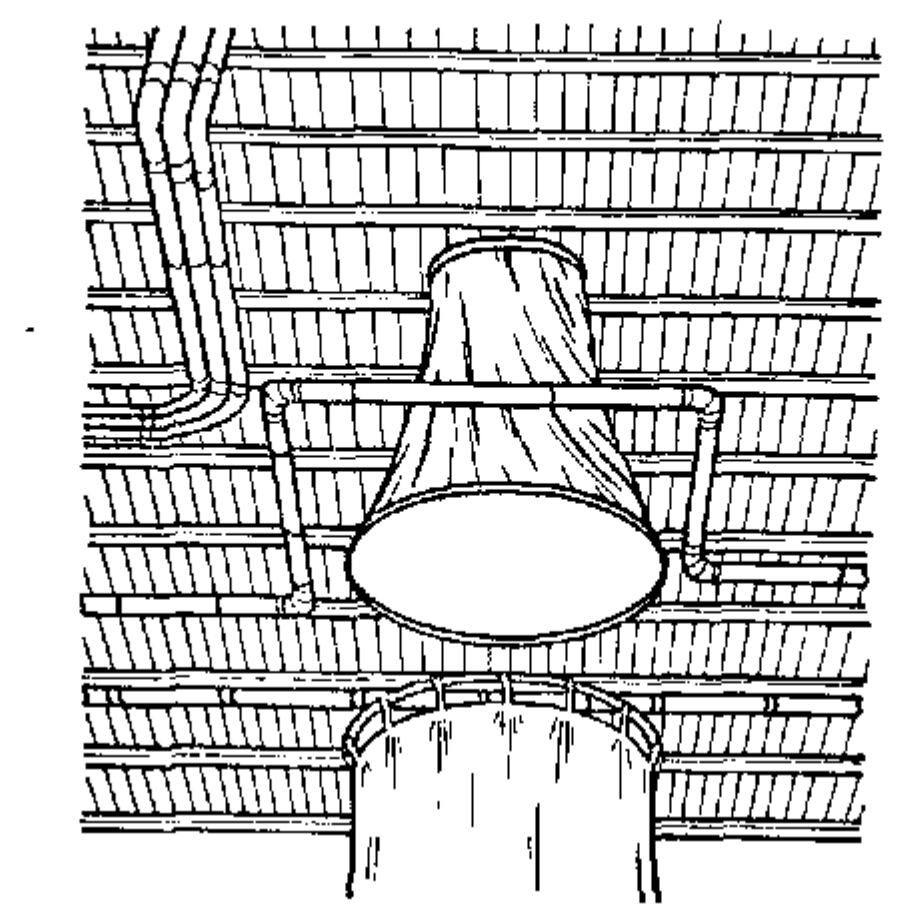

Figure V-15. Shroud Over Exhaust Machfne.

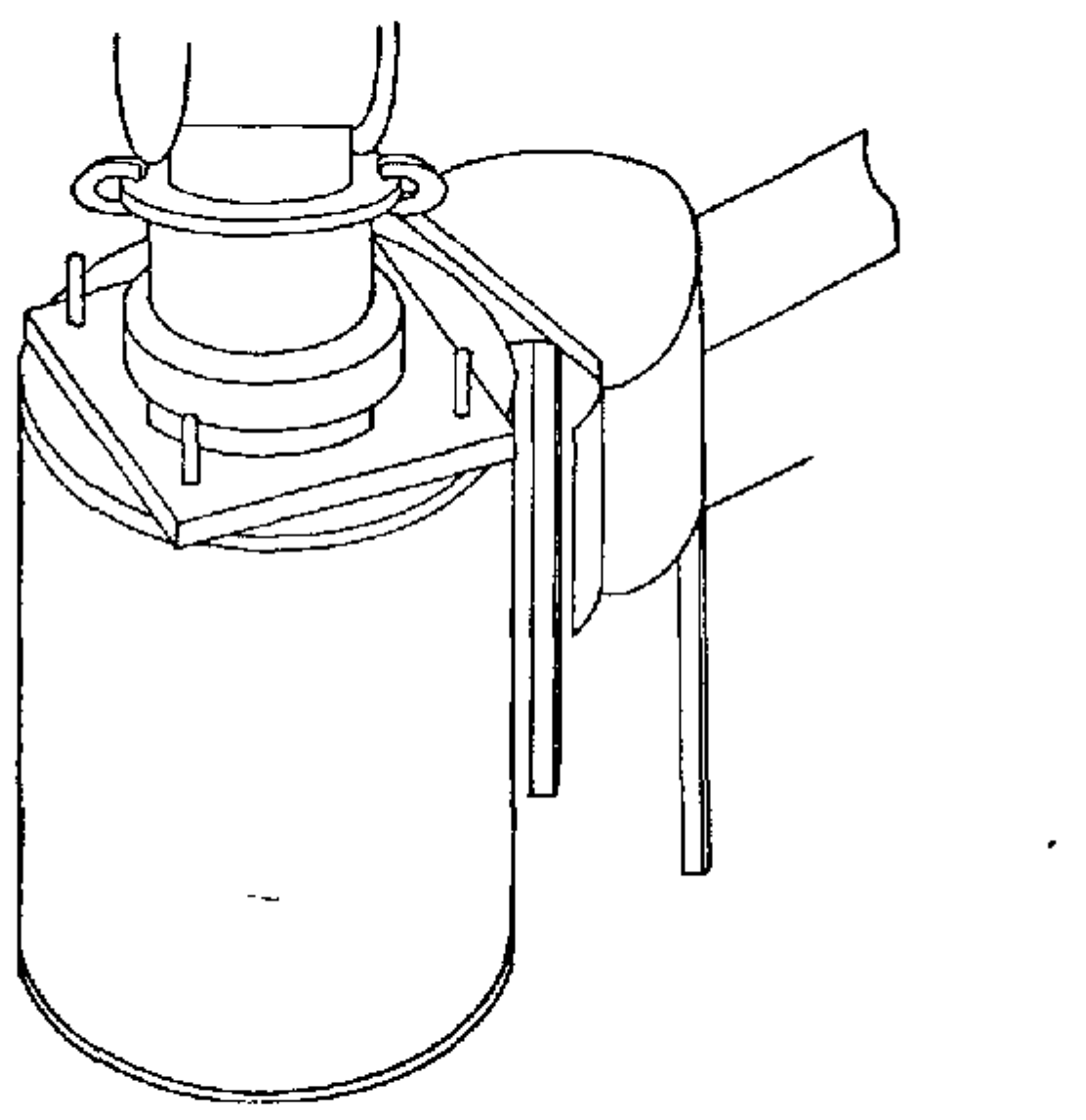

F1gure V-16. Exhaust A1r Takeoff at Drum Loading Stand. 
to a blower that exhauss into a large conical-shaped bag (Figure V-17) mounted in an upper corner of the bullding. The bag collects the powder dispersed into the air at the three locations previously mentioned.

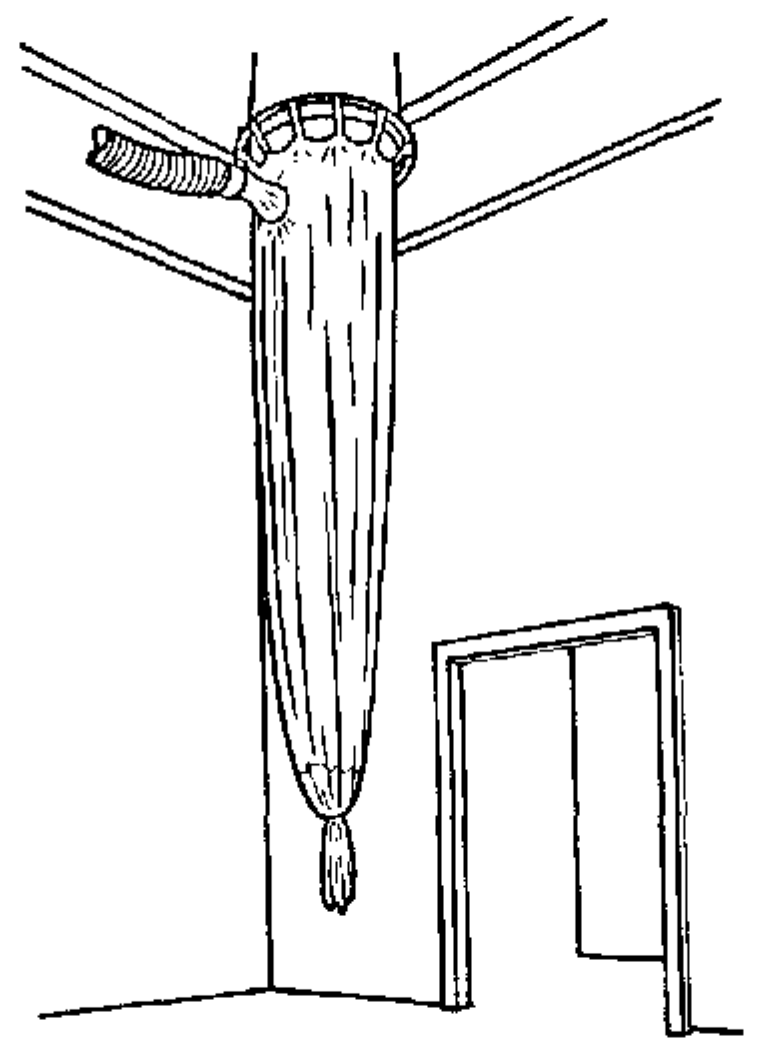

Figure V-17. Filter Bag for Removing PMA frow Exhaust Air.

Another PMA manufacturer uses a specially designed, ventilated charger hood for the addition of mercuric oxide to reactor vessels. This control reduces worker exposure to mercury particulate generated when bags of the oxide are opened and emptied into the manhole on the reactor. The charger hood (F1gure $\mathrm{V}-18$ ) $1 \mathrm{~s}$ a stainless steel structure with openings for the manhole, an exhaust duct, and a waste disposal bag. The hood 18 used in the followIng manner:

o The reactor manhole is opened, vacuun is applied to the reactor, and the hood is put in place over the opening.

- A flexible exhaust duct is connected to an opening on the top of the hood. 

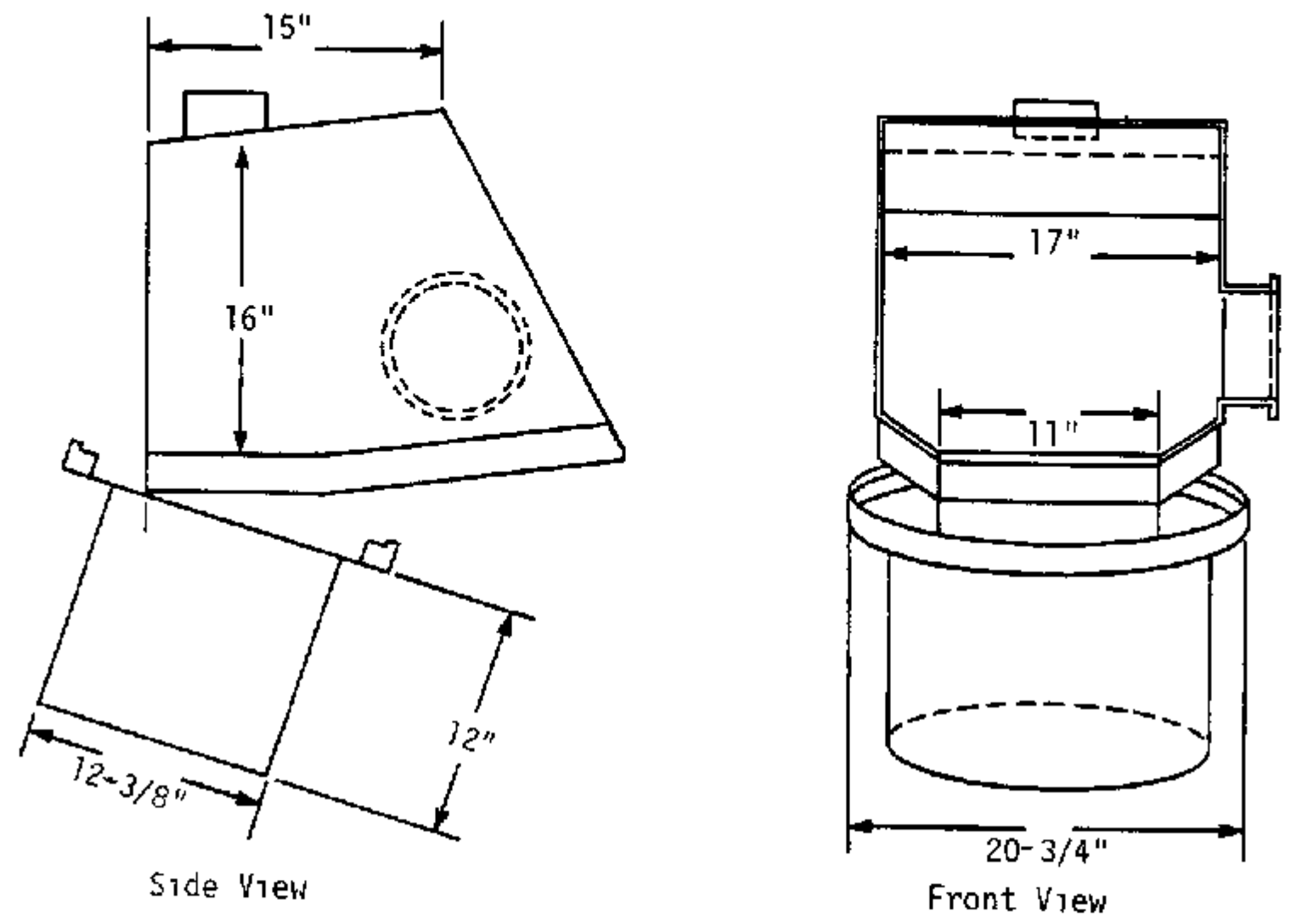

F1gure Vu18. Mercurac Oxide Charger Hood Design. Reference: Plant Drawing from stte visit

- A plastlc refuse bag is connected to an opening on the side of the hood.

- The worker opens the plastic 11ner of the 50-pound mercuric oxide contalner and emptles the bag into the manhole.

o The empty bag Is put into the refuse bag on the side of the hood, The refuse bag is sealed and disposed of in a drun for hazardous waste.

- The exhaust duct is disconnected, the hood is removed from the opening, the reactor is vented, and the manhole is cloged.

The exhaust hood is movable so that it can be used at any reactor being charged with mercurfc oxide. The exhaust duct leads to a roof exhaust fan that draws approxinately $430 \mathrm{cfm}$ (measured). A HEPA filter is used to remove the particulate mercury from the exhaust alrstream.

Dilute PMA powder mlxed in a V-blender at the same facility is loaded in drums under a specially designed exhaust ventilation unit. The unit consists of a plastic dust hood (Figure V-19) that is hydraulically lowered over the empty drum before filling. Three flexible exhaust air ducts are attached to the hood. Before loading the drum, a flexible chute is connected from the hood to the blender discharge. This helps to enclose the fill syatem and reduces powder dispersion. The exhaust air ducts lead to a 16-bag 
Mikcro Pul 16s-8-30 baghouse that uses a pneumatically controlled knocker to shake filtered particles into a waste drua. Watte 1a recycled through the blending process.
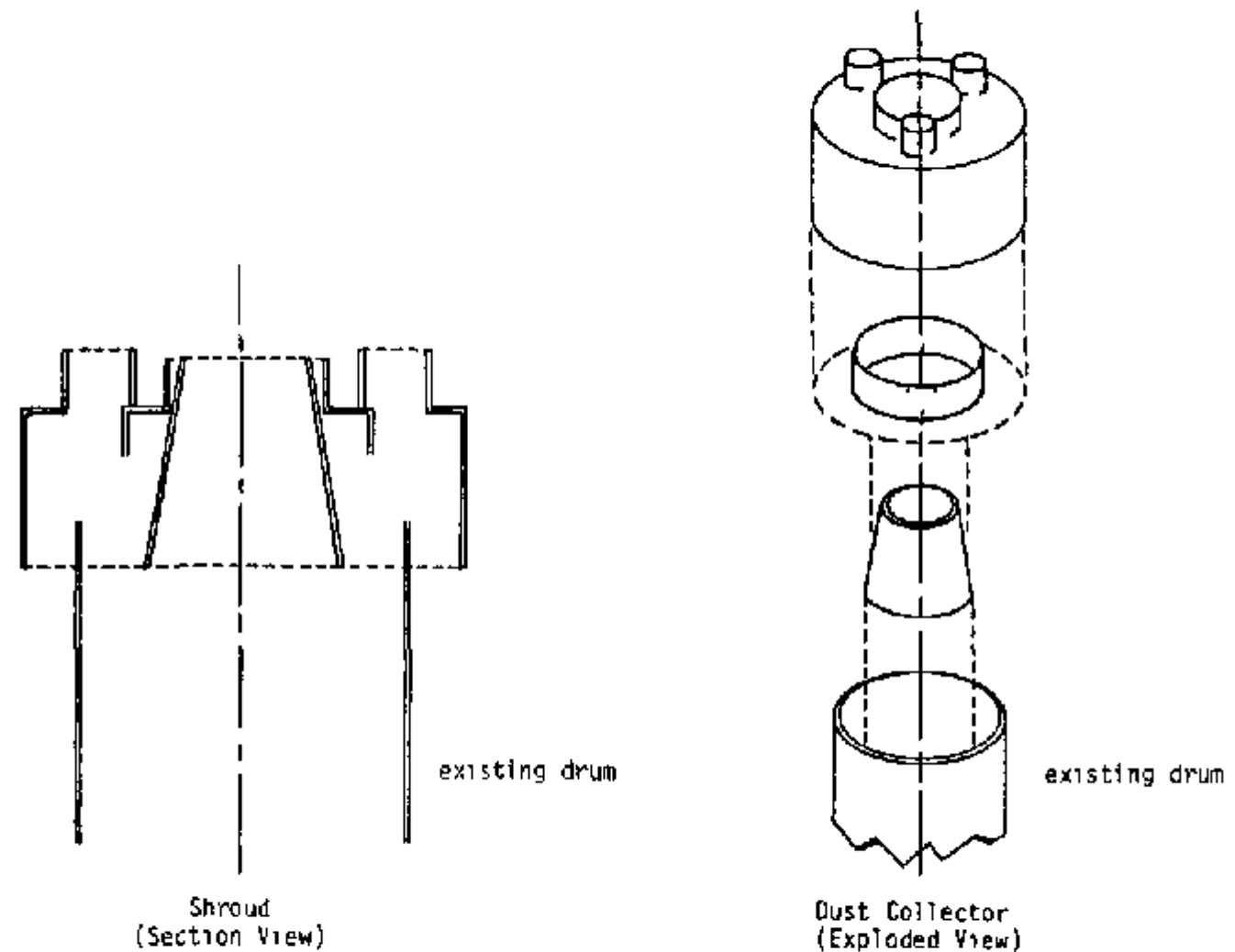

Figure $\mathrm{V}-19$. Schematic Drawing of Drum Loading Hood.

Reference. Plant drawing from site visited.

A f11ter press used at the plant in the purffication of a liquid PMA product has a 2.5- by 5-foot exhaust hood that is lowered over the press while it is operating. The hood has a large baffle inside that creates a 1-inch slot around the periphery of the hood to increase exhaust alr veloctty. A 12-inch exhaust duct connects the hood to the same exhaust fan used for the mercuric oxide charger hood. The two cantrols can be isolated so that approximately $530 \mathrm{cfm}$ can be drawn at e1ther hood.

A summary of the "Local Exhaust Ventilation" controls studied is presented in Table V-4.

\section{Temperature Control}

The vapor pressure of mercury gignfficantly affects the workplace mercury vapor concentration. The temperature of the mercury and/or the workplace air In any mercury-using facllity deterwines the degree of vaporization of mercury. 


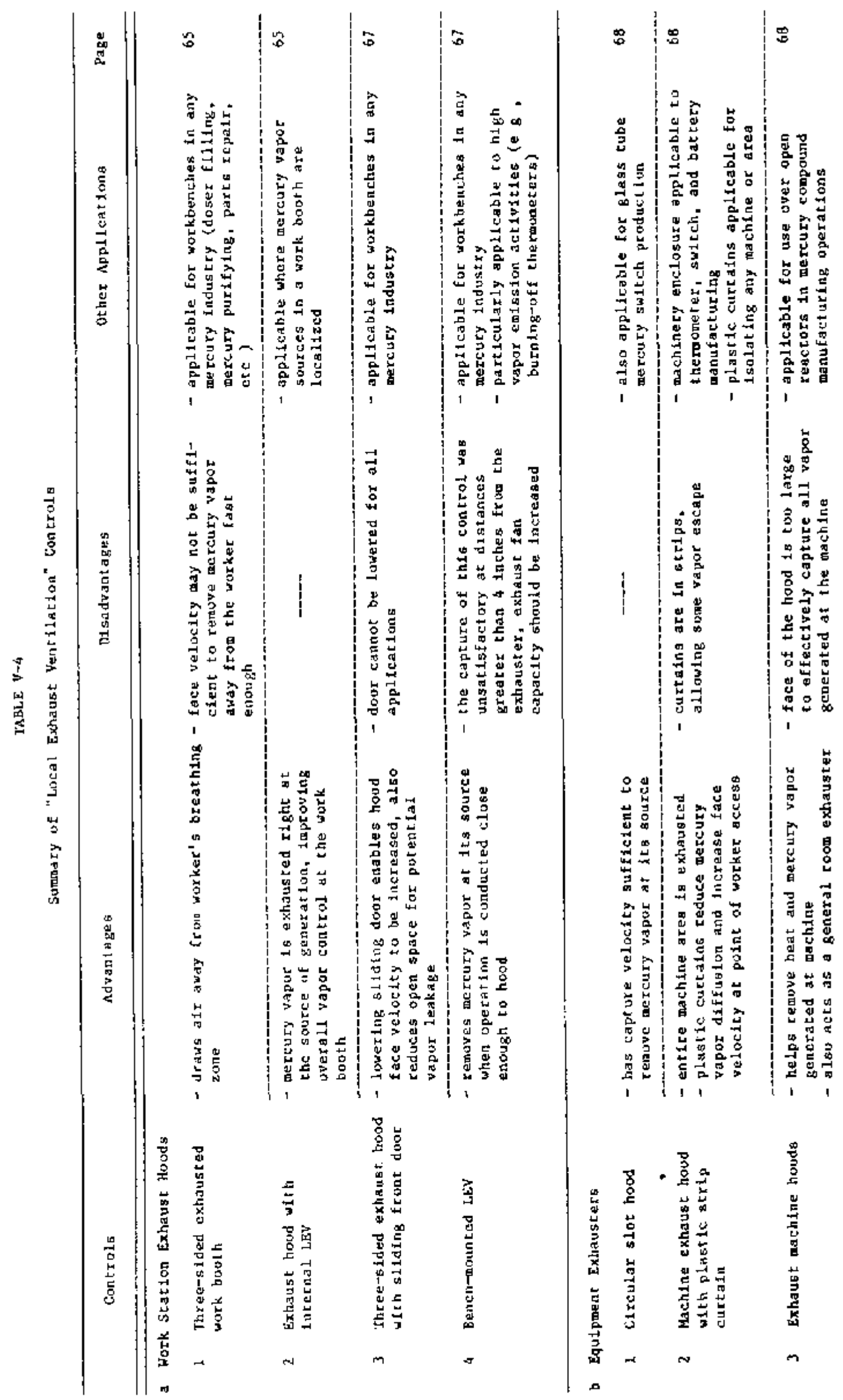




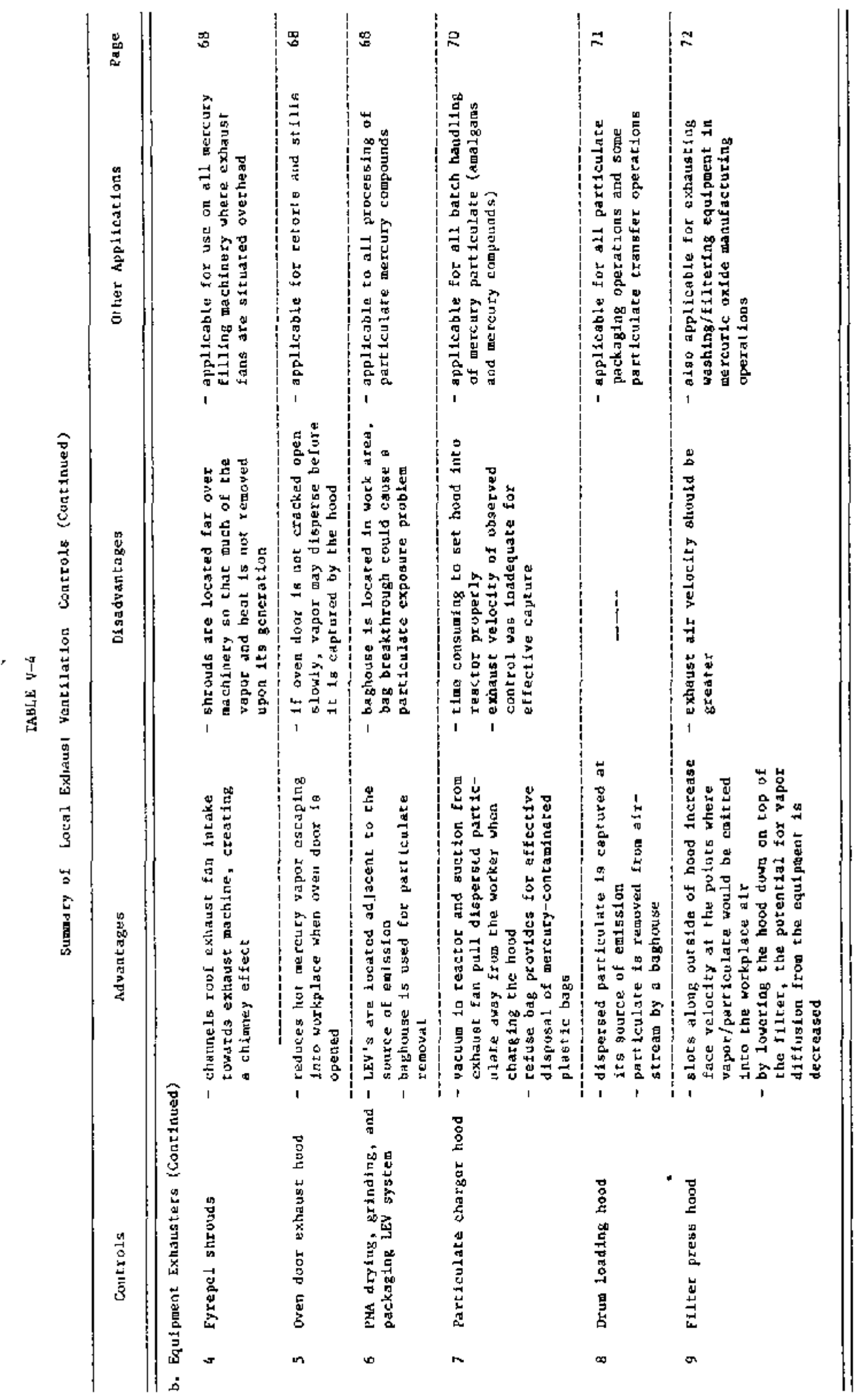


Many facilities handlug merrury exposed to the anbtent atr malntatn a workplace temperature of approximately $20 \mathrm{C}(68 \mathrm{~F})$. Table $V-5$ illustrates how a devidion of a few degrees above 20 c results 1 a a stgnificant increase in the vapor pressure of mercury. The table shows that by raising the ambient aif temperdture frot $18 \mathrm{C}(64.4 \mathrm{~F})$ to $26 \mathrm{C}(78.8 \mathrm{~F})$, the vapor pressure of mercury us doubled. It can also be seen that a temperature increase from $24 \mathrm{C}$ to $26 \mathrm{C}$ results in almost twice the vapor pressure increase as a temperature increase from $16 \mathrm{C}$ to $18 \mathrm{c}$. Lowerting the temperature a few degrees in an environment where a large amount of mercury is used may make the difference between arhleving or exceeding the OSHA PEL.

TABLE $V-5$

Temperature Effect on Mercury Vapor Pressure

\begin{tabular}{cccc} 
Temp (C) & Temp (F) & $\begin{array}{c}\text { Saruration Conc } \\
\text { (mg/M) }\end{array}$ & $\begin{array}{l}\text { Vapor pressure of } \mathrm{Hg} \\
\left(1 \mathrm{M} 0^{-6} \mathrm{~mm}\right)\end{array}$ \\
\hline 16 & 60.8 & 9.40 & 846 \\
18 & 64.4 & 11.15 & 1009 \\
20 & 68.0 & 13.18 & 1201 \\
22 & 71.6 & 15.54 & 1426 \\
24 & 75.2 & 18.31 & 1691 \\
26 & 78.8 & 21.53 & 2000 \\
28 & 82.4 & 25.20 & 2359 \\
30 & 86.0 & 29.49 & 2777 \\
\hline
\end{tabular}

Mercury swith manufaciurers rely heavily on temperature to control mercury vaporization. In one plant surveyed, mathagement plases a high prtority on malntalning temperatures between 18 and $20 \mathrm{C}(64.4$ and $68 \mathrm{~F})$ at all times $\mathrm{in}$ the mercury Fill Room. There are four rhermometers in the room, and if the temperature of any one of them $\mathrm{ts}$ found to exceed $21 \mathrm{C}(69.8 \mathrm{~F})$, the operation is shut down and personnel are evaruated. Alr in the room is maintalned at this temperature using a General Electric aur-conditioner incorporated into the air handling unit. letmperature is set and monitored along with humbity on a master control panel located in the mercury Fill Room. Plant. representatives feel that temperature cuntrol ts the most effective control used at their plant for the prevention of worker exposure to mercury.

One electroplatting plant studied uses temperature control to reduce the vapor generated from the sercury contact wells. The wells were once a major source of mercury vapor contamination because the temperature of mercury in the 
wells could be as high as $82 \mathrm{C}(179.6 \mathrm{~F})$ depending on the equipment and operating conditions. The normal operating range is 26 to $82 \mathrm{C}$ (78.8 to $180 \mathrm{~F})$. Plant efforts were focused on reducing these temperatures by cooling the wells with chilled water. All new wells purchased were constructed with stainless steel water jackets on three sides. Older wells were reworked to accommodate a cooling aystem by drilling holes through the we11 bodles to act as channels for the chilled water.

The cooling system consists of a water hold tank, two punps operating in paralle1, a chiller bundle, and a closed loop pipe network that feeds each mercury well and returns the water through a manlfold back to the hold tank. The cost of the cooling systen was approximately $\$ 18,000$ in 1980 . The system provides a flow of chilled water $(4.4-10 \mathrm{c})(39.9-50 \mathrm{~F})$ that maintains mercury temperatures between 15 and $26 \mathrm{C}(59$ and $78.8 \mathrm{~F})$. Controllang the temperature of mercury to an average of $21 \mathrm{C}(69.8 \mathrm{~F}$ ) rather than at 26-82 C (78.8-180 F) (average $130 \mathrm{~F}$ ) can reduce the vapor pressure by a factor of 13 . This reduces the mercury vapor concentrations, due to vaporization at the wells, to levels that can be controlled using standard exhaust ventilation procedures. A c1ty water header is tied into the system to be used in the event the chiller is inoperative.

A summary of "Temperature" controls gtudied $1 \mathrm{~g}$ presented in Table V 6 .

\section{Dilution Ventilation}

At the plants surveyed, dilution ventilation was the most common engineering control uged to reduce workplace mercury vapor and particulate concentrations. Axr must be moved through the workplace at a rate sufficient to prevent the bulldup of hazardous concentrations of mercury. At the same time, the airflow must be well directed to provide consiatent ventilation and min$f_{\text {ral }}$ dead areas (where little air movement occurs). Unidirectional flow (from one wall to another or from celling to floor) helps to achieve this. older manufacturing facilitles frequently have several add-on ventilation systems installed over a period of time, making it difficult to provide unidirectional flow. These systems often require greater ventilation capactity than unidirectional systems to be effective in removing mercury vapor or particulate from the workplace.

Supplied dilution air at any plant using mercury is ugually conditioned for three reasons. (1) worker confort, (2) process requirements, and (3) mlnimization of mercury vapor concentrations. Conditloning supply air typlcally involves high operating costs, a point to be gertously considered when evaluating the use of dilution ventilation as a mercury control. For this reason, tany facilities employ wholly or partially recirculating atr systems with fllters to remove mercury vapor and particulate from the workplace. Although filter cost and maintenance are higher with recirculating systems, the overall operating costs are usually lower.

A selection of dilution ventilation systems is presented in this section to provide a general review of ventilation arrangements in use at mercury-using industries. Each design is slightly different in its approach to moving air through the workplace. 


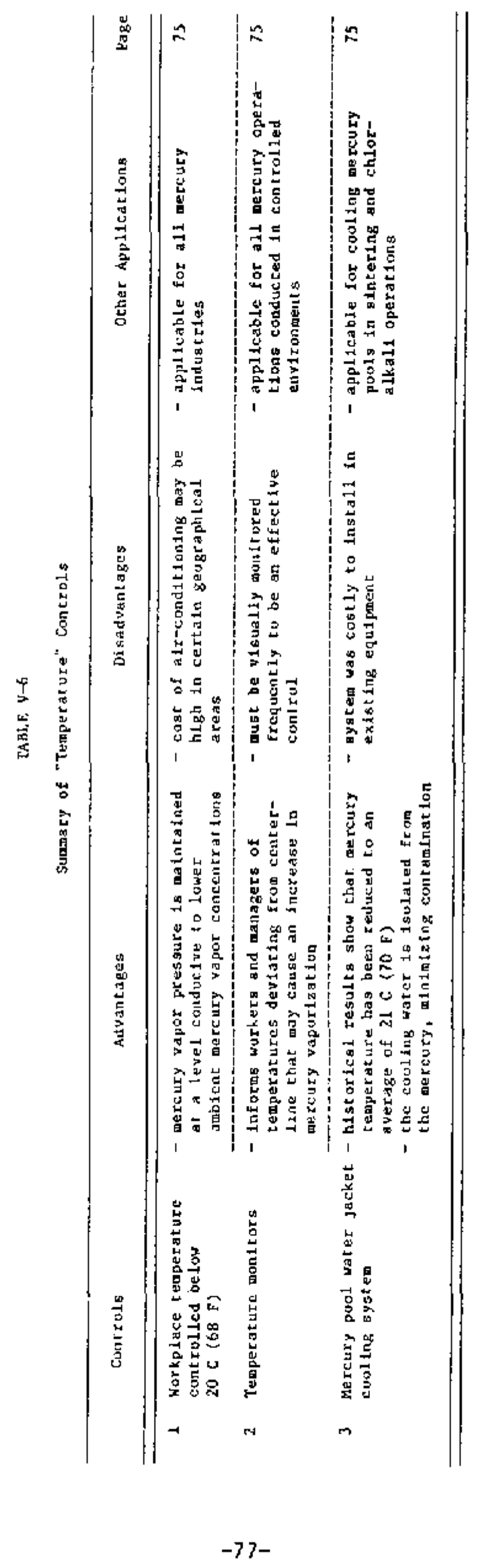


a, Dilution Ventilation Using Air Supply and Exhaust Systems

The mercury fill Room at one mercury switch manufacturer was designed with a separate ventilation system consisting of a 5,000-cfm (design) air supply system and a 5,500-cfin (design) alr exhaust system. The volume of the room 1s approximately $19,000 \mathrm{cu} f \mathrm{t}$. The 500-cfm difference between air exhausted and air supplied was designed to maintaln a negative pressure in the Fill Room, preventing mercury vapor froto escaping into adjacent assembly areas. Testing atr movement with a smoke tube verifled that this negative pressure was being achieved.

The alr supply system consists of an intake louver, a filter box, and a GE air handler. Air is supplied through five circular celling diffusers. Durfing operating hours $(6 \mathrm{a} . \mathrm{m}$. to $10 \mathrm{p}, \mathrm{m}+)$, supply alr $1 \mathrm{~s} 100$ percent outside a1r. The air exhaust system consistg of a Powerline fan powered by a 1.5horsepower motor. It operates at a suction pressure of 0.25 inches of water. Alr is exhausted from the room through three local exhausts and five floor exhausts. The floor exhausts are retangular ducts that extend from ceiling level to within 5 inches of the floor. The exhaust fan for the entire systen is located on the roof.

To conserve energy, the ventilation system 1n the Fill Room is operated in a partial recirculation mode during nonproduction hours (10 p.m. to $\mathrm{a} a, \mathrm{~m}$. ). There are no workers in the room during this period, and the mercury is not exposed to the ambient air. Recirculation is accompliahed through the use of an exhaust vent situated at celling level in the Fill Room. This vent connects through ductwork to the suction stde of the air handler. At $10 \mathrm{p} . \mathrm{m} .$, an automatic control sybten closes the outaide air louver on the supply system and opens a louver between the recirculation exhaust vent and the air handler. Part of the conditioned air is now recirculated, reducing the energy costs of conditioning outside air.

Another mercury switch manufacturer currently uses a partial recirculation system but is in the process of changing over to a 100 percent outside air system.

The existing air supply system in the mercury Fill Room at the plant delivers approximately 16,000 cfm, utilizing two 8,000-cfm Lennox afr handlers. Each unit has a 25-ton carrier cooling coil. It is a constant volume, variable temperature system that supplies about 80 percent makeup air to the room. An Economizer control system regulates the air by automatically controling dampers. This allows for intake of outside air or preconditioned air from another part of the plant. Intake from these two sources is balanced to minimize the cemperature adjustment needed. However, plant representatives feel that this system is not working optimally and a new a1r supply system Is being designed to replace the north alr handler.

The proposed $\$ 150,000$ air supply unit is a single 120 -ton $(1,440,000$ Btu/ hour) alr handler destgned ta supply $\mathbf{1 6 , 0 0 0} \mathrm{cfm}$ of outside makeup air at a remperature of $19 \mathrm{C}(66 \mathrm{~F})$ Heating capacity for the new unit will be $1,250,000 \mathrm{Btu} / \mathrm{hour}$. The afr handler will reduce temperature cycling, which results from the Economizer control on the existing unit's alr-conditioner. Four-stage cooling will be accomplished using four 30-ton compressors. Higher energy costs are expected with the new system because only outside alr will be used. The existing south air handler will remalo operational for use as a backup gystem whencver the outside alr temperature exceeds $37,8 \mathrm{C}$ (100 F). 
Fluorescent lamp manufacturers typically have an extensive dilution ventilat1on system because of the large amount of mercury that is heated in the process. Local exhausting of mercury contaminated air is usually not sufflclent to ma1ntaln acceprable workplace mercury vapor concentrations.

One lamp manufacturer has an underground duct system for supplying fresh alr to ventilators along the side walls of the production floor. This alr aupply system was buflt into each of the fluorescent lamp production buildings at the plant to provide the dilution ventilation necessary to control mercury vapor.

An important component of the plant supply air system is the local fresh air supply provided at work stations. A local freah air supply system was installed in one of the lamp production bulldings in 1972 at a cost of $\$ 80,000$. This system supplies dilution air to work stations that typlcally have higher than backirround concentrations of mercury vapor (F1gure V-20). Examples of these areas are the tip-off area on the exhaust mackines and the loading area at the basing machines. The basing machine area has a potential for elevated mercury vapor concentrations because of its proximity to the exhaust machine (point of mercuxy addition). The local air supply is designed to reduce the exposure of the operator working at this station by providing cool fresh air at the worker's breaching zone.
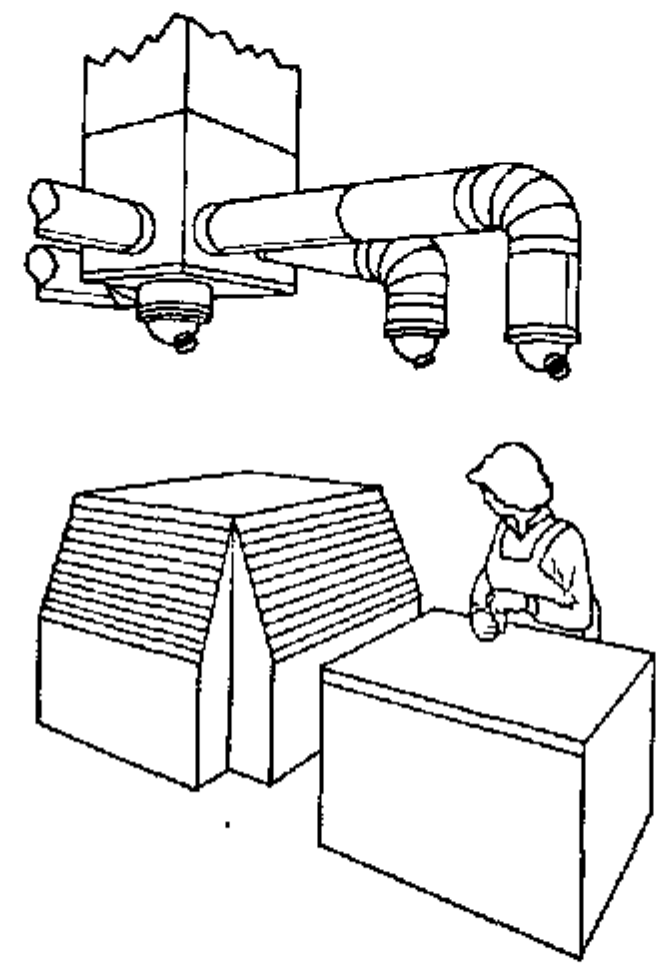

Ffgure V-20. Local Fresh A1r Supply. 
An effective dilution ventilution system that employs local fresh afr supply and unidirectional afrflow across the plant was found at another lamp manufacturing plant. Supply air for the plant 1s provided by 10 ITT Nesbit heating and ventilating units. They provide heated outside air in the winter and untempered outside air in the summer. Roof mounted exhaust air fans are located at the opposite end of the building. The general movement of atr is in through the south side of this plant and out through the north side.

There are several low-capacity blowers used for local supply afr at employee work stations. One such blower provides alr for adjustable 2-1nch clrcular supply vents located in front of each worker on one of the menufacturing machines (Figure $v-21$ ). Each supply vent provides approximately $78 \mathrm{cfm}$ airflow,

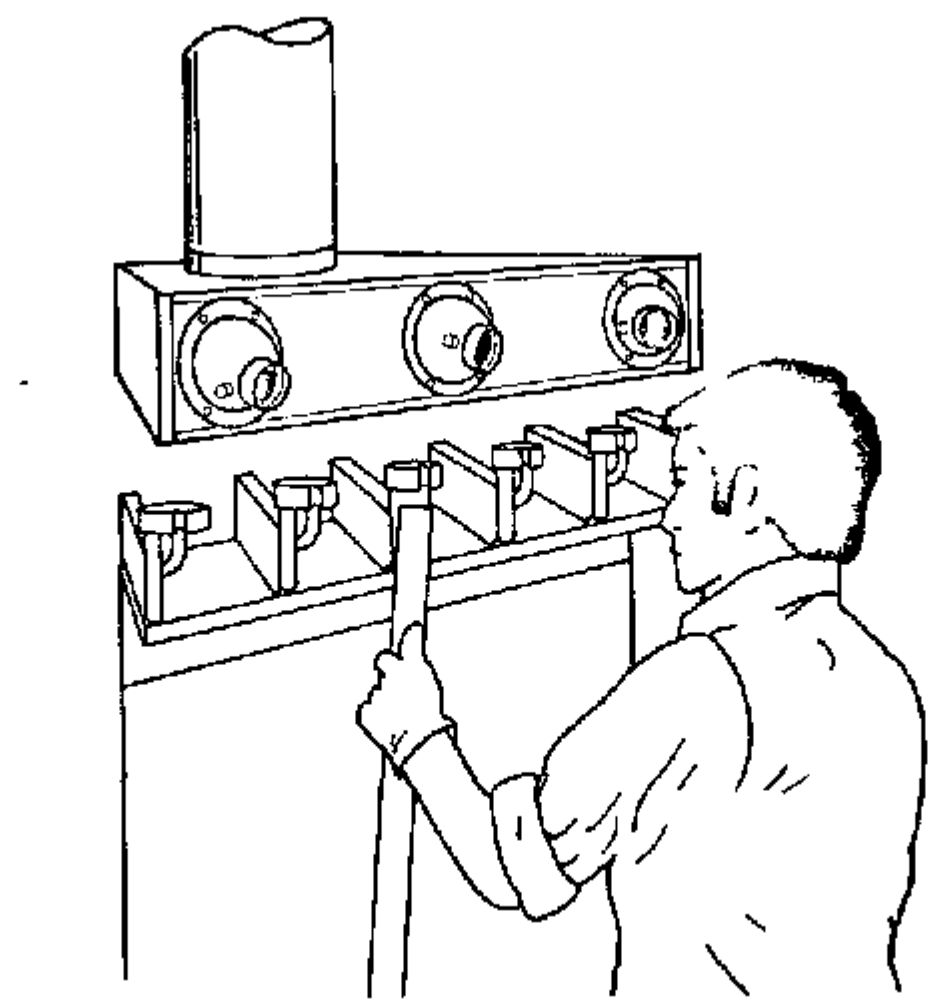

F1gure V-21. Adjustable 2-Inch Supply Atr Vents.

b. Dilution Ventilation by Draft

Some facilities provide dilution ventslation in the workplace without the use of supply air systens. Drafts created by fans or by process heat are often sufflefent to draw dilution alr into buildings through louvers, vents, doors, windows, and open wall panels. 
The concentrator bulding at a mercury mine has a dilution ventilation system consisting of seven roof exhaust fans and three wall intake louvers. The exhaust fans, manufactured by Chicago Blowers, are rated at $16,180 \mathrm{cfm}$ each. The wall louvers are Robertson industrial operating louvers, which are located on the first floor of the buflding. The exhaust fans pull the als through the wall louvers, through the grating between the first and second floors, and out through the roof, thus creating an afrflow up past. the flotation cells. One potential problem associated with this airflow is that mercury vaporizing from materials on the first floor may be carried up through worker breathing zones on the second floor. Plant representatives believe that the dilution ventilation is not the most effective means of controlling mercury vapor concentrations. Efforts to control mercury are concentrated on the removal of mercury vapor at its Bource.

The design of many of the mercury cell rooms used in the chlor-alkali industry permits the movement af a large volume of atr past the mercury cella. The cell room building at one plant is a double-peaked structure with a large, open basement below the cell level (second floor) and a high ceiling above the cell level. There are vents along the roof and vents and removable wall panels along the walls of the bullding. Alr movement in the cell room is achleved through convection currents resulting from the heat of the mercury cells. The temperature differential between the hot afr above the cells and the cooler outside alr causes the hot alr to rise through the roof vents. Cooler outside air in tuxn flows in through the wall vents (opened in the winter) or through the remavable wall panels (opened in the summer). Air grovement between the two floors of the bullding is achieved through the use of fiberglass grating installed on the walkways of the cell level.

A ventilation study conducted at this fac1lity by the plant engineer in 1975 showed that the average air velocity through the roof vents was $225 \mathrm{fpm}$. The total open area of the roof vents was 1,180 square feet. The afrflow through the bullding was calculated to be $265,500 \mathrm{cfm}$. The total air volume of the cell room was 885,000 cu $\mathrm{ft}$.

A summary of the "Dilution Ventflation" controls studied is presented in Table V-7.

\section{Isolation}

At some facilities, mercury operations associated with mercury vapor concentrations approaching or exceeding the OSHA PEL are isolated from other work areas. Th1s practice facilitates the contalnment and removal of mercury contaminated air and reduces the potential for the mercury vapor to spread throughout the workplace. Applications of the isolation method anclude separate rooms with closed doors or separate work areas away from the majortty of workers. Isolated mercury handitng rooms should be under a negative pressure with respect to adjacent work areas to prevent mercury vapor from diffusing into the other areas. 


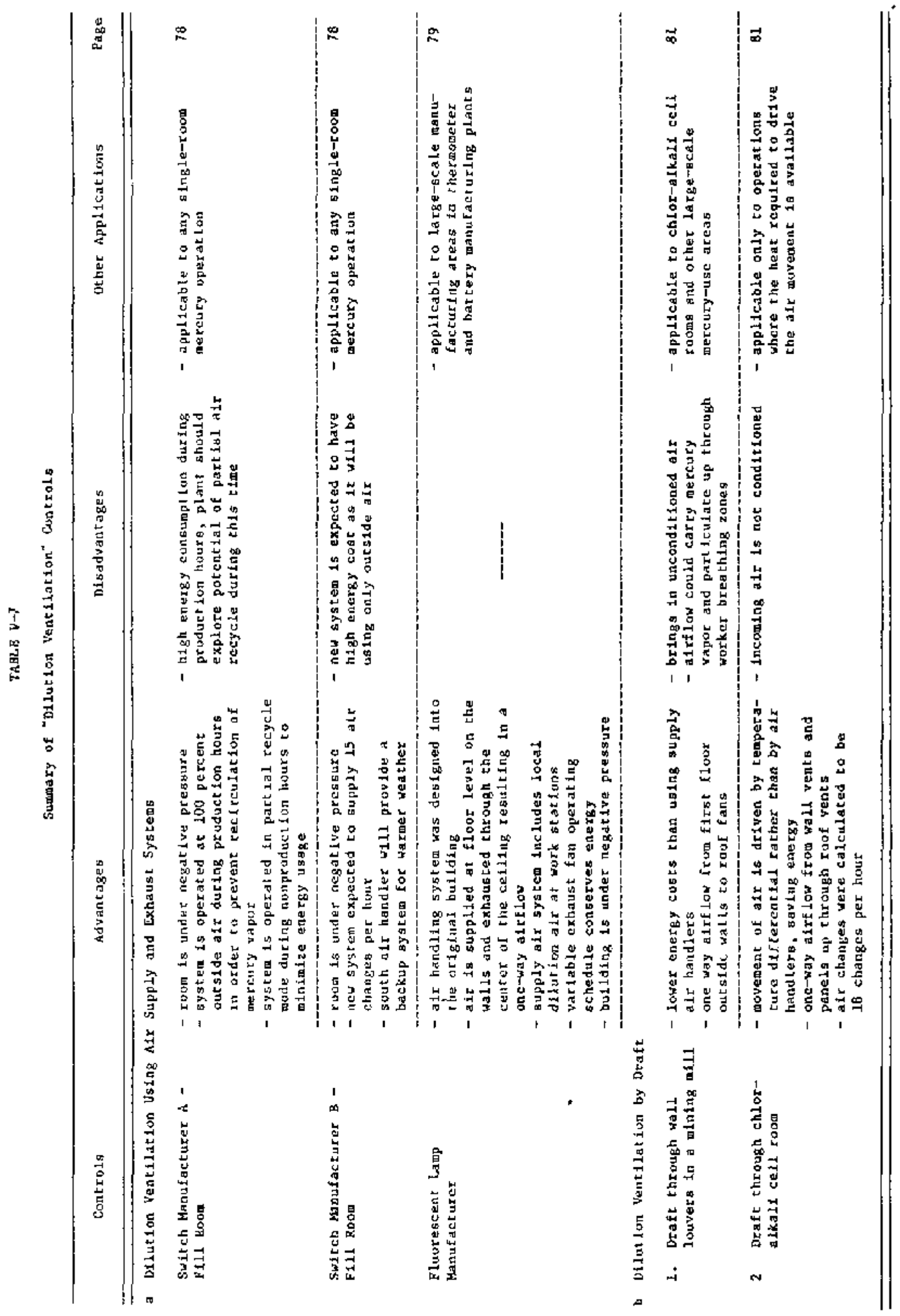


Mercury filling operations, with the exception of fluorescent lamp manufacturing, are typtcally conducted in 1solated rooms in production plants. Thermometer filling equipment, in partleular, 18 usually operated in an isolated area because of the quantity of mexcury handled and the elevated temperature of some operations. Fluorescent lamp manufacturers use 1solated work areas for filling mercury dosers (for exhaust machines) and for performing parts cleaning and malntenance. Mercury chemical production processes that are conducted in different areas of plants are difffcult to isolate because of the large doors needed for moving heavy equipment (forklifta, etc.). Several factilties have solved thls problem through the use of plastic strip doors at room openings, which allow for easier room-to-room movement while adding in the isolation of the mercury use area. Mercury distilling operations periodically cause ambient mercury vapor concentrationg to exceed the OSHA PEL. For this reason, st1lls, ovens, furnaces, retorts, and other equipment used for heating mercury are often situated outside of the main plant or are located in separate isolated bufldings.

The following are brief descriptions of 1golated mercury use areas observed:

- The mercury Fill Room at a thermometer manufacturing plant is isolated from the rest of the manufacturing area. A remote vacuum indicator is located outside of the room so that the operator does not need to enter the Fill Room to check the vacuum being drawn on the filler.

- $\Lambda$ thermometer manufacturer has taken stepa to separate the mercury uge area from the rest of the manufacturing areas by constructing a partial wall using 2- by 4-foot panels. This was constructed in 1977 at a cost of $\$ 578$. In addition to this, a wall was constructed to separate the mercury F111 Room from the rest of the mercury use area. This was done in 1977 at a cost of $\$ 900$.

- The mercury use area has beer isolated from the rest of the manufacturing area at a mercury switch manufacturing facility because of widespread mercury contamination during the early years of plant operation.

A summary of "Isolation" controls studied is presented in Table $\mathrm{V}-8$.

\section{Mercury Removal from Airstreams}

Many local exhaust ventilation systems and recirculatiog ventilation systems are used in conjunction with a mercury removal system to reduce mercury vapor/particulate concentrations in air that is released to the atmosphere or returned to the workplace. The removal of mercury from alrstreams aids in meeting environmental and occupational health standards and, if the afr is rectrculated, reduces the energy costs of conditioning a1x. 


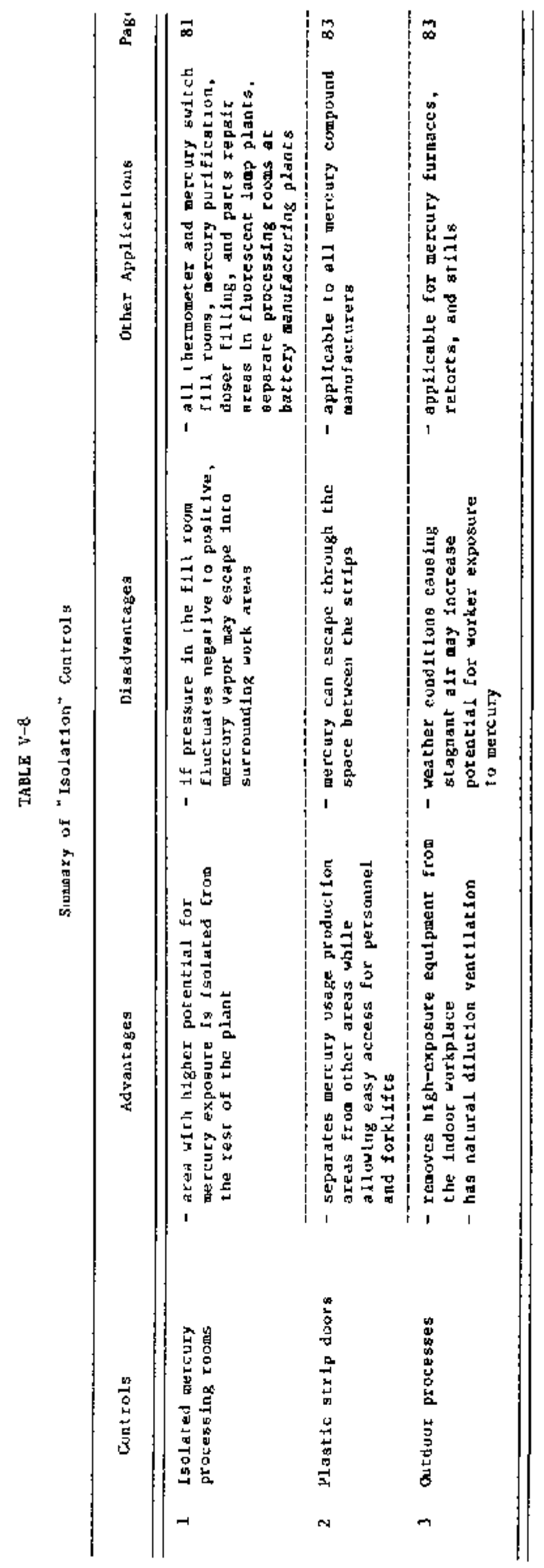


a. Removal of Mercury from Local Exhaust Alrstreams

one chlor-alkali plant surveyed uses a mercury vapor removal system on the exhaust airstream from the ventllated enclosures used to remove mercury vapor generated at the inlet and outlet boxes of the mercury cell. The components of the air treatment system, which include cooling, separation, and adsorption units, are illustrated in Figure V-22. Adsorption of mercury vapor Is accomplished using a Pura-Siv ${ }^{R}$ mercury adsorption unit, manufactured by Union Carbide. It is a dual molecular sieve designed to operate with one sleve (adsorber) in service and the other sieve fn regenexation.

During operation, mercury in the alrstream is adsorbed in the sfeve through a proprietary process. During regeneration, heated $204 \mathrm{C}$ (400 F) "low mercury content" gas is passed back through the sleve, vaporialing the collected mercury and carrying it through a cooler to a Peterson centrifugal separator. The liquid mercury is recovered and reused in the process.

Testing of the unf by both plant engineers and a private contractor showed that effluent mercury concentrations of $0.2 \mathrm{mg} / \mathrm{m}^{3}$ were achieved with influent concentrations of $9-10 \mathrm{mg} / \mathrm{m}^{3}$ during a typlcal 24-hour operating run.

The ventflated enclosures used to remove mercury vapor generated from mercury wells at an electroplating plant are vented through Calgon vent-sorb filters. The filter housing is a 55-gallon drum with openings for alr intake and discharge. The filter media in the Calgon Vent-sorb (approximately 150 pounds in each unit) consists of Fittsburgh Type HGR sulfur-impregnated, activated carbon specially designed for removing mexcury fron atr, hydrogen, and other gases. The HGR contains 13 percent elemental sulfur that 1 s distributed throughout the porous carbon granules. The carbon has a high surface area ( 5 milion square feet per pound) that enhances contact with the airstream. As the mercury vapor in the exhaust atream passes through the filter, it reacts rapidly with the sulfur to form mercuric sulfide.

Care must be taken that the flow of air through each f11ter does not exceed so cfm, since a minimu contact time is required for efficient mercury removal. The fliler media is replaced when mercury vapor concentrations at the discharge of the blower exceed $0.1 \mathrm{mg} / \mathrm{m}^{3}$, as measured with a mercury vapor detector.

b. Removal of Mercury in Recirculating Ventilation Systems

Plants using recirculating dilution ventilation gystems genera1ly employ charcoal or particulate filters to remove mercury vapor or particulate from the airstream before returning the atr to the workplace. Care must be taken that the fflters are replaced when the mercury concentrations at the system discharge begin to tise. Otherwiae, contaminated air is returned to the workplace.

The recirculating system for the Cell Assembly Room at one battery manufacturing plant surveyed is destgaed to remove both mercury vapor and particulate. The systen consists of two separate alr handling/filtering units, 


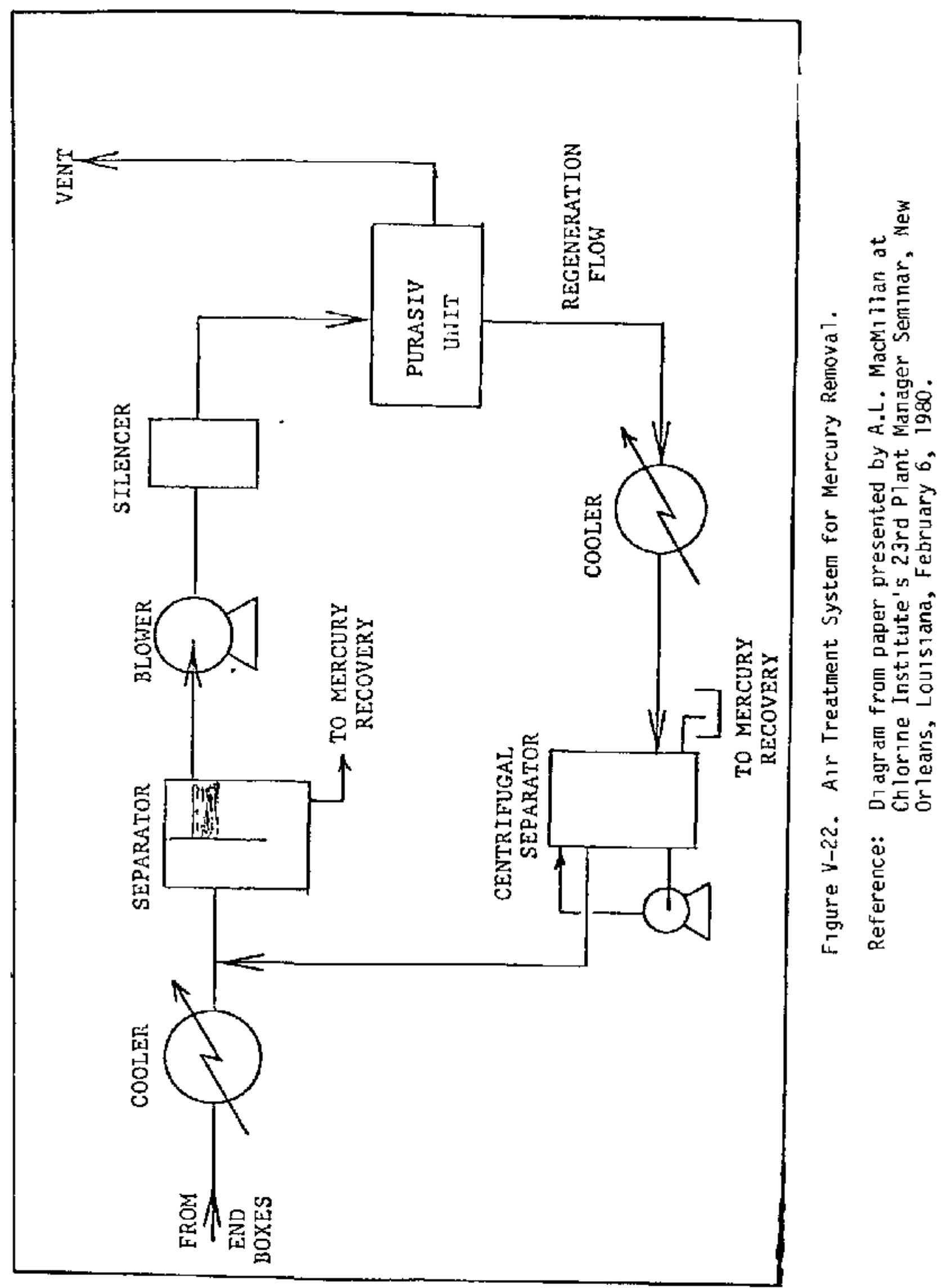


each with one 27-square-foot intake and a network of distributors (Figure $v-23)$. The air handing units are mounted parallel on the roof of the building. They are large "walk-in" units that have been modified to 1mprove mercury vapor removal and reduce ftlter replacement costs. Each air handler in the origiral system, Installed by Industrtal A1r, Inc., Greensboro, North Carolina, consisted of the following components:

1. One centrifugal blower

- manufactured by Eldons Manufacturing Corp., Elgin, Illinols

o $36.5-1$ nch-diameter wheel

o operates at $26,000 \mathrm{cfm}, 3$ Inches stat1c pressure, using a $15-\mathrm{hp}$ motor.

2. One set of 35 percent efficient modular fiber filters

o manufactured by Cambridge Fllter Corp., Syracuse, New York

- 12 filters set inco a ftlter bank measuring $6^{\circ} 2-1 / 2 " \times 8^{*}-3 / 8^{\prime \prime}$.

3. One set of 95 percent effictent modular fiber filters (Figute V-24)

- set inta fllter bank measuring $6^{\prime} 2-1 / 2^{\prime \prime} \times 8^{1}-3 / 8^{\prime \prime}$

- each filter contalning 120 square feet of filter media area.

4. One set of 95 percent efficient charcoal filters

o manufactured by Barneby-Cheney

o 144 filter trays set at an locline into an 8- by 6-foot filter rack

a a total of $33.7 \mathrm{cu} \mathrm{ft}$ of filter media in the filter rack

- approximately $\$ 64$ per tray

o each tray consists of lodine-1mpregnated charcoal pressed between metal screens.

5. One set of cooling colls

6. One set of steam colls

The 35 percent efficient particulate filters were replaced monthly, and the 95 percent efficient particulate filters were replaced yearly. plant representatives found that the charcoal filters achfeved 86 percent efficient 


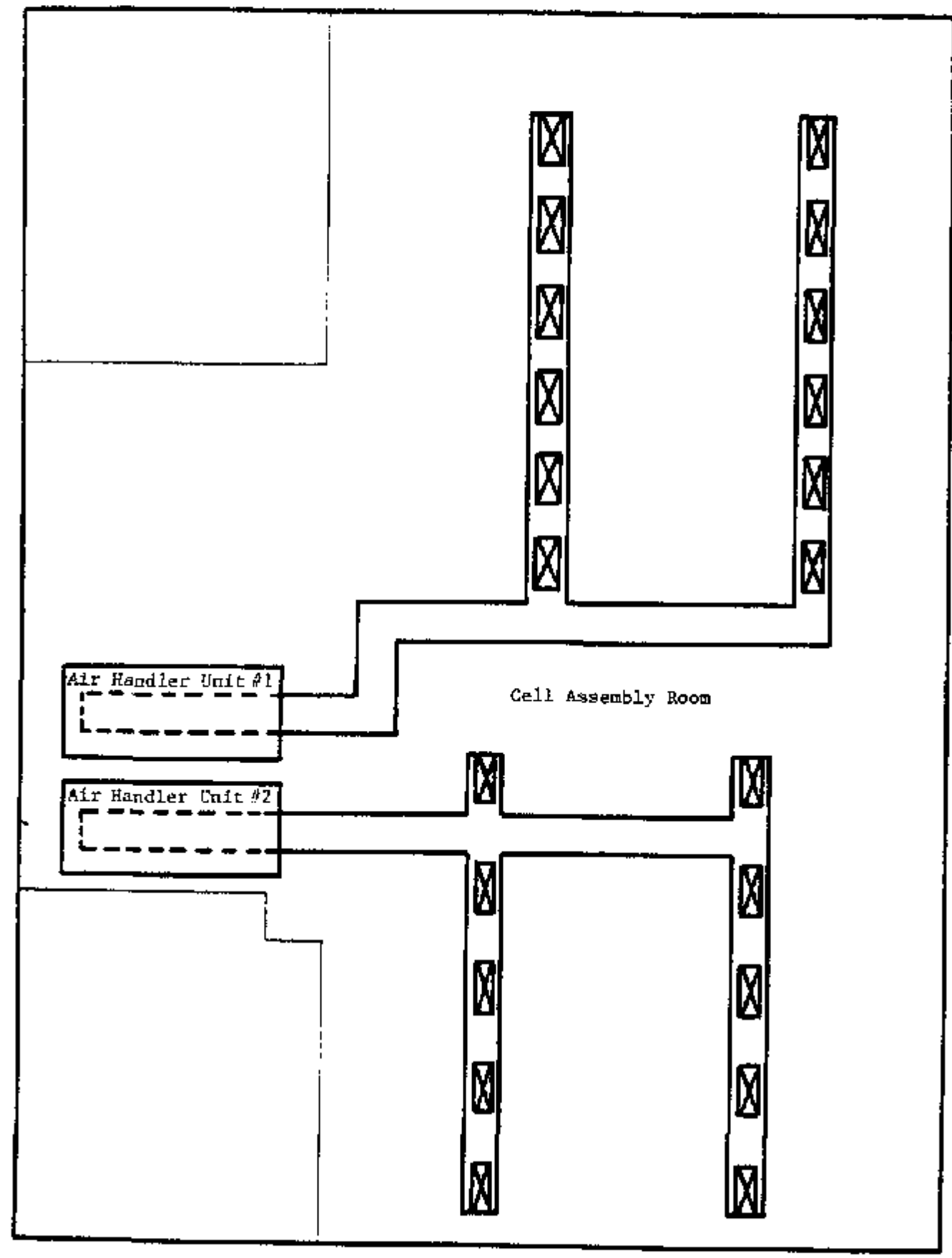

Figure V-23. Schematic of Recirculating Air System. 


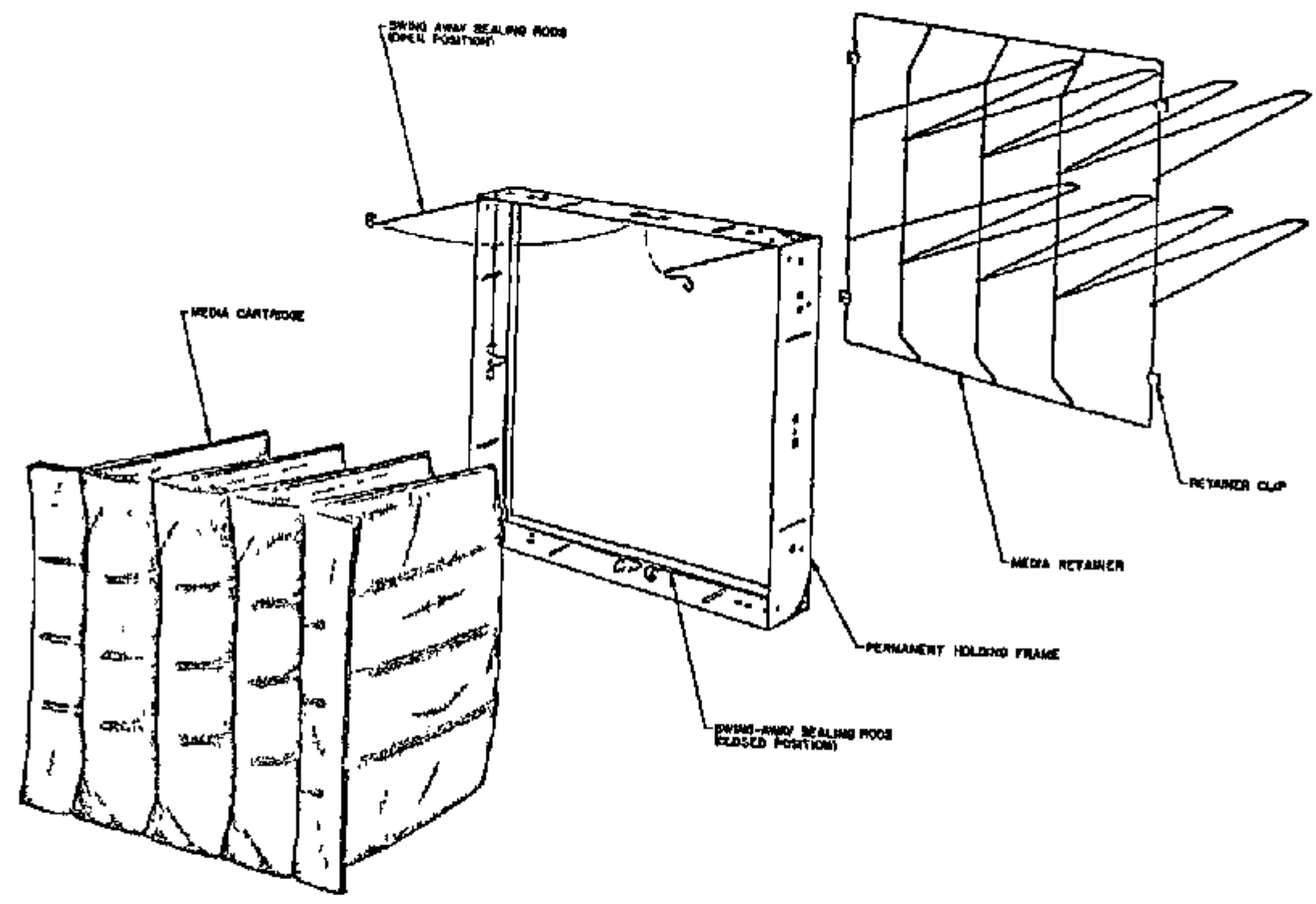

Figure V-24. Fiber Filters for Particulate Remaval.

mercury vapor removal when initially installed. When the efficlency fell to 60 percent, based on readings taken with a mercury vapor detector, new filters were ordered. The filter trays were replaced when the efficiency fell to 50 percent (replaced approximately once per year).

In 1982, plant representatives began efforts to reduce filter costs while maintafing reduced mercury vapor concentrations. They installed a second charcoal filter bank to utilize the 50 percent efficlent filters rather than discarding them. A new filter bank was 1natalled behind the original one. The 50 percent effictent filters were moved to the front rack and new filters were installed $I n$ the back rack. The filter replacement procedure was changed to the following.

- When total efflciency falls to 60 percent, order new filters.

o When total efflclency falls to 50 percent, discard front-rack filters and move back-rack filters to front. Install new filters on back rack. 
The pressure drop resulting from the addition of another filter bank neceasitated an increase in air handler capacity. The layout of the air handler housing prohibited the installation of a larger fan, therefore, the plant installed an additonal $26,500-\mathrm{cm}$ blower in each atr handling system. The resulting configuration was two blowers operating in series with the filter banks and conditioning colls situated between them. The original and madifled configurations are illustrated in Figure V-25.

The charcoal filter trays are front or side loaded horlzontally at a sifght angle $i n$ the filter rack. The edges of the trays are connected in a conttnwous zig-zag configuration through the use of compression fittings (Figure $\mathrm{V}-26$ ). An effective seal is made when the alrflow through the unit forces the surface of connecting tray edges against the fitting. plant representatives stated that clamped connections would provide a more effective seal, but they are not cost-effective.

This recirculating system is also designed with fresh alr makeup capabilities. An Economizer controller system is used to open outside air louvers when $1 \mathrm{t}$ is more efficlent to condition workplace alr with outside air. This louver was closed during most of the site visit.

Ventilation measurements, taken in alr handler vnit No. 1 during the survey, showed that the actual alrflow achieved using the two fans in series was $38,600 \mathrm{cfm}$ (average of four measurements taken in the plenun between the fans). The airflow measured at the inplant afr intake for the air handler was $27,200 \mathrm{cfm}$. The discrepancy between these two afrflows 1s accounted for by an estimated 6,000-10,000 cfm that was leaking through the "closed" fresh anr intake lowvers. Therefore, the air handlex was actually operating in approximately a 75 percent recirculating mode. The mercury removal efficiency of the alr system was determined using a mercury vapor detector at the upstream and downstream sides of the charcoal filter banks. The average mercury vapor concentration upstream of the charcoal filters was $0.030 \mathrm{mg} / \mathrm{m}^{3}$. The average mercury vapor concentration downstream of the filters was 0.008 $\mathrm{mg} / \mathrm{m}^{3}$. The average removal efficlency for four separate determinations was 73 percent.

Another battery manufacturer recovers the heat of the workplace a1r without recycling the air itself. Three of the mercury handling rooms at the plant are serviced by two exhaust/supply systems. Each system has an Induced draft blower (that draws exhaust air through a baghouse), a heat exchanger, and a charcoal filter. The alr is exhausted through a stack. The heat exchanger recovers heat from the exhaust afr and uses tt to preheat outside supply afr drawn by a blower adjacent to the exhaust unit.

Some plants use mercury-filtering air units situated entirely within the workplace to help remove mercury vapor. A mercury disttller and bottler uses a precoat bag filter system to remove mercury vapor from plant air. The system consists of a Torit Model No. 125-50 "dust collectlon" undt (Figure V-27) manufactured by the Torit Diviston of the Donaldson Company, St. Pau1, Minnesota, The cost of the Torit was $\$ 6,735$ in 1976 . The unit draws plant air from three different rooms. In each room, the air is drawn through a 4- by 10-1nch intake duct. The ducts from the three sources connect at a junction box adjacent to the Torit, and the flows combine to pass through the filter unit. The precoat media on the filter bag 


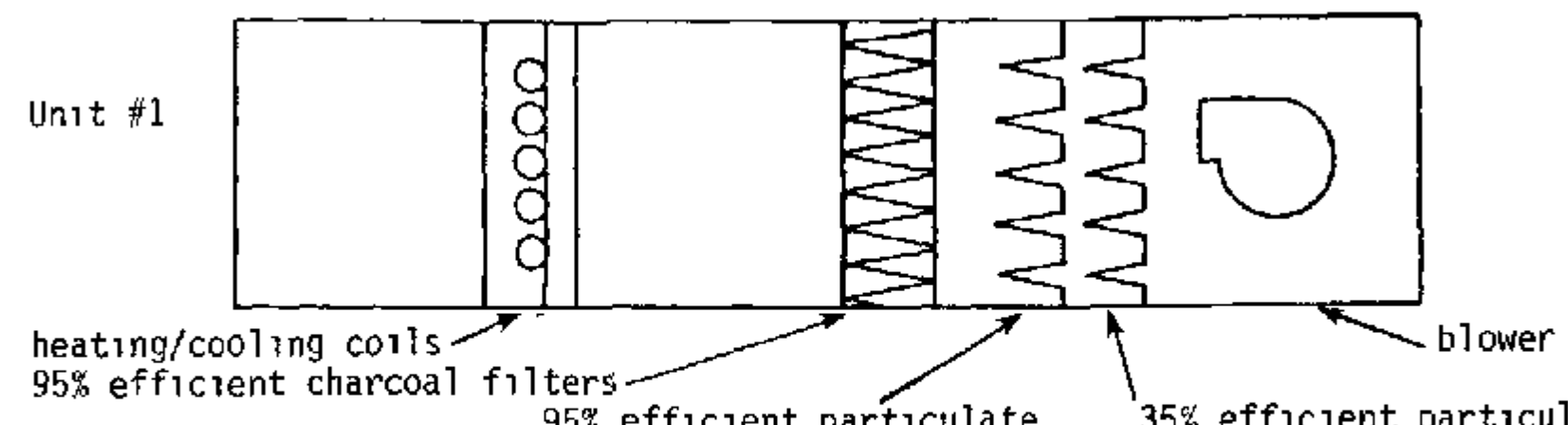
95\% efficient particulate $35 \%$ efficient particulate filters f 1 ters

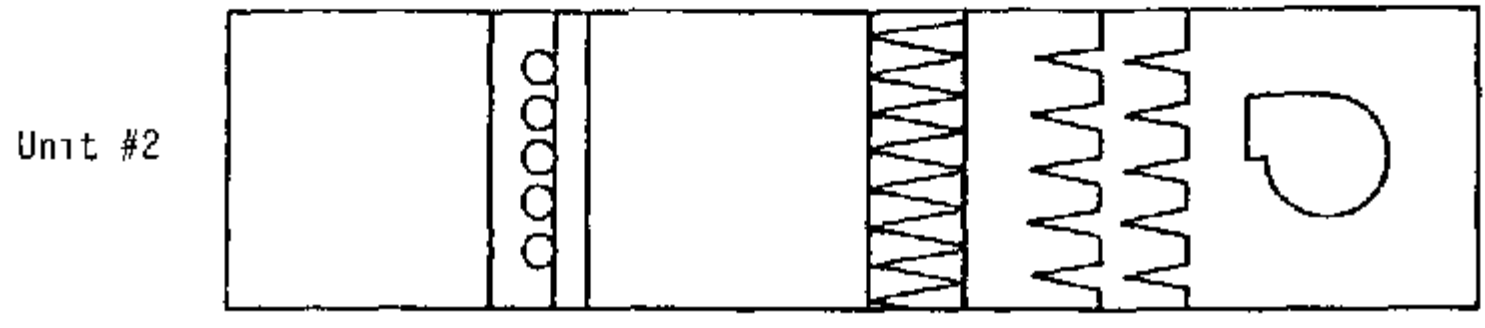

Original Configuration

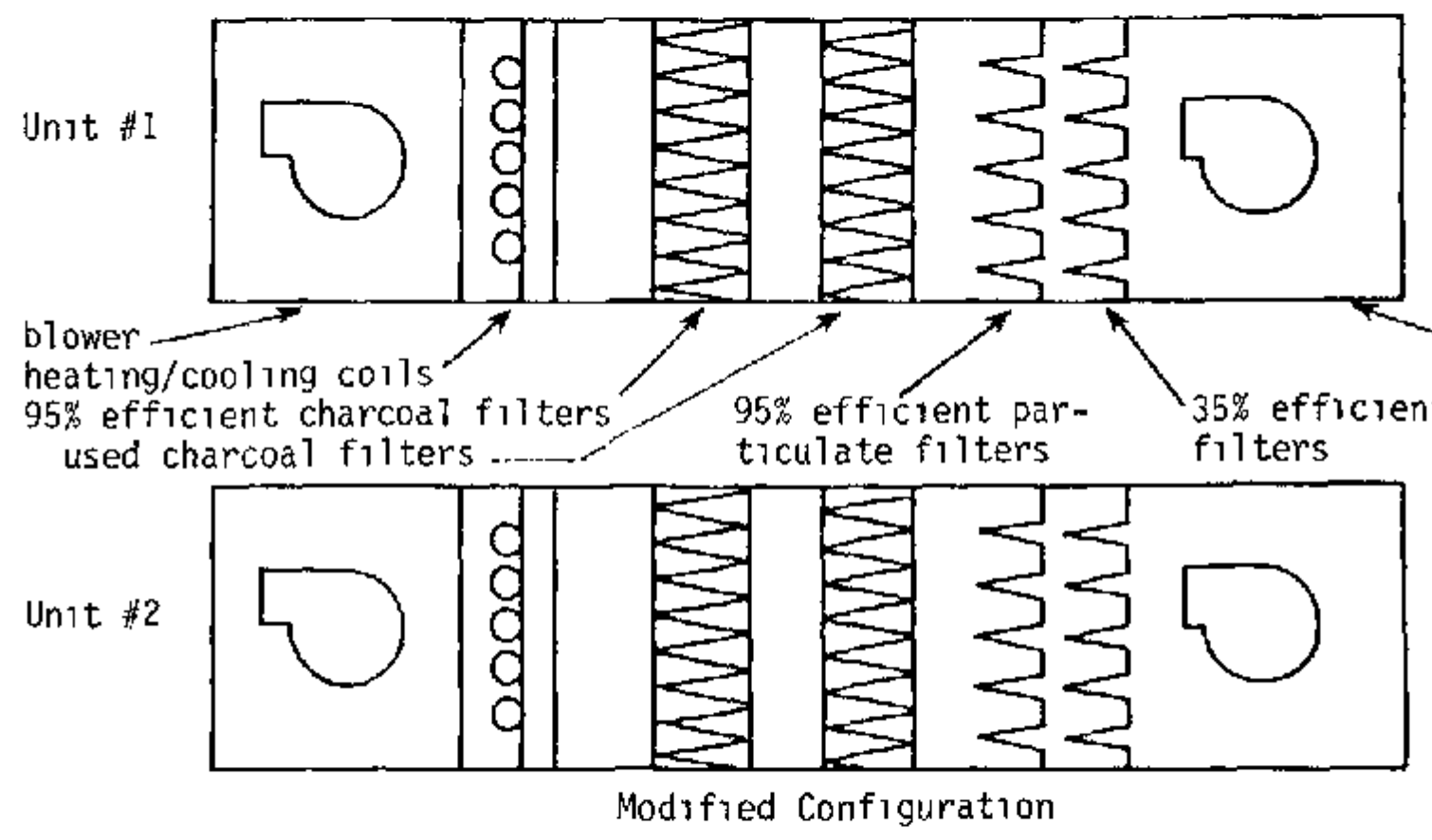

Figure V-25. Original and Modified A1r Handler Configurations. 

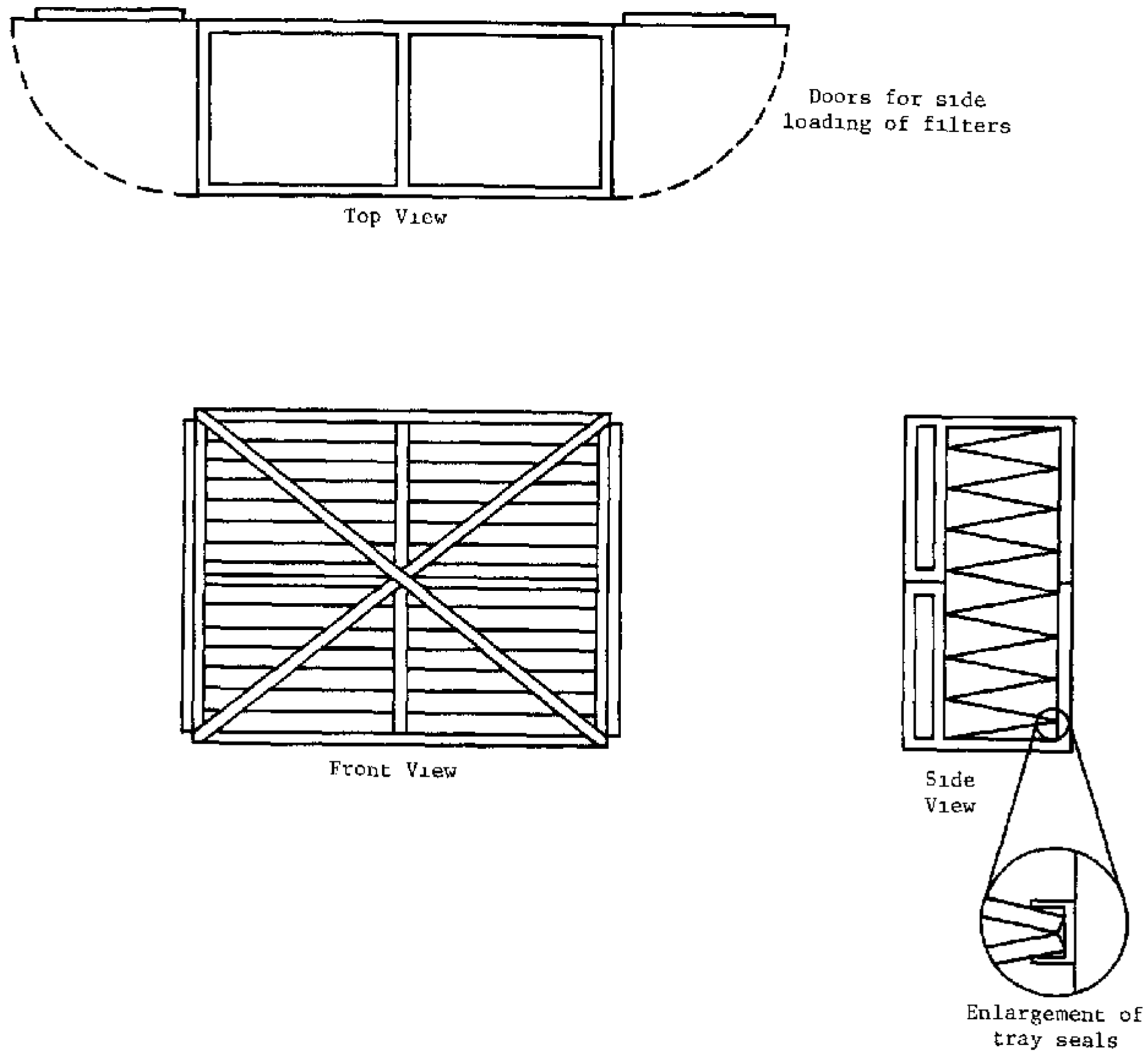

Figure V-26. Charcoal Filter Rack Configuration. 


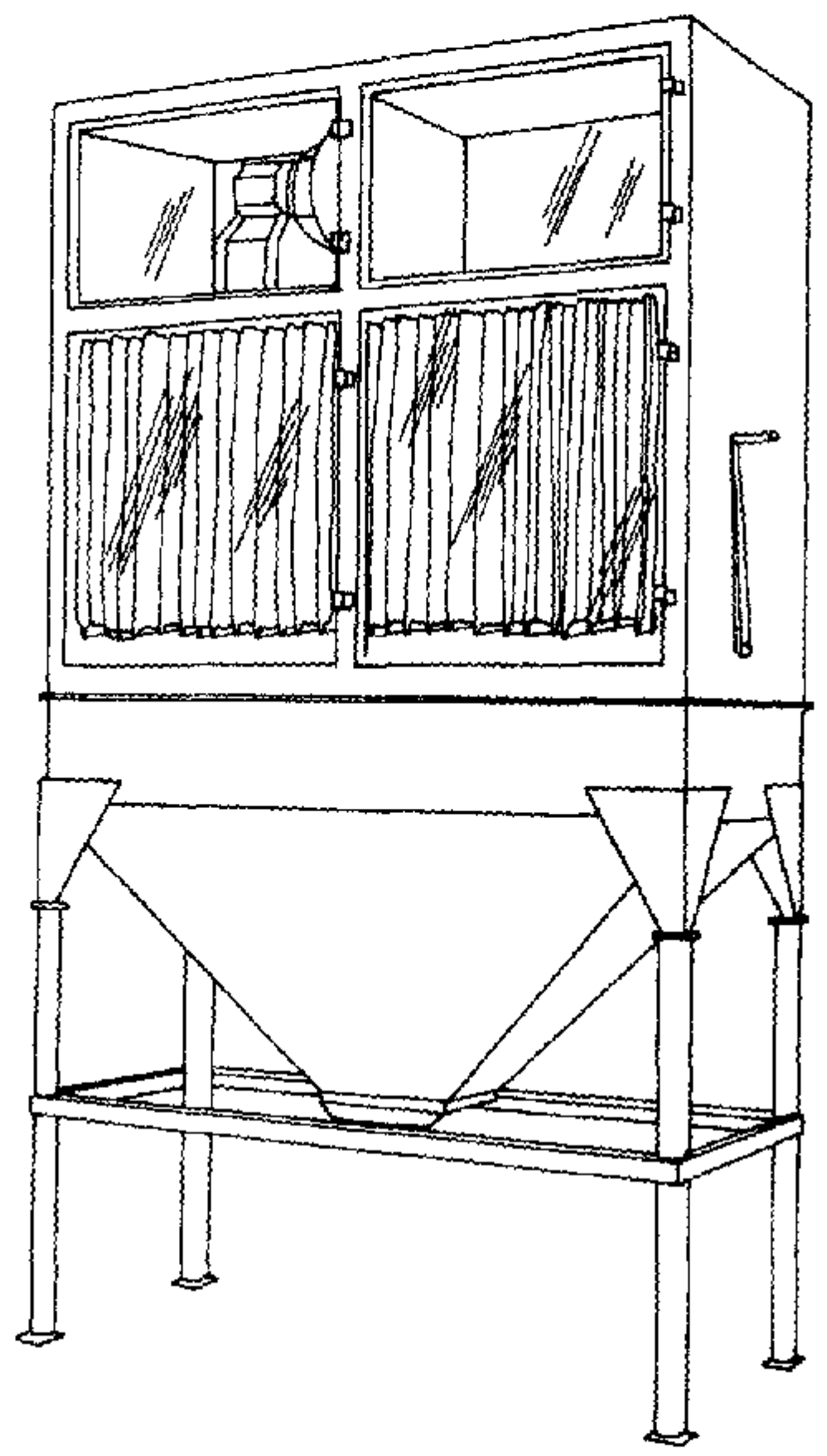

Ftguxe V-27. Torft Dust Collection Unit. 
cartrldges is manganese dioxide. Manganese dioxide adsorbs the mercury vapor and removes it from the a1rstream. The mercury vapor concentration in the afr from the Torit unfl is monitored periodically, and the manganese dioxide is discharged and replaced when the concentration exceeds $0.1 \mathrm{mg} / \mathrm{m}^{3}$. At present, the manganese dloxtde 18 shaken down and replenlshed on a weekly basis.

The Tortt consists of a chemical charging hopper, a series of fllter bags, a blower, a discharge conduit, a shakedown valve, and a shakedown tray. The charging hopper is the junction box where the flows combine from the three exhaust takeoffa. It is a rectangular section of duct with a sheet metal door. To charge the unit with manganese dfoxide, the door is opened while the blower is operating and the manganese dloxide is poured in until a pressure drop of 3 inches of water is achieved across the unit. This provides an airflow of approximately 3,000 cfin through the Tortt. The pressure drop is determined by reading a pressure gauge on the side of the unit.

The filter section of the Torit consists of 36 cloth filter bags with wire mesh frames. Approximately twice a week, the Torit is shut off and the manganese dioxide is shaken down from the bags into a shakedown tray using a crank on the side of the Torit. The Torit 1s then started up agan and the manganese dioxide is drawn back onto the bags. This practice helps to ensure that an even precoat remains on the filter bags. When the manganese dfoxide is being replaced, the used powder is removed from the shakedown tray.

The blower, powered by a 5 -hp motor, draws alr through the filter bags and into a suction plenum. It exhausts into a discharge plenum mounted above 1t. The discharge plenum has a 14- by lo-inch opening through which the exhaust air 18 released to the work area at celling level. Manganese dioxide was found at the discharge of the unit. A hole found in one of the filter bags could be contributing to this filter media breakthrough.

The measured a1rflows from the three exhaust ducts were $780 \mathrm{cfm}, 610 \mathrm{cfm}$, and $1,100 \mathrm{cfm}$. The total a1rflow through the Torit is therefore approximately $2,500 \mathrm{cfm}$. The mercury removal efficiency of the unit was calculated to be 76 percent.

Smaller units designed for removing mercury from workplace atr are used for swall-scale mercury handling operations. One such unit in use at an electrical standards manufacturer is a recirculating air filter unit manufactured by Barneby-Cheney, Columbus, ohio. This self-cantalned unit, sttuated in the standacds lab, conglats of a $1,000-c f m$, three-speed fan and an activated charcoal filter mounted inside of a casing with approximate dimensions of 1.5 feet by 1.5 feet by 4.5 feet high. The air tatake is at floor level and the exhaust is at the top of the unit. The filters are arranged in a series of three. The unit is portable and can be moved to any location in the room. The cost of this unit, purchased in August 1980 , was $\$ 2,300$, including replacement charcoal filters. Information on the mercury vapor removal. efficlency of this unit was not avallable.

A summary of "Mercury Removal from Atrstreams" controls is presented in Table V-9. 


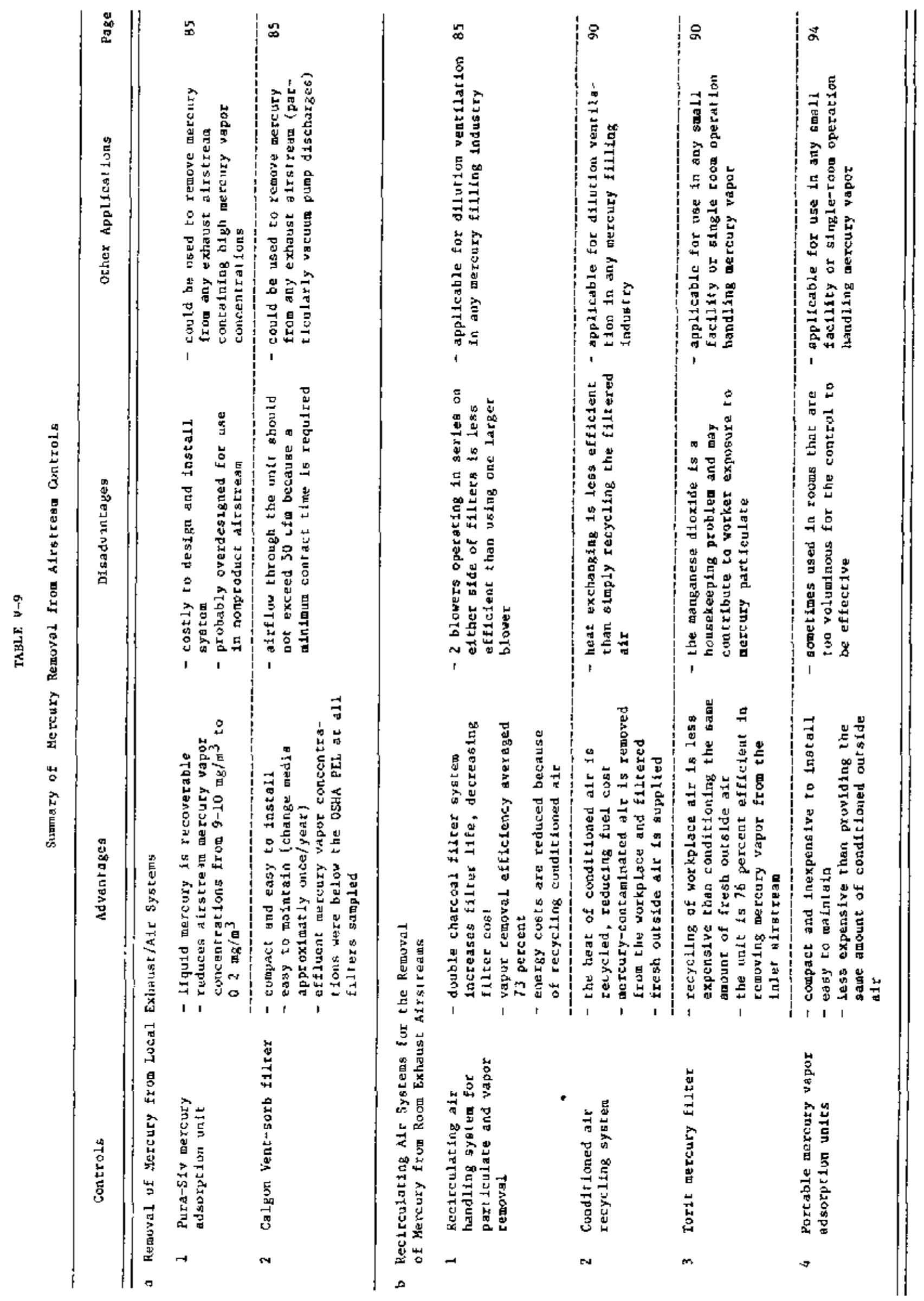


The physical properties of elemental mercury (liquid state at room temperature, vapor pressure, and abllity to cling to skin and clothing) and fnorganic mercury compounds (case of dispersion and high vapor pressure) make it difficult to control worker exposure through engineering controls alone. Most facilities using inorganic mercury have found it necessary to implement a comprehensive control system including behavioral contrals snd personal protective equipment (discussed in the following section) in order to eliminate exposure or reduce it ta acceptable levels. All of the plants surveyed during this study employed behavioral controls to supplement engineer 1 ing controls.

A sumary of the various behavioral controls implemented to reduce worker exposure to mercury ts presented in Table $V-10$.

1. Housekeeping

The housekeeping practices listed in Table V-10 are those used by industry on a routine basis.

a. Mercury Decontaminants

Most Industries surveyed used a mercury decontaminant and mercury vapor suppressant cleaning aid as part of their routine housekeeping progran. HgX (a proprietary polysulfide compound) was the most commonly used cleaning ald. Other cleaning aids included sodium sulfide and calcium polysulfide. All three compounds are reported to work by binding with elemental mercury and mercury compounds, thereby prevent 1 g vaporzzation and facilitating cleanup. A mixture of equal proportions of powdered zinc and sawdust was used to ald in cleaning mercury spills at one facility studied. A sumary of common applications of mercury decontaminants is contained in Table V-1l.

b. Vacuum Cleaners

Many plants surveyed relied on the use of specially designed vacuum cleaners for both routlne cleanup and cleanup of major sp111s. These vacuum cleaners are generally modified versions of industrial vacuum cleaners that have been specially adapted for use with mercury.

These vacuum cleaners are mobile, stalnless steel can-style units usually equipped with a 1.5-1nch-diameter suction hose, vacuum pump, Inilne mercury trap, and vapor or particulate fllter. They typically provide an alrflow of approximately $80 \mathrm{cfm}$ and a maximum vacuum of 70 inches of water. The lnline mercury trap is used to collect mercury before it reaches the vacuum punp. The trap is usually a small removable plastic container. The vacuum cleaners contan both charcoel filters and high-efficiency particulate air filters. Charcoal Ellters are used to remove mercury vapor from the vacuum pump discharge. HBPA fllters are effectlve la removing mercury particulate (oxide, etc.) frow the discharge alrstream. Filters must be changed periodically. Most vacuums have an "hours of service meter" that indicates filter replacement time. Alternatuvely, the discharge of the vacuum cleaner can be monitored using a mercury vapor detector to determine end of filter life. Marcury vacuum cleaners from four manufacturers were in use at the industries studied. They are Ntlfisk, King of Frussia, PA, American Cleaning Equipment, Addison, IL, National Super Service, Toledo, OH, bayton Electrical Mfg., Chlcago, IL. 


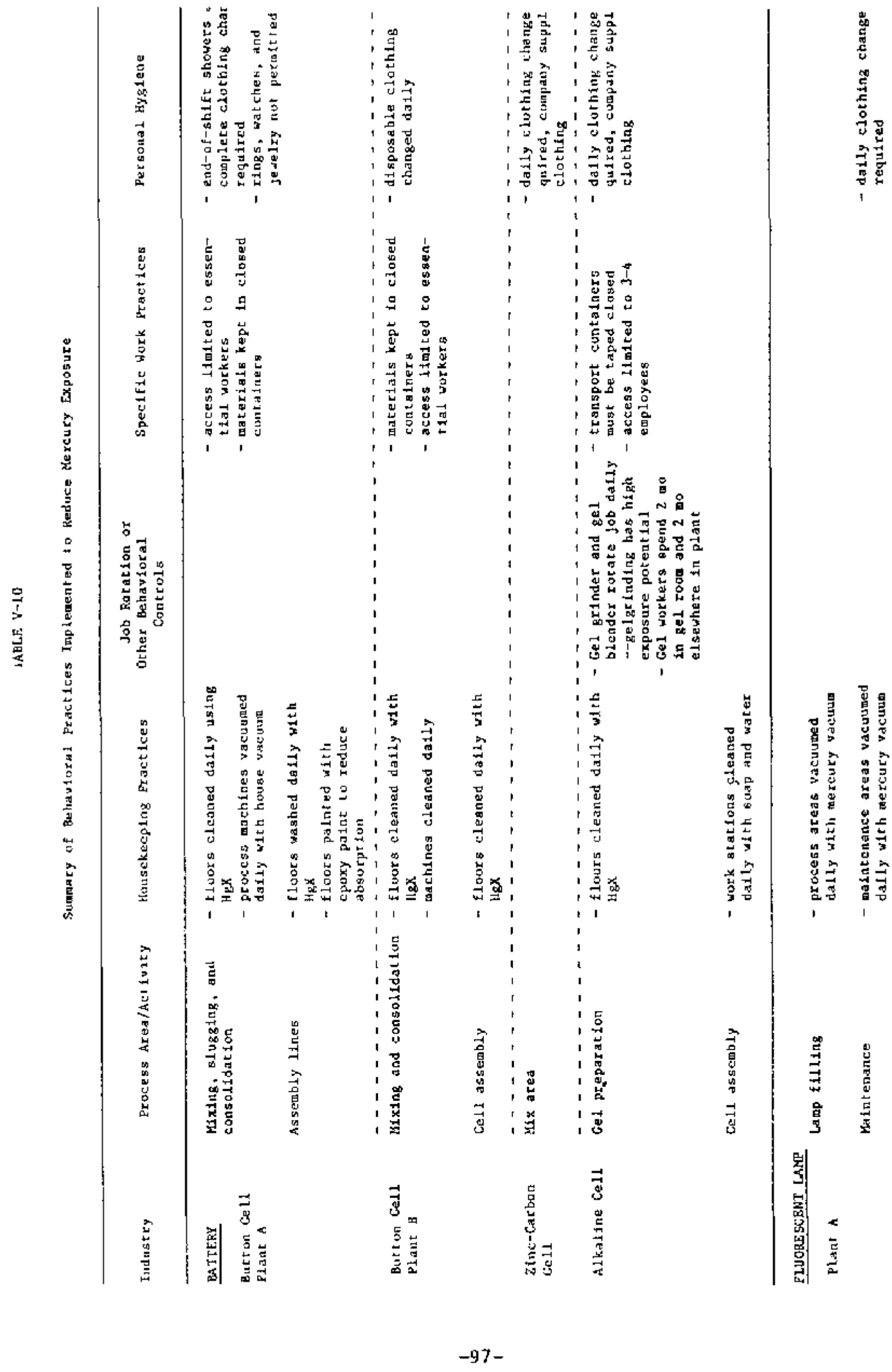




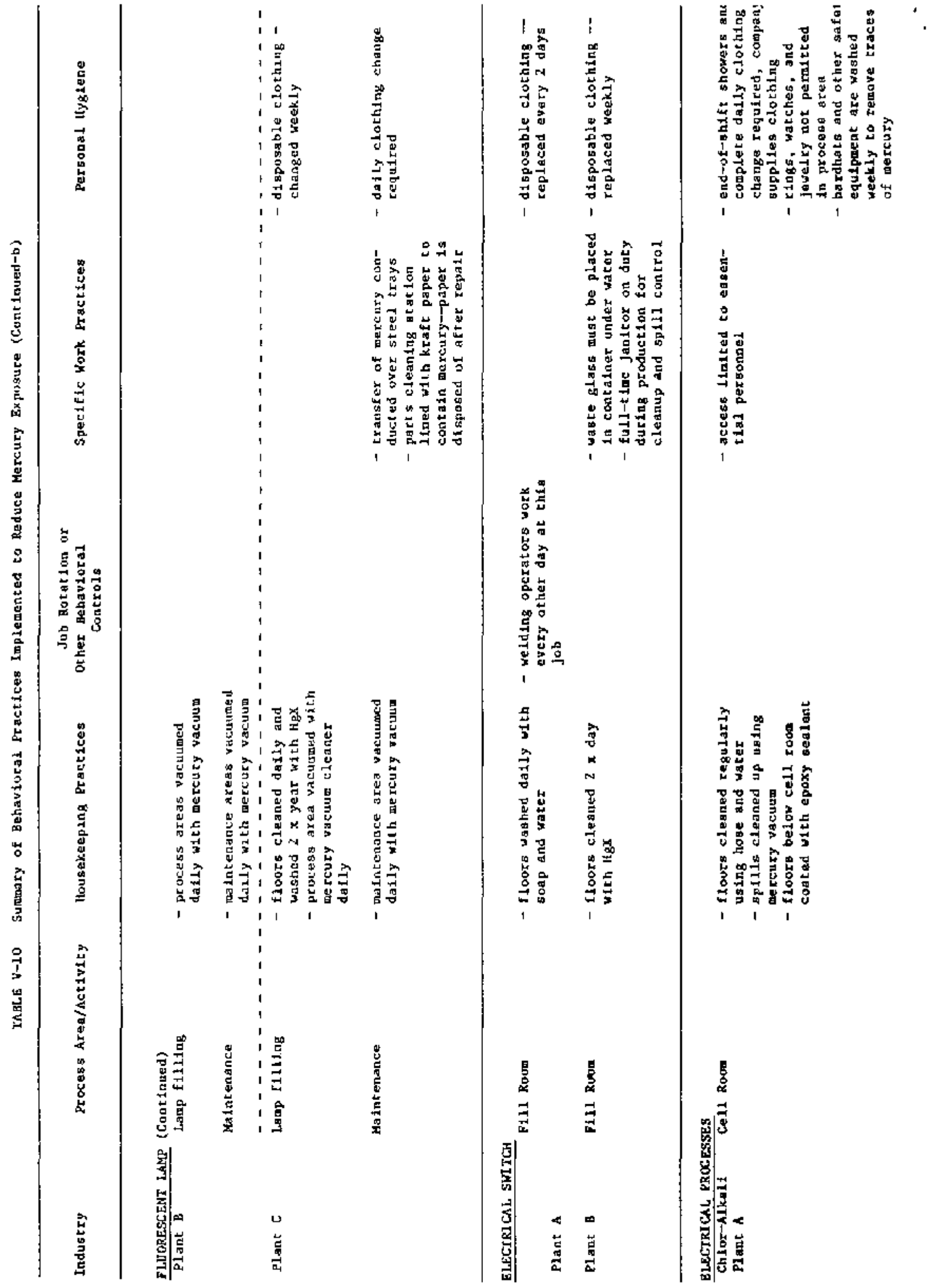




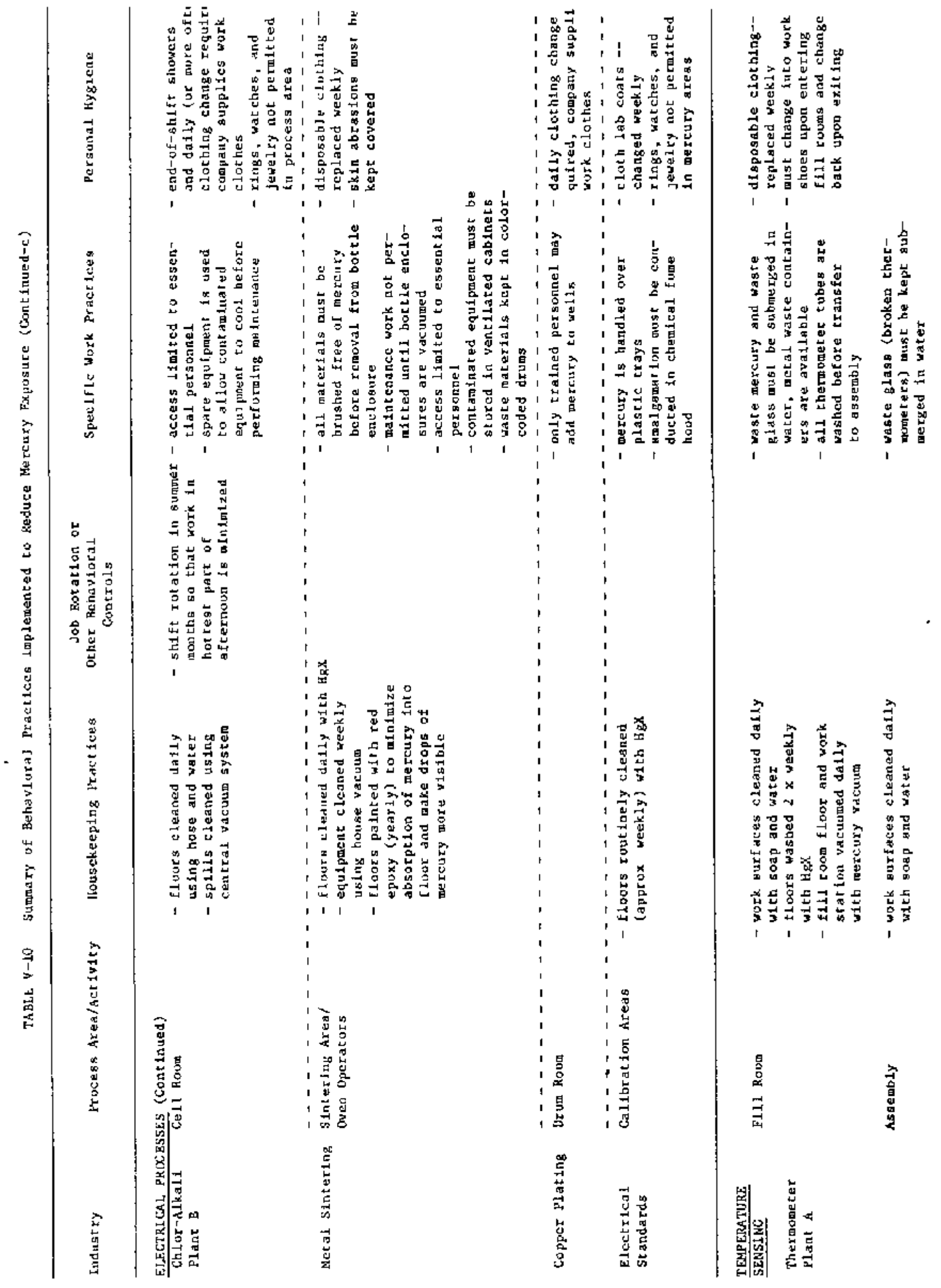




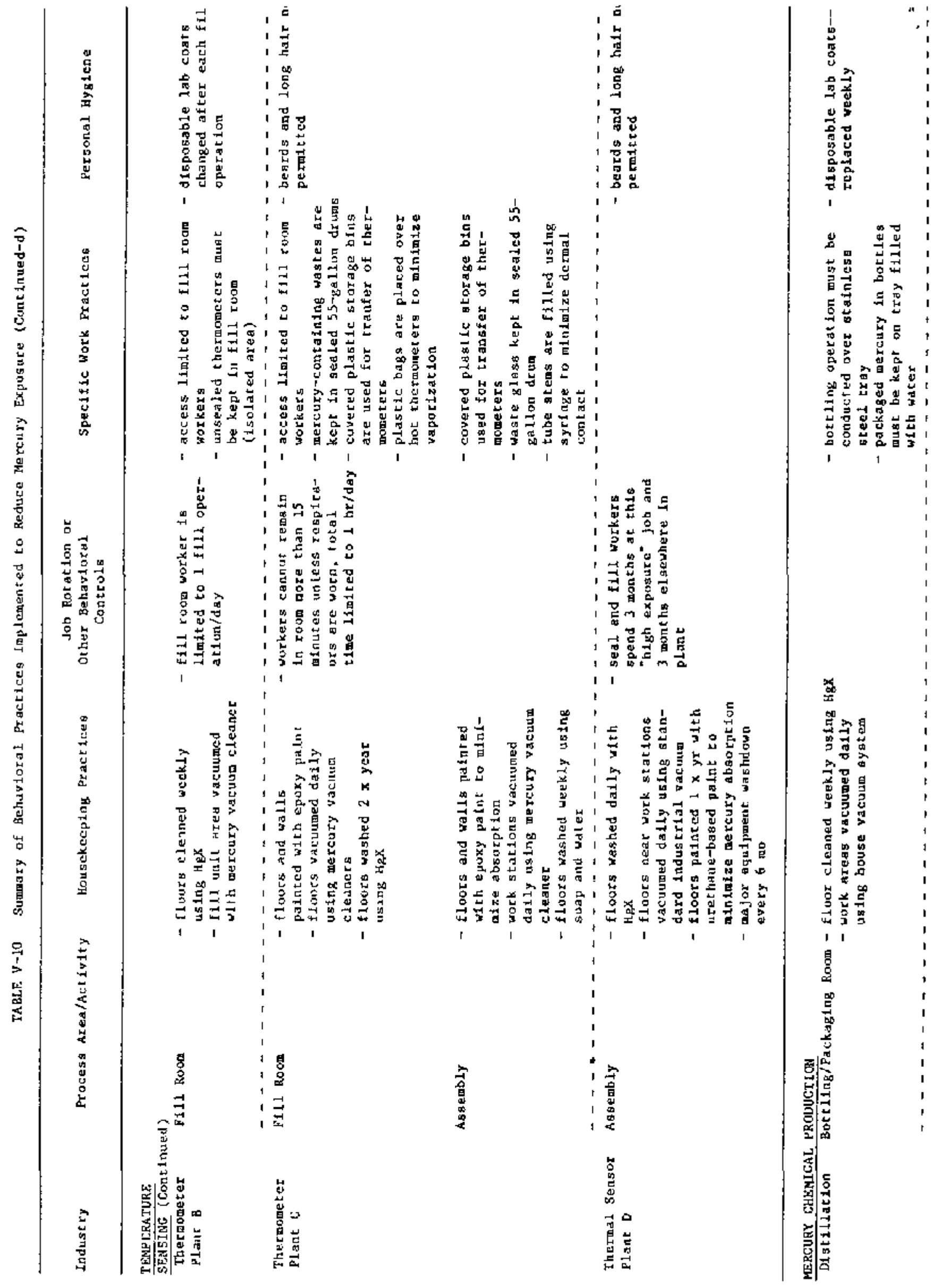




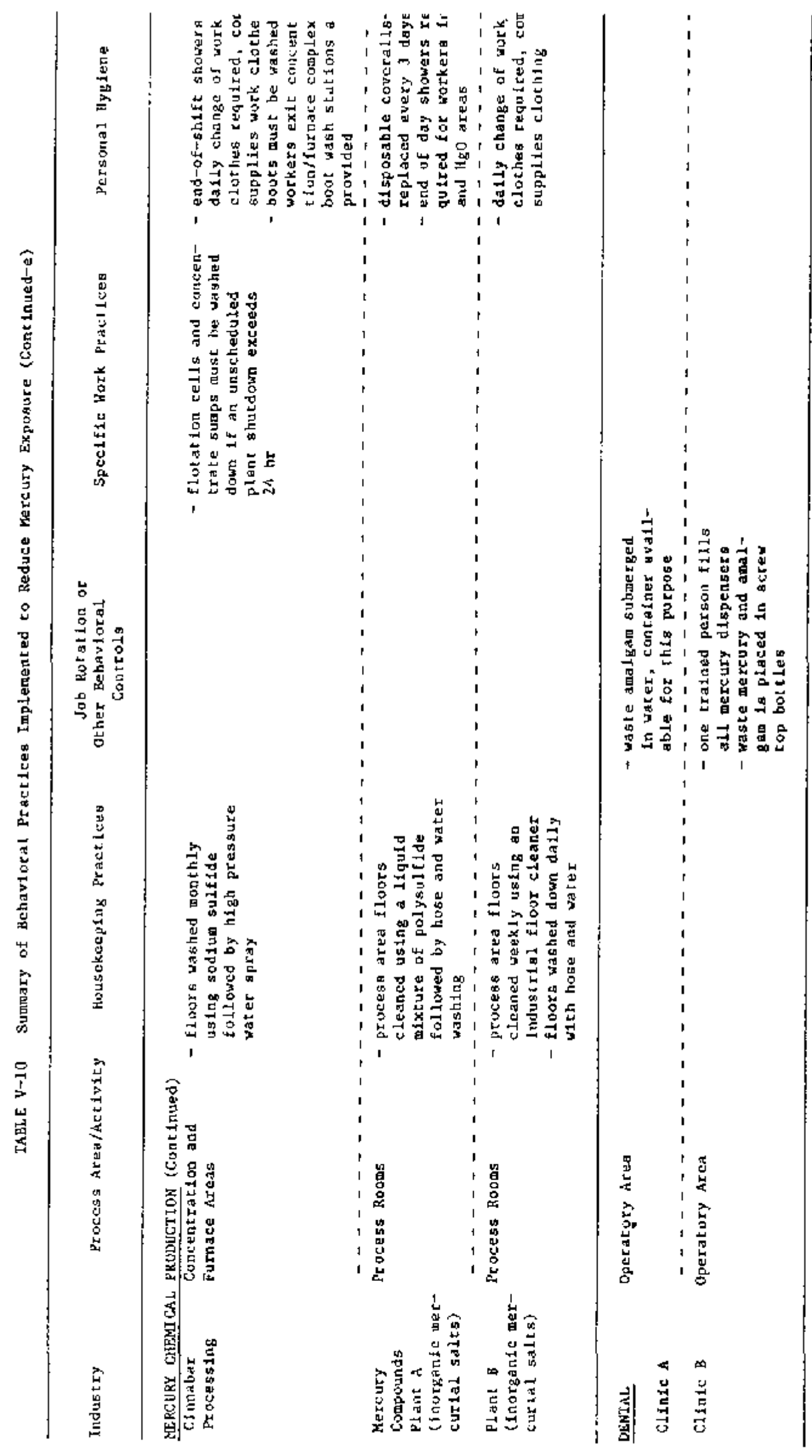


TABLE V-11

Summary of Mercury Decontaminant Applications

\begin{tabular}{|c|c|c|c|c|c|}
\hline \multirow[b]{2}{*}{ Decontaminant } & \multicolumn{5}{|c|}{ Form of Mercury } \\
\hline & $\mathrm{Hg}$ & $\mathrm{HgO}$ & PMA & $\begin{array}{l}\text { Mercuric } \\
\text { Sulfide }\end{array}$ & $\begin{array}{c}\mathrm{Hg}-\mathrm{Zn} \\
\text { Amal }{ }_{\text {g }} \text { am }\end{array}$ \\
\hline $\mathrm{HgX} \mathrm{X}^{\mathrm{R}}$ & * & $\star$ & * & - & * \\
\hline $\mathrm{Na}_{2} \mathrm{~s}$ & * & - & - & $\star$ & - \\
\hline Calctum polysulfide & * & * & * & - & - \\
\hline ZInc/sawdust & * & - & - & 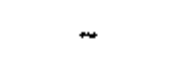 & - \\
\hline
\end{tabular}

Most of the plants surveyed had spf11 cleanup procedures 1 n the event of accidental spilla of both elemental and particulate forms of mercury. The procedures are simlar at most plants. Major elemente of all cieanup procedures used by plants are-

o The area around a spill is tmmediately vacuumed using a mercury vacuum Eleaner.

- The area is anspected for traces of mercury, a flashlight 18 often used to Illuminate elemental mercury.

- A mercury decontaminant (described in Table V-11) is applied and the area is mopped and/or hosed down with water.

- A mercury vapor detector may be used to monltor the area to determine if mercury vapor concentrations in the spill area are higher than normal. Spill cleanup procedures may be repeated based on monttoring results.

c. Painting Floors

In 7 of the 24 plants surveyed, floors were painted regularly (usually yearly) with dark-colored paint to aid in the detection of mercury drops and/or an epoxy/urethane sealant to munimize mercury penetration. plant representatives report fewer hougekeeping problems and lower mercury vapor concentrations following the application of floor coatings. 
Job rotation is a commonly practiced worker exposure control in mercuryusing industrles. It is practiced both as a routine preventive measure, in activitles where worker exposure cannot be reduced through englneering or other behavioral controls, and as a corrective measture when employees" biological montoring levels show unacceptably high concentrations of mercury. Corrective job rotation is discussed in the Blologlcal/Medical Monitoring section, p. 112 .

a. Preventive Job Rotation

Preventive job rotation is usually practiced in work areas that have a potentially high mercury vapor concentration. In the Fill Room of one mercury switch manufacturer, the welding machine operators alternate jobs so that only every other day is spent at the welding machine. In the filling area of a thermometer manufacturing plant, workers practice a rotating schedule in which 3 months are spent at a potentialiy high-exposure job (e.g., mercury ftlling) and 3 months are spent in another area of the plant. Reliance on job rotation as a preventive measure has the disadvantage of spreading worker exposure over a wider employee population.

b. Work Shift Change

At one chlor-alkali facilfty surveyed, plant representatives found that worker exposure to mercury vapor could be reduced (based on blological monitoring levels) by alterlng work hours so that work during the hot test part of the day could be avolded. Durang the summer season, and particularly during midday, the average mercury vapor concentrdtion in the cell roam was at its highest. Normal first-shift hours at the plant were from 7.30 a.m. to 4.00 p.m. During the hottest months of summer, the first-shift hours were changed so that workers started at 5:00 a.m. and finlshed at $2.00 \mathrm{p.m}$., when the second shift started.

\section{Work Practices}

The principal objectives of work practices used at most of the mercury-ustng plants studied were to mintmize the emission of mercury vapor and particulate, and to contain liquid wercury.

A common work practice is submerging mercury, and mercury-containing products and wastes, in containers of water. The water prevents direct vaporization of mercury to the atmosphere This practice is particularly valuable in industries that generate mercury-contaminated waste such as the thermometer industry (waste glass), switch industry (defective switches and parts), and the dental industry (waste amalgam).

Transfer, packaging, and bottling operations are frequently conducted over steel or plastic trays having ralsed edges to contaln stray drops or spllis.

At one chlor-alkall plant visited, spare equipment was used during maintenance activities to ayold working on hot process equipment. Mercury recycle pumps typtcally operate at a temperature in excess of $80 \mathrm{C}$ (176 F). 
Work procedures for mantenance activitles at one fluorescent lamp plant required that kraft paper be apread out at equipment repalr work stations to collect mercury and oil that may contain mercury. The paper was treated as hazardous waste and sent to an appropriate iandfil.

4. Personal Hygiene Practices

The personal hygtene practices listed in Table $V-10$ do not include the general practices comonly used at to most mercury-using industries surveyed. These practices are summarized as follows.

- Employees are encouraged to wash their hands often. Washing is mandatory before eating or smoking. Washing with soap is required because liquid mercury and some mercury components are difficult to remove from the skin.

- Smoking, eating, or drinklag are not permitted in or near process areas.

- Tobacco or food products are not allowed in process areas due to potential contamination probleas. Tobacco and food products can absorb mercury, whether in liquid or vapor state, and serve as a source of mercury intake.

The primary objective of the personal hygiene requirements of the mercury industries surveyed was to minimize employees' microenvironmental exposure. The most rigid personal hyglene requirements in effect were noted in the following andustries: battery manufacturing, chlor-alkali processing, cinnabar processing, and mercury compound manufacturing. In these industries, both end-of-shift showers and daily changes of clothing or the use of disposable clothing were mandatory to minimize mircroenvironmental exposure, in addition to general personal hyglene practices.

5. Education and Tralning

All of the aercury-using Industrles atudied instituted some form of employee education and tralning progran specific for mercury control. Most plants had informal training sessions for new employees. Several plants developed employee handbooks for this purpose. The objectives of the education and training programs are to.

- teach employee awareness of potential health hazards associated with the use of mercury.

- teach employees the housekeping practices, work practices, and personal hygiene practices needed to mintmize exposure.

Several audiovisual education tools are currently being used by mercuryusing industries as part of their employee orientation programs and periodic refresher training sessions. 
o A slide show package with sound track is used by one thermometer manufacturer. The package details potential health hazards and the importance of the microenvironment with regard to use of elemental mercury.

- A 30-minute film 15 used at a battery manufacturing plant. The f1ln detalls the physical properties of elemental mercury and the work practices used in the battery industry.

\section{PERSONAL PROTECTIVE EQUIPMENT AND CLOTHING}

Personal protective equipment was used at most of the plants surveyed. A summary of personal protective equipment used ts presented in Table V-12. of primary concern at most of the facilities was protection against inhalation of mercury vapor and particulate, and dermal or clathing contact with mercury.

\section{Respirators}

Currently there are no respirators approved by NIOSH for protection against inorganic mercury. However, respirators are widely used in mercury-using industries for nonroutine operations where control of mercury through engineering or other methods is not feastble. Certain mercurymusing industries rely on respirators as a primary control method because the desired plantwide workplace concentrations of mercury cannot be achieved. At the plants surveyed, the processes in which the use of respirators was most relied on for worker protection were the particulate handling operations of battery manufacturers and mercury chemical producers, and the distilling operations of mercury processors. A description of commonly used respirators follows.

a. Regptrator Descriptions

Specific for Mercury Vapor

3M 8707 Disposable Mercury Vapor Respirator (3M Company, St. Paul, MN) $A$ half-mask, sir-pur f fylng respirator containlng lodine-impregnated charcoal as the adsorption medium.

MSA Mersorb Respirator (Mine Safety Appliances Co., Pittsburgh, PA) A half-faceplece (Confo-II mode1) dual cartridge, alr-purdfying resplrator contalning (1) Mersorb (a proprletary sorbent) as the primary adsorption medium, and (2) a color indicator that changes from orange to dark brown when the filter medium has adsorbed a specifled amount of mercury vapor.

\section{Other Respırators}

Norton Highly Toxic Particulates Filter Respirator (Norton Safety Products, Cranstan RI)

$\bar{A}$ half-facepiece, dual cartridge, air-purifying respirator approved for respiratory protection agalnst dusts, fumes, and mists having a TWA concentration less than $0.05 \mathrm{mg} / \mathrm{m}^{3}$ (N1OSH approval No. TC-21C-152). 
TABLE $v-12$

Summary of Personal Protectlve Equipment Used

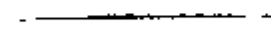

$-\quad--m-\longrightarrow$

$-\cdots$

[ridustry

Location and/or Activity

Primary Mercury

Exposure Concern

Personal Procective

Equipment and Clothing usad

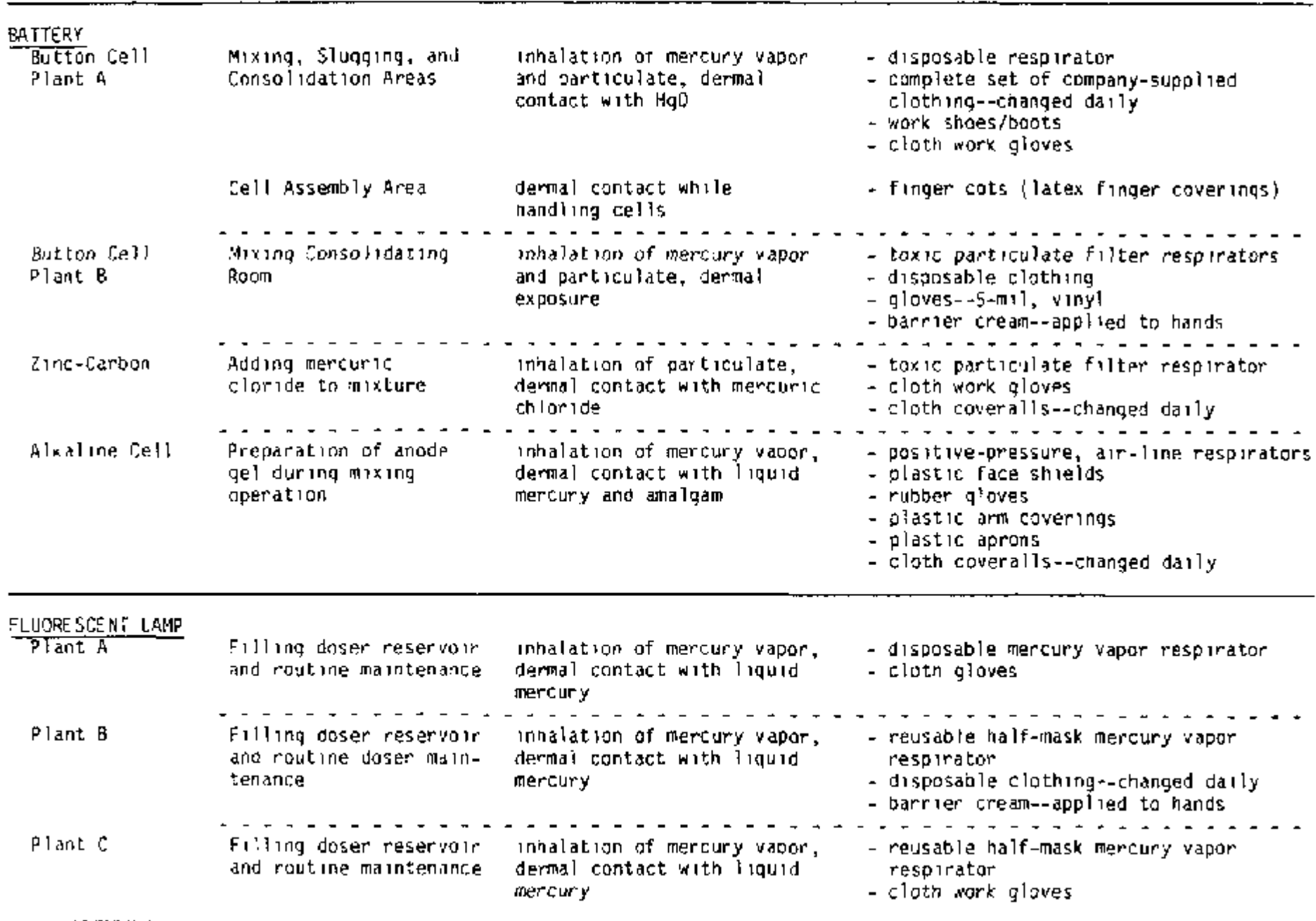


TABLE V-12

Summary of Personal Protect Ive Equiment Used (Continued-b)

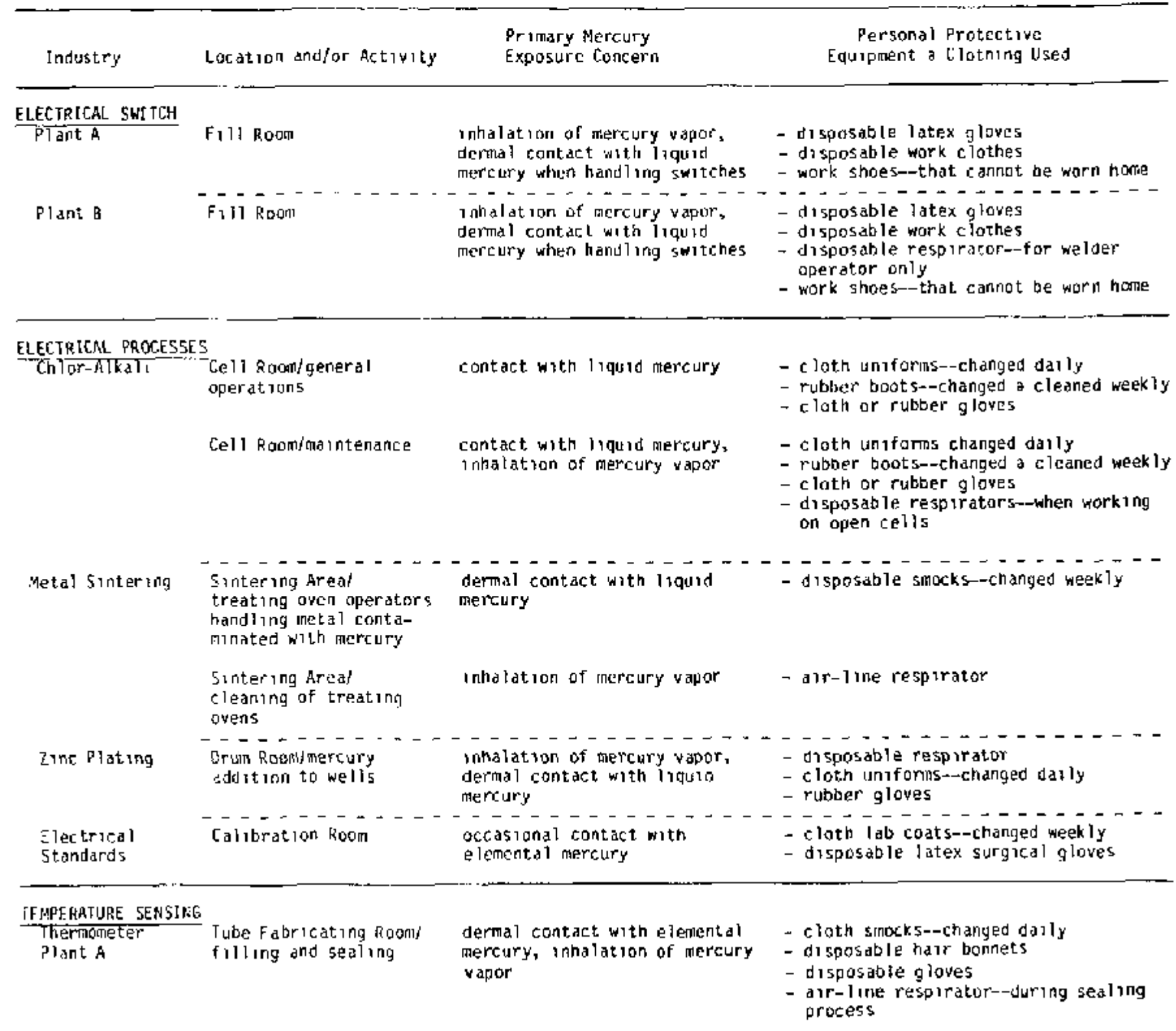


TABLE $\mathrm{V}-12$

Surmary of Personal Protective Equiment Used (Continued-c)

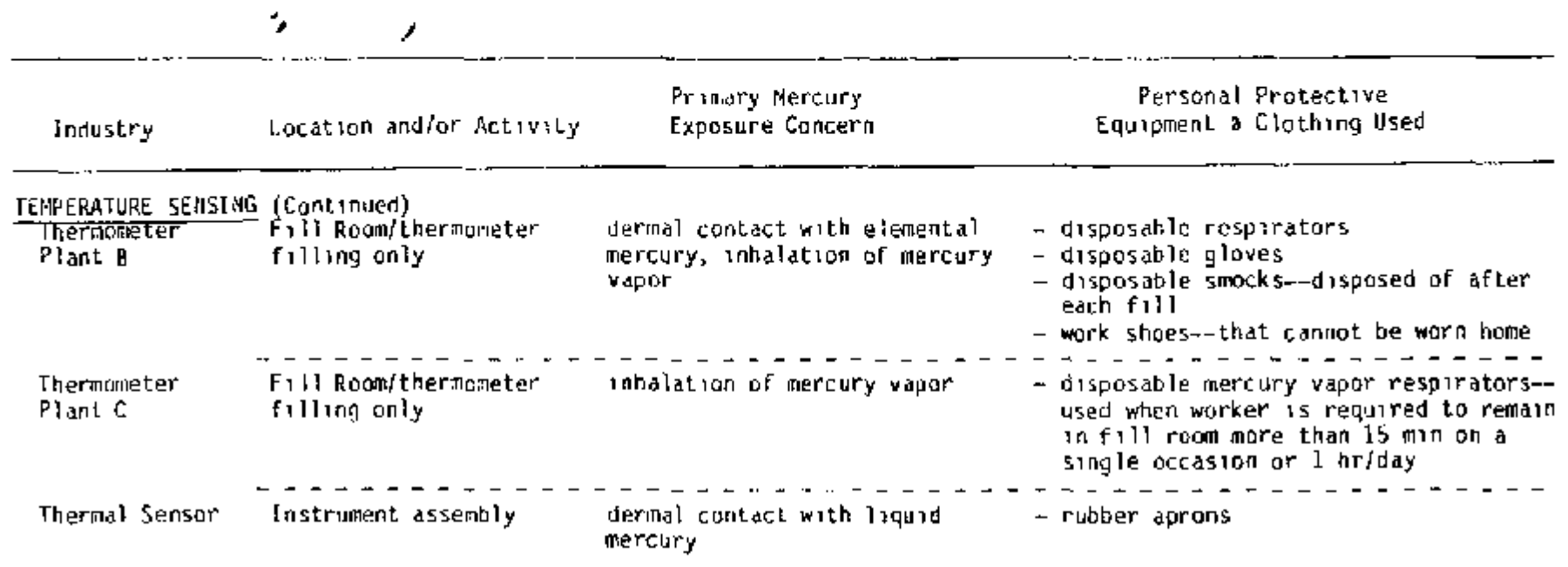

\begin{tabular}{|c|c|c|c|}
\hline Distillatyon & Dostillation dperations & $\begin{array}{l}\text { indalation of mercury vapor } \\
\text { and cont act with liguld } \\
\text { inercury }\end{array}$ & $\begin{array}{l}\text { - aisposable mercury vapor respirator } \\
\text { - disposable laboratory coat } \\
\text { - vinyl-codted chath gloves } \\
\text { - work shnes.-that cannot te worn away } \\
\text { from plant }\end{array}$ \\
\hline $\begin{array}{l}\text { Cinnabar } \\
\text { Processing }\end{array}$ & $\begin{array}{l}\text { Cancentrator and } \\
\text { Furnace Areas }\end{array}$ & $\begin{array}{l}\text { Inhalation of mercury vapor, } \\
\text { Jema i contact with mercury } \\
\text { and mercuric sulfide }\end{array}$ & $\begin{array}{l}\text { reus able half-f acepiece mercury vapor } \\
\text { respirotors } \\
\text { - rubber boots--cleaned dally } \\
\text { - rubber gloves--changed dally } \\
\text { - cloth coverallsm-changed dally }\end{array}$ \\
\hline $\begin{array}{l}\text { Merrury Compound } \\
\text { Plant A }\end{array}$ & Process Rocms & $\begin{array}{l}\text { inhalation of particulate } \\
\text { mercury compounds and mercury } \\
\text { vapor, dermal contact with } \\
\text { mercury compounds }\end{array}$ & $\begin{array}{l}\text { - full-facepiece, alr-purifying respira- } \\
\text { tor for mercury vapor and particulate } \\
\text { - disposable mercury yapor respirator } \\
\text { - disposable coveralis } \\
\text { - work boots }\end{array}$ \\
\hline ENTAL & Dperatory Arcas & mone & -none \\
\hline
\end{tabular}


A summary of the different types of respirators worn in mercurymusing industries 18 presented in Table v-13.

TABLE V-13

Summary of Resplrators

\begin{tabular}{|c|c|c|}
\hline $\begin{array}{l}\text { Type of } \\
\text { Respirator }\end{array}$ & Advantage & Disadvantage \\
\hline $\begin{array}{l}\text { Disposable } \\
\text { Mercury Vapor } \\
\text { Respirator }\end{array}$ & $\begin{array}{l}\text { Cleaning is } \\
\text { not needed }\end{array}$ & $\begin{array}{l}\text { More costly } \\
\text { than reusable } \\
\text { respirators }\end{array}$ \\
\hline & & $\begin{array}{l}\text { Generally do not } \\
\text { provide an air tight } \\
\text { seal around the face } \\
\text { causing leakage }\end{array}$ \\
\hline $\begin{array}{l}\text { Reusable } \\
\text { Mercury Vapor } \\
\text { Respirator }\end{array}$ & $\begin{array}{l}\text { Can be } \\
\text { individualiy } \\
\text { fit for each } \\
\text { employee }\end{array}$ & $\begin{array}{l}\text { Must be cleaned } \\
\text { daily or more } \\
\text { often due to con- } \\
\text { tamination problems }\end{array}$ \\
\hline $\begin{array}{l}\text { Toxic } \\
\text { Particulate } \\
\text { Filter } \\
\text { Resplrator }\end{array}$ & $\begin{array}{l}\text { Can be } \\
\text { individually } \\
\text { fit for each } \\
\text { etmployee }\end{array}$ & $\begin{array}{l}\text { Must be cleaned } \\
\text { daily or more } \\
\text { often due to con- } \\
\text { tamination problems }\end{array}$ \\
\hline
\end{tabular}

b. Respirator Applicatlons

In the depolarizer and slugger rooms of one mercury button cell manufacturer surveyed, disposable respirators are worn on a full-time basis. The processes in both rooms generate both particulate mercury (HgO) and mercury vapor. The plant has so far been unable to control the workplace concentrations of mercury (combined particulate and vapor) to below the OSHA PEL.

In the mercurlc oxide bagging operation at the same facllity, a scott supplied-a1r, pressure-demand, full-faceplece respirator is required. plant representatives feel that adequate control of particulate mercuric oxide in bagging operations $x$ s not feasible with the current local exhaust ventilation system because the material is so readily aerosolized. The plant will eventually eliminate the operation and replace it with an enclosed syatem. Until then, the use of the respirator is considered to be necessary to control worker exposure to within the allowable limits.

In the gel preparation (mercury-zinc amalgamation) room of an alkaline cell manufacturer surveyed workers wear positive-pressure, continuous mode, airline respirators (WIIson Products). These respirators are used to protect 
agalnst mercury vapor generated from gel handling operations. This operation is typically associated with TWA concentrations of mercury vapor in excess of the OSHA PEL.

In the concentrator and furnace areas of a cinnabar processing plant, MSA Mersorb Respirators (Comfo-II, half-facepiece, dual chemical cartridge) are used by all employees. This resplrator has a color indicator on the cartridge that changes from orange to brown when the filter media has absorbed a specified amount of mercury vapor (before breakthrough occurs), One advantage of the respirator is that a worker can easily monitor the color indicator on another worker's respirator. In areas of the plant where workplace concentrations of mercury vapor consistently exceed the MSHA and OSHA PEL, the cartridges generally last several weeks before needing to be replaced. This facility has relied on respirators since startup in 1975. Plant representatives report that the respirator use fs effective in minimizing worker exposure to mercury based on blological monitoring results. The average urine-mercury concentrations for operators at this facility was approximately $0.10 \mathrm{mg} / \mathrm{L}$ with a h1gh of $0.175 \mathrm{mg} / \mathrm{L}$ in 1981 . Malntenance workers generally have lower blologlcal monitoring results.

At a mercury compound production plant, resplrators are worn In al1 areas where mercury or mercury compounds are produced. Pulmosan Type CMH, No. 10792 full-facepiece, air-purlfying, cartridge respirators with hood are worn by workers when handling PMA and $\mathrm{HgO}$. These resplrators are intended to protect agalnst mercury vapor, which plant representatives have determined to be present in association with PMA and HgO production. They may also be effective in reducing exposure to PMA and Hgo particulate.

\section{Dther Protective Equipment}

Protective clothing, to minimize worker contact with inorganic mercury, was utilized in all of the Industries studied except for the dental industry. The most commonly used protective clothing included the following:

- Disposable uniforms or lab coats. Most of the disposable garments in use durang this study were made of Tyvek $R$ (DuPont, Wilmington, DE), which is a lightweight, spill-reststant, synthetic fabric.

- Cloth work clothes that are changed daily. Work uniforms at one chlor-alkali plant were made of 65 percent polyester and 35 percent cotton, a blend that plant representatives have determined through testing to be highly resistant to mercury penetration and absorption.

- Disposable gloves (various manufacturers). The gloves were made of varfous materials and thicknesses depending on the job application. Surgeon's gloves (5-mil latex) were used extensively at electrical switch, electrical standards, and thermometex manufacturera. The gloves were usually disposed of and replaced several times per day. 


\section{MONITORING CONTROL EFFECTIVENESS}

\section{Workplace Air Monftoring}

All but 4 af the 24 plants visited conducted routine afr monitoring to determine the airborne concentration of mercury. The most common sampling and analytical methads employed by industry are deacribed below:

a. Mercury Vapor Monitoring Direct Reading Instrunents

Commonly used Instruments and sampling methods are descrlbed below:

- Bacharach MV-2:

Principle of Operation - tltraviolet light at a specified wavelength is absorbed by mercury vapor. Absorption occurs in proportion to sampled concentrations.

Sensitivity. minimum detectable concentration $1 \mathrm{~s} 0.01 \mathrm{mg} / \mathrm{m}^{3}$.

Interferences. organic solvents.

- Jerome 401 Mercury Vapor Detector:

Principle of operation - absorption of mercury vapor on a gold film, thereby increasing 1ts resistance. Resistance is proportional to mass of mercury present in sampled air.

Sensitivity. minimum detectable concentration is $0.002 \mathrm{mg} / \mathrm{m}^{3}$.

Interferences. none reported.

This instrument can also be used as a continuous monttor.

Trme-Welghted Average Sampling

Passive Dosimecers. Passive dosineters or badges are available from several manufacturers including 3M Company and SKC Corporation. The badges contain a solid sorbent that adsorbs mercury vapor at a known rate proportional to amblent concentrations. These badges can be worn by employees or set out in an area during a full shift. The badges must be sent to the manufacturer for analysis.

Solid Sorbent Tubes: Solid sorbent tubes for the collection of mercury vapor are avaliable from varlous manufacturers including Mine Safety Appl1ances (MSA) (Ptttsburgh, PA), SKC Corporation (EIghty Four, PA) and Anatole Sipin Co., Inc. (New York, NY). The sorbent tubes constst of a proprietary solid sorbent medium (such as Hopcalite ${ }^{R}$ or Hydrar ${ }^{R}$ ) mounted in a glass tube. Samples are obtained using calibrated peraonal sampling pumps to draw alr through the sorbent tube. Samples obtained in this manner require analyses in a laboratory. The standard analytical method involves dissolving the meda in a mixture of nutric and hydrochloric actds. Analyses are completed using flameless atomic absorption (Rathje and Marcero 1976). 
A collection tube contalning a gold coll as the collection medtum is available for TWA sampling (from Jerome Instrument Corporation). Th1s system requires the use of a sampling pump. An advantage of this system is that onsite analysis can be conducted using the Jerome 401 Mercury Vapor Detector.

b. Particulate Mercury Monttoring

Because mercury vapor is often present in association with particulate inorganic compounds of mercury, a sampling method capable of collecting both forms should be used to determine the total inorganic mercury present. The sampling and analytical method widely used 1a a variation of NIOSH P\&CAM 175 (NIOSH 1975). Particulate mercury is collected on a glass fiber filter (avallable from Whatman Laboratory Products) or a tolxed cellulose ester acetate filter mounted in a cassette filter holder.

The filter cassette is located in front of the mercury vapor solid sorbent tube. Afr is drawn through the sampling train using a calibrated personal sampling pump. The filter is analyzed to determine the amount of particulate mercury present, and the sorbent tubes are analyzed to determine the amount of mercury vapor.

\section{Biological/Medical Monitoring}

Biological monitoring programs were in effect at all of the industries studied except for the dental industry. At many plants, blological monitorIng was under the direction of an occupational health phystcian and was part of a medical program designed to monttor and control worker exposure to mercury.

The program consists of periodic analyses of workers' urine or blood for both) to determine the concentration of mercury. The results of analyses are compared with. (1) recommended blological threshold limits (TABLES 14 and 15) or arbitrary threshold limits (set by plant representatives) and/or (2) previous blological monitoring results or results of coworkers to determine if blologlcal concentrations are 1ncreasing or decreasting. A note of caution should be mentloned, that is urine analysis for mercury often shows poor correlation between urinary mercury and signs and symptoms.

When a worker's biological concentration exceeds the "allowable 1imit," set by the plant, or increases significantly over previous sample concentratıons, a plant representative ugualiy examines that worker's job activities, work practices, and use of personal protective equipment to determine the cause of the elevated cancentration. At the same time, the worker may be removed from his/her present position to an area of the facllity with less potential for exposure to mercury. The worker is usually refinstated when his/her biological concentration falls below the threshold limit * 
TABLE V-14

Mercury Exposure Limlts and Required Action for the State of Massachusetts

\begin{tabular}{|c|c|c|}
\hline $\begin{array}{l}\text { Urine-Mercury } \\
\text { Cancentration } \\
\qquad(\mathrm{mg} / \mathrm{L})\end{array}$ & Condition & Action \\
\hline $0.00-0.05$ & No or insignificant exposure & $\begin{array}{l}\text { Repeat urinalysis } \\
\text { annually if exposure to } \\
\text { mercury continues. }\end{array}$ \\
\hline $0.05-0.15$ & Insignificant exposure & $\begin{array}{l}\text { Repeat urinalysis semi- } \\
\text { annually. }\end{array}$ \\
\hline $0.15-0.30$ & Signiflcant exposure & $\begin{array}{l}\text { Repeat urinalysts in } 30 \\
\text { days. }\end{array}$ \\
\hline $0.30-0.50$ & Definitely harmful exposure & $\begin{array}{l}\text { Conduct medical examin- } \\
\text { ation. Repeat urinalysis } \\
\text { again in } 2 \text { weeks. }\end{array}$ \\
\hline Over 0.50 & Hazardous condition & Remove from exposure. \\
\hline
\end{tabular}

TABLE V-15

Mercury Exposure Linlts for

the State of California

\begin{tabular}{|c|c|}
\hline $\begin{array}{l}\text { Urine-Mercury } \\
\text { Concentration } \\
\text { (mg/L) }\end{array}$ & Cond1tion \\
\hline $0.10-0.20$ & Warning level \\
\hline $0.21-0.30$ & $\begin{array}{l}\text { Hazardous level, remove from } \\
\text { further exposure }\end{array}$ \\
\hline 0.31 and Above & Significant exposure \\
\hline
\end{tabular}


Urinalyses were the basis of the monitoring programs at 20 of the 24 plants studied that used biological monttoring, blood analyses were relied on at the other four plants. Uxinalyses were preferred over blood analyses by nost plant representatives because sample collection was easier. At most of these plants, single volding samples were collected rather than 24-hour compoatte gamples. Although 24-hour composite samples were thought to be a better Indfcator of exposure, the problems associated with the collection of these samples made this method of sampling impractical.

The blological threshold 1 imit at which workers were removed from their pogitions varied considerably among the plants vibited. The urine-nercury lim1ts ranged from 0.05 to $0.50 \mathrm{~m} 1111 \mathrm{grams}$ per 11 ter (mg/L). At most plants, the $11 \mathrm{mit}$ was $0.30 \mathrm{mg} / \mathrm{L}$ or lower. The "concern $11 \mathrm{mit}$ " for repeating urinalyses ranged from 0.025 to $0.30 \mathrm{mg} / \mathrm{L}$. At plants where blood analyseg were the basis of biological monttoring, the mercury concentration at which workers were removed frow their jobs was $10 \mathrm{ug} / 100$ ml of blood.

Although blological monttoring progtams are designed to monttor worker exposure and workplace control effectiveness, several mercury-using 1ndustries have reported an additional benefit of the program. By naking employees aware of their results in the periodic sampling (urlne or blood concentrations of mercury), they become more aware of activities that result in elevated biological samples and usually take corrective action on their own to reduce exposure. 
VI. CONCLUSIONS

\section{GENERAI, COMNENTS}

1. The control of worker exposure to mercury at the facilities studied was the result of an integrated control appraach that included engineering contro1s, behavioral controls, personal protection, and monttoring programs applied as necessary. The combined control approach was used in every facility studied, with the exception of dental clinfcs.

2. Good housekeeping, sound work practlces, and use of smooth, Impermeable materials on floors and work surfaces are sometimes sufficient controls to mantain worker exposure to mercury below the allowable limit. Th1s is particularly true of operations involving the use of small amounte of mercury at or below normal room temperature such as dental facilities and standards manufacturers.

3. NIOSH or plant reported area and personal mercury a1r samples taken during this study were generally above the OSHA PEL of $0.1 \mathrm{mg} / \mathrm{m}^{3}$ in the following processes/industries:

- button cell cathode production (particulate) and anode gel preparation $\mathrm{tn}$ battery manufacturing (vapor)

a furnace and concentrator areas in cinnabar processing (vapor)

- spray drying and reactor/druming areas of a PMA manufacturer (vapor).

For these operations the full-time use of resplrators was required to minimize exposures until appropriate control measures could be effected.

4. NIOSH area and personal mercury air samples taken during this study were generally above the NLOSH recommended level of $0.05 \mathrm{mg} / \mathrm{m}^{3}$ but belaw the OSHA PEL of $0.1 \mathrm{mg} / \mathrm{m}^{3}$ in the following processeg/industries.

- button cell cathode productlon- slugging (vapor) 1n a battery plant

- conventional mercury addition process (vapor) of a fluorescent lanp manufacturer

o fill room (vapor), next to the fill units, in one thermoneter plant

- spray drying operator (vapor) of a PMA manufacturer

5. Area and personal samples which were taken during this study, other than those reported in $\$ 3$ and $\$ 4$, were below the NIOSH recommended level of $0.05 \mathrm{mg} / \mathrm{m}^{3}$. 


\section{SPECIFIC CONTROLS}

1. The use of the mercury "pill" in the fluorescent lamp manufacturing process results in lower workplace mercury vapor concentrations and eliminates routine mercury "doser" maintenance that is assoctated with direct contact with liquid mercury.

2. Ventilated work stations can control mercury vapor emission during elevated temperature operations (e.g., "burning of $f$ " and sealing thermometers).

3. Collector ring contacts or stmilar electrical contact devices can elimtnate the need for mercury electrical contacts in certain electroplating processes. These devices, if applied to other electroplating operations, could reduce the number of workers exposed to mercury.

4. Preenclosed dental capsules are probably more convenient in dental operating procedures, however, their effectiveness in reducing mercury vapor concentrations was not demonstrated in this study.

5. Water-soluble plastic bags containing mercury compounds, used for charging batch chemical mixing operattons, may have value in reducing or eliminating worker exposure. However, problems associated with shipping (e.g., accidental contact with water in transit or storage) may require additional protective packaging.

6. Enclosed liquid mercury addition/transfer systems driven by air pressure have been shown to work well in several facflitles. These systems can be applied in modified form to almost all mercury-manufacturing industries, thus ellminating manual handling steps.

7. Liquid mercury can be effectively contained at work stations/benches having the following characteristics.

- Work surface made of stainless steel

- Stannless steel drannage troughs along the front of the work surface. The troughs should be sloped so that mercury can drain to a collection bottle. A lip along the other sldes of the surface prevents thercury from spilling onto the floor.

- Alcernately, if work activities permit, a worktable made of stainless steel having a screened or grated surface over a sloped sink is effective. The sink should be sloped to allow mercury to drain into a collection bottle. A level of water should be maintained in the sink to further minimize mercury vaporization.

Examples of effective work stations are shown in Figures VI-1 and VI-2.

8. Floors that are sealed with epoxy coating, vinyl sheets, or other impermeable coverings are highly effective in minimizing housekeepting problems and facilitating cleanup of mercury spills. 
9. The Plexuglas-ventilated machine enclosures seen at particulategenerating processes were not effective in controlling particulate concentrations to within allowable limits even though ventilation capacity was increased. Insuffictent control is caused by repeated worker access to the machine while opening the enclosure to make adjustments, etc. The solution to this problem is in locating important access/adjustment points outside the enclosure.

10. Temperature control was probably the wost effective englneering control for reducing general workplace air concentrations of mercury vapor. Applying temperature controls in many instances may make it possible to relax or eliminate other more costly controls, as long as spills are prevented.

11. Pura-\$1vR mercury adsorption units effectively cemove mexcury from exhaust aifstreams. This type of unt is beneficlal for mercury removal service in high-mercury-content (approximately $10 \mathrm{mg} / \mathrm{m}^{3}$ ) alrstreams.

12. The Torit mercury filter unit was found to be approximately 75 percent efficlent in removing mercury in a rectrculation system. However, the housekeeping problems associated with the use of this unt makes its application impractical. 


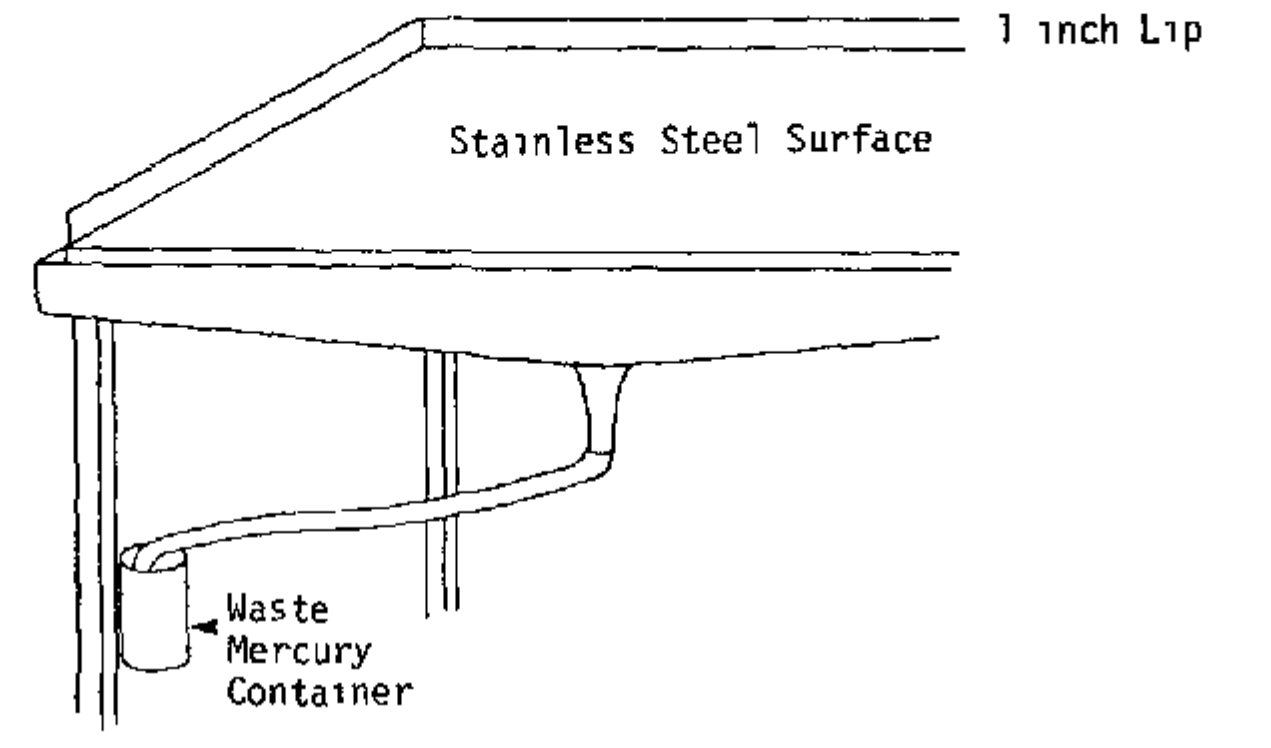

Figure VI-1 Work Station with Drainage Trough

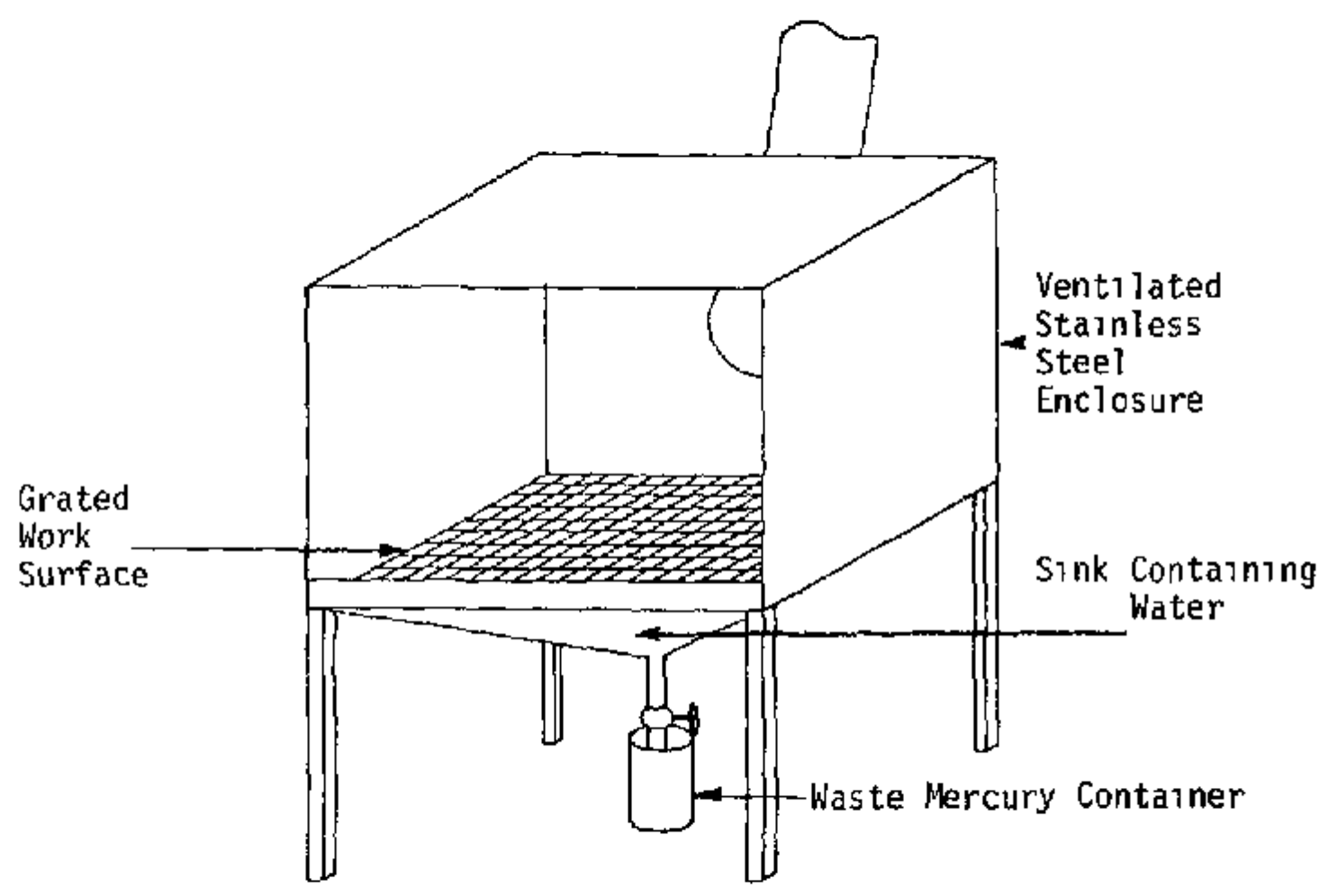

Figure VI-2. Ventilated Work Station with Grated Surface 
VII. RECOMMENDATIONS

1. Mercury should be purchased in contadners sized for particular process needs, these containers should adapt readily to enclosed addition systems. Currently, most industries using mercury are buying 76-pound flasks and nanually transferring mercury to the system.

2. Investigation into degigning completely enclosed methods of mercury particulate transfer should continue. Inadequacies in all of the sollds matertals handing systems were observed at the factlities studfed.

3. Vacuum cleaner equipped w1th mercury traps and carbon filters should be used both for routine cleaning and for cleanup of spills. Use of conventional vacuum cleaners results in high mercury vapor concentrations.

4. Plant alr recirculation systems are effective in renoving mercury and can be cost effective depending on geographical location. If these systems are to be used, a filter/air handler inspection program should be instituted to determine if the system is performing optimally. The program should include monitoring filter effectiveness, determining alrflow characteristics, and determining the quality of the reintroduced air.

5. The use of preenclosed dental capsules is recomended, although they did not result in a detectable lowering of mercury vapor concentrations in the dental facilities studied. However, they eliminate a mercury handling step and the associated potential for accidental spills.

6. The "mercury pi11" addition system observed at a fluorescent lamp plant should be used at other fluorescent lamp anduacturing facilities, the system should be further modified so that 1 t can be used in the mercury swftch manufacturing industry.

7. Workers who are 1nvolved in mercury particulate handling operations should continue to wear respirators until effective control methads have been developed. A siudy to develop control methods is recommended.

8. Workers should continue to weat respirators when Involved with distilling operations or other operations where elemental mercury is handled at temperatures above room temperature and local exhaust is impractical. New alr exhaust systems should be designed and/or installed to eliminate worker exposure and dependence on respirators.

9. Mercury decontamination cleaning aids should be routinely used in general plant housekeeping programs and in the cleanup of spllis. The use of mercury decontaminants may not be necessary if stringent housekeeping measures using conventional industrial cleaners are fastituted. 
10. Dafly clothing changes or disposable clothing should be requited for all workers who routinely contact mercury. D1sposable clothing has the advantage of eliminating laundering of contaminated clothing but requires proper disposal.

11. Because mercury to difficult to remove from the skin, washing hands thoroughly before breaks and at the end of shtfts should be mandatory.

12. Disposable gloves should be worn whenever possible for workers who handle mercury or mercury-containing items.

13. Although job rotation on a routine basis can reduce an employee's exposure to mercury to allowable limits, it has the disadvantage of spreading mercury exposures over a wide population, Consequently, job rotation should be used only as an interlm measure until other control methods are applied to reduce exposures to acceptable levela.

14. Biological monltoring should be conducted for all exposed workers. Evaluation of group biological monftoring results provides more information on the extent of exposure and effectiveness of controls than do individual evaluations.

15. Care should be taken that job-related dectstons on mercury control are based on sound data. No less than two determinations should be made, and these should be no less than 48 hours apart. The final decision should be made by a phyaician after examining the worker. Exposure or health effects cannot be determined by the laboratory results alone. Individuals can experfence very different health effects at the same biological mercury levels. An effective monttoring program must integrate medical determinatlons tnto its decisionmaking process so that actions are taken based on all of the avallable information.

16. Workplace area and personal monttoring should be conducted to determine employee exposure and control effectiveness. Although the currently avallable direct reading instruments for the measurement of mercury vapor ure sensitive and accurate, TWA breathing zone determinations are a more rellable indicator of worker exposure.

17. At many of the factlities visited ventilation systems were destgned on a "number of air changes per hour" basts. This is inadequate for areas where mercury is used. Monftoring programs should be instituted at these locations to measure area and personal mercury concentrations on a regular basis, because of the potential for localized high exposures. 
REFERENCES

Criteria for a Recomended Standard.... Occupational Exposure to Inorganic Mercury. Publication No. (NIOSH) HSM 73-11024. Cincimnati, US Dept of Health, Education, and Welfare, Public Health Service, Center for Disease Control, National Institute for Occupational Safety and Health, 1973,129 pp

Discussion with Leonard J. Goldwater, M.D., Duke University Medical Center

Hammond PB, Beliles $R$ Metals, In Doull $J$, Klaassen $K$, Amdur M (eds.): Toxicology The Bastc Science of Poisons. New York, McMtilan Publishing Co., Inc., 1980, pp 421-428

Mercury in Air--Measurements Research Branch Method No. P\&CAM 175, in NIOSH Manual of Analytical Methods, ed 2, DHEW (NIOSH) Publication No. 79-141. Clnctnnat1, US Dept of Health, Education, and Welfare, Public Health Service, Center for Disease Control, National Institute for occupational Safety and Health, 1979, vol 5, pp 175-1 to 175-17

Mineral Facts and Problems, 1980, Bullet1n No. 650. US Dept of the Intertor, Bureau of Mines, 1980

Occupational Health Guideline for Inorganfc Mercury, DHHS(NIOSH) PubIIcation No. 81-123, January, 1981.

Rathje AO, Marcero DH: Improved Hopcallte procedure for the determination of mercury vapor in air by flameless atomic absorption. Am Ind Hyg Assoc J, May 1976, pp 311-314

Sanders HJ, Gardiner WC, Wood JL: Mercury cell chlorfne and caustic. Ind \& Engr Chem 45:(9) 1824-1835, 1953

Stopford W, Bundy SD, Goldwater LJ, Bfttlkofer JA: Microenvironmental exposure to mercury vapor. Am Ind Hyg Assoc J 39. 378-384, 1978

Zenz, C., Ed1tor Occupational Mediclne: Principles and Practical Applications, Chicago, Year Book Medical Publishers, Inc., 1975, pP. $668-676$. 


\section{APPENDIX \\ SAMPLING AND EVALUATION METHODS}

This appendix presents the methods for air sampling and analysis used during this study to measure workplace concentrations of mercury, as well as the methods of engineering evaluation used to determine the effectiveness of control measures.

\section{A. AIR SAMPLING AND ANALYSES}

A1r samples were collected to determine the alrborne concentrations of mercury.

\section{TWA Samples}

a. Personal sampling -- Personal alr sampling was conducted to evaluate the exposure of a worker to airborne mercury from various sources. Where respiratory protection was used, samples were collected outside of the respirator. The results of these samples were compared with the allowable limit to determine the effectiveness of the control measures uged. Sample perlods usually included a full shift.

b. Area sampling -- Area sampling was conducted to determine the effectiveness of the controls used to reduce amblent concentrations of mercury in the workplace. Samples were collected at fixed locations. Sample tlme varied but usually lasted the duration of the shift.

Both personal and area mercury vapor concentrations were obtained using personal monitoring pumps (MSA Model $\mathrm{C}-200$ ) to draw alr through Hopcalite solld sorbent tubes. For peraonal samples, the tube was attached to the ahirt collar or lapel of the employee. The flow rates, set at $75 \mathrm{ml}$ of air per munute, were determfined both before and after sampling using a buret (soapbubble meter). Analyser of samples were conducted using flameless atomic absorption (Rathje and Marcero 1976).

Particulate mercury samples vere obtalned usling a high-flow personal sampling pump (MSA Model $S$ or G) to draw air through glasa microfiber ftlter (Whatman Laboratory Products) mounted in 37-mm cassettes. The flow rates, set at 2.0 liters of air per minute, were determined both before and after samplang using a buret. Analyses of samples for total mercury were conducted using flameless atomic absorption.

\section{Grab Samples}

A direct reading instrument that provides an instantaneous measurement of mexcury vapor was used to determine area and breathing zone concentrations. A Jerome Model 401 Mercury Vapor Detector, with a sensitivity of 0.001 $\mathrm{mg} / \mathrm{m}^{3}$ and a range of $0.001-0.50 \mathrm{mg} / \mathrm{m}^{3}$, was used to collect grab samples. 


\section{B. AIRFLOW MEASUREMENTS}

The effectiveness of local exhaust ventilation (LEV) systems and dilution ventilation systems was determined in part by the measurement of alr veloc1ties to calculate airflows. Face velacities at exhaust or supply openings were measured using a velometer (Alnor Serfes 6000 or thermoanemometer). Duct velocities were determined using a pitot tube and inclined manometer, The contaminant capture range of some LEV systews was measured using a smoke generation tube. 